\title{
Reclaiming the Projects: Reinterpreting Social Housing \\ Through the Revitalization of the Robert F. Wagner Houses
}

Vanessa Ann Haddock

Submitted to the Faculty of Graduate and Postdoctoral Affairs

in Partial Fulfillment of the Requirements for the Degree of

Master of Architecture

in

M ARCH Professional

Carleton University

Ottawa, Ontario

(c) 2014

Vanessa Haddock 


\section{Reclaiming the Projects}

REINTERPRETING SOCIAL HOUSING THROUGH THE REVITALIZATION OF

THE ROBERT F. WAGNER HOUSES 


\section{VANESSA ANN HADDOCK}

COPYRIGHT @ 2014 OTTAWA

THESIS SUBMITTED TO AZRIEL SCHOOL OF ARCHITECTURE AND URBANISM, CARLETON UNIVERSTTY, OTTAWA ONTARIO, CANADA

IN PARTIAL FULFILMENT OF THE REQUIREMENTS FOR THE DEGREE OF MASTER OF ARCHITECTURE (M.ARCH PROFESSIONAL) 
I would like to thank those who supported me on this journey towards achieving this level of learning.

my advisor Inderbir Riar, for his instrumental guidance,

my parents, for their endless love and confirmation,

my friends, for their inventive diversions,

and Leo, for ensuring my safety in the streets of Harlem. 
Throughout the history of modern housing, a collective way of living has been central to architecture and urbanism. It has been a fundamental concept utilized in the development of metropolitan cities to accommodate the constant growth of the population desiring to reside within the city center. Looking closely at New York City, the following chapters will be a guide through the advancements in housing ideologies based on social behaviours of the time. Beginning in the mid-nineteenth century, New York City fell into a state of flux with large growth in population due to immigrants from overseas and elsewhere in the United States seeking the opportunities of a more fruitful life. Since then the city has been a testing ground for concepts of the densification of living originating from many key thinkers around the world. Success and failure, in this respect, refer not only to the original goals, to solve the housing crisis provoked by population growth and provide modern standards for the whole society, but equally to the shifting significance of mass housing within the respective societies and their perception by architect, politicians, and inhabitants. ${ }^{1}$ Specific case studies vital to political and social conduct on the increasing population density, demographic changes, and division of social classes will be explored to gain a general understanding of the characteristics of housing in New York City throughout history. 
A B S T R A C T

INTRODUCTION

CHAPTER ONE EXPOSING THE PAST: NEW YORK CITY AND HOUSING

EP. 1. HOUSING THE POOR: URBAN TENEMENTS IN NEW YORK

EP. 2

APARTMENT LIFE: STUYVESANT FLATS

EP. 3

MODERN MIDDLE-CLASS MIGRATION: SUMMYSIDE GARDENS

EP. 4.

POST WWII HIGH-RISES: TOWERS-IN-THE-PARK

THE CITY: DIVIDED BY SOCIAL CLASS 


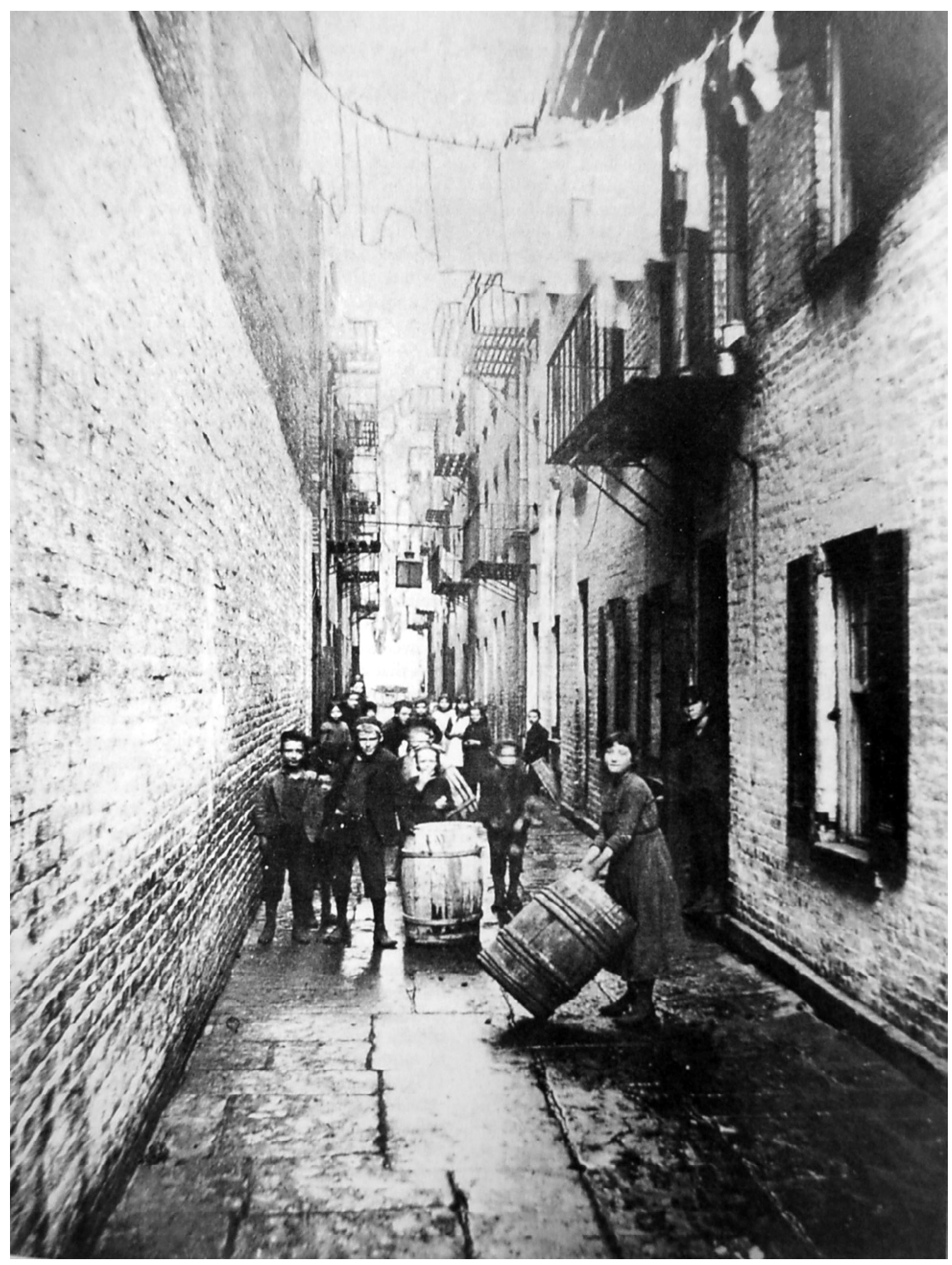

PLACES CALLED HOME

Gotham Court (1851), 36-38 Cherry Street. View c. 1890 Riis. MCNY 
Since the turn of the twentieth century, modernist mass housing has been understood as a synonym to the term Social Housing with the affiliation to such idioms as low-income dwellings, the projects, affordable living, and public housing. A question is raised about the appropriateness of these terms and, in fact, the possibilities they hold. The objective of this thesis is to remove the stigmas associated and define the term 'Social', and its related idioms, in respect to the dwelling and its social and political conditioning by investigating alternative strategies to this model. The following chapters will explore the development of housing throughout history, in New York City, as well as survey key case studies of housing typologies which were crucial to the growth of the city itself. The reader will be introduced to important individuals who became fundamental to the advancement of these housing typologies to accommodate the quickly emerging population of New York City since the mid-nineteenth century.

The thesis aims to develop speculative and innovative approaches to an example of one of these design standards in the revitalization of the Robert F. Wagner Houses located in Harlem, New York. A series of programmatic elements will intervene on the tower-in-the-park site and become a networking of community and family for its residents. The design will propose a prototypical approach that will enhance the social relationship of the communities residing in complexes such as the Robert F. Wagner Houses. 


\section{chapter one}

\section{EXPOSING THE PAST:}

\section{NEW YORK CITY AND HOUSING}

Throughout the 1870s, 1880s, and especially the 1890s, an influx of new and larger population transformed every American metropolis. This was an era of change in housing from the single family house to collective living in order to accommodate the quickly growing population. A concept that had been implemented abroad in many European cities, Western society adopted the seemingly effective scheme of mass housing to uplift the social and economic stand point of American metropolitan development. This collective way of living became a norm, but not without political concerns, due to issues involving standards of social class and moral beliefs on propriety. The realization of the tenement and apartment house, both referring to dwellings designed to accommodate three or more separate sets of tenants under a single roof, became the designated housing option for the affluent and the impoverished population desiring to live within the urban fabric of the city for reasons such as social status for the affluent population and proximity to the labour force for the working class. Both models of dense urban living, suffering from technological and hygienic restraints of the time, lent themselves to the standards of the social class in which they accommodated with respects to quality of living. 


\section{ep. 1. HOUSING THE POOR:}

URBAN TENEMENTS IN NEW YORK

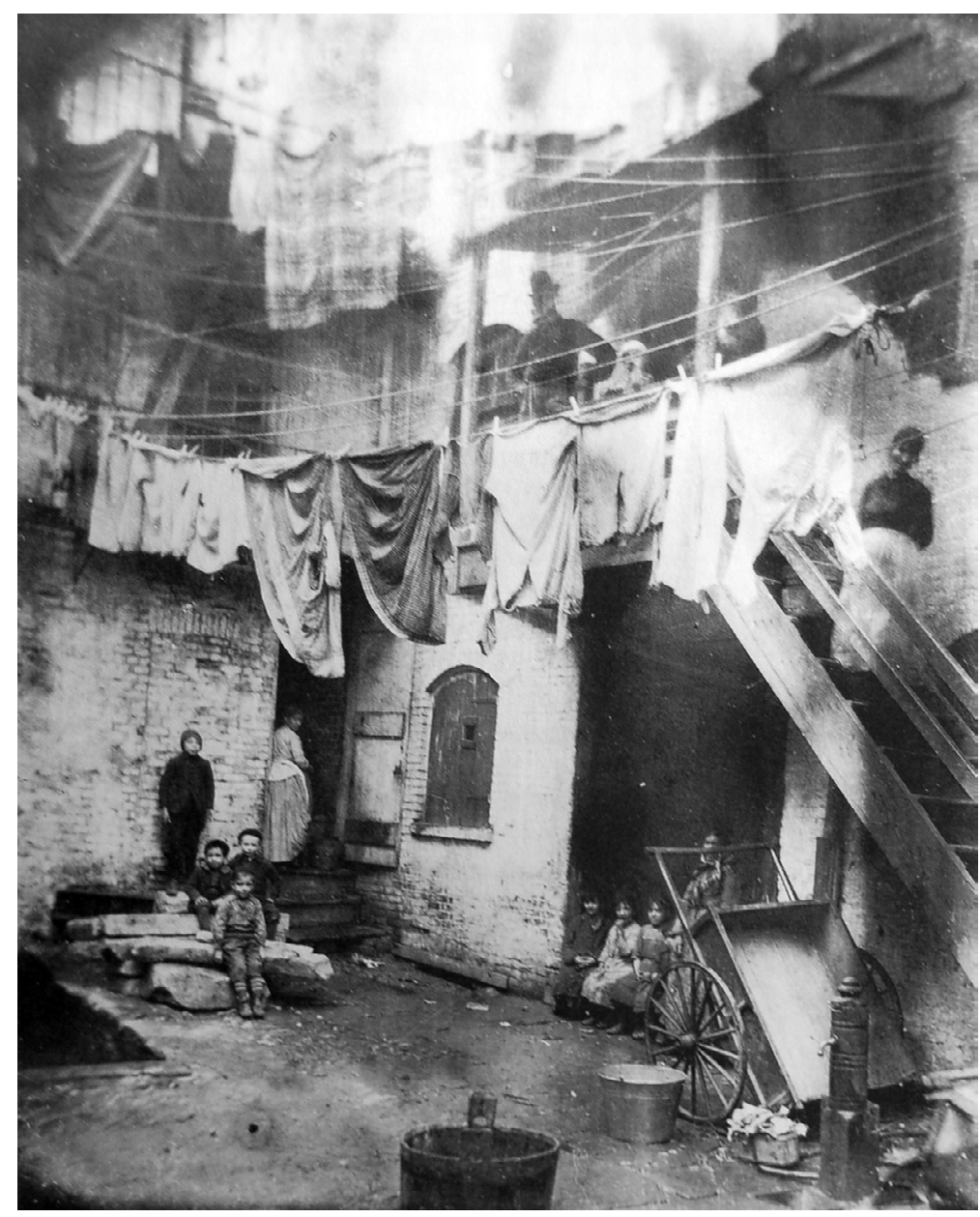

- Cheek to jowl tenement living in New York City, c. 1900. Photo by Jacob Riis
Beginning in the late eighteenth century, New York experienced an economic expansion that transformed the quality and character of artisan labor. In the trades industry, workers performed many tasks in strictly subdivided routines based on piece rates. Often, jobbers contracted out special tasks to independent producers who, in turn, reduced rates and wages even further to make a profit. These economic changes brought a dramatic influx of immigrants looking for opportunities in American culture. As manufacturing expanded, the demand for un-skilled and semi-skilled labor increased. ${ }^{2}$ These immigrants had to reside in the inner city where small businesses and factories hired on a daily basis. Manhattan was divided; granting acreage on its southern tip to mercantile interests involved in shipping, and north of the port (just north of Wall Street) property was distributed as town lots to settlers. Due to the unfavorably low income of the average immigrant family, they were urged to live in the destitute conditions of tenement houses. The environment itself could demoralize and even physically destroy its residents; the abysmal poverty, disease, and disconnect of the inner city were attributed to the overcrowded tenement dwelling. ${ }^{3}$ As immigrant population increased, so did the number of tenements and the percentage of New Yorkers living in them. The living conditions that the tenement residents were subject to were extremely undesirable due to hygienic constraints of adequate lavatory facilities as well as a lack of ventilation, natural lighting, and privacy. In many cases, families of five or six were restrained to two room units, which were accessible only through crossing rooms occupied by other families, because of 


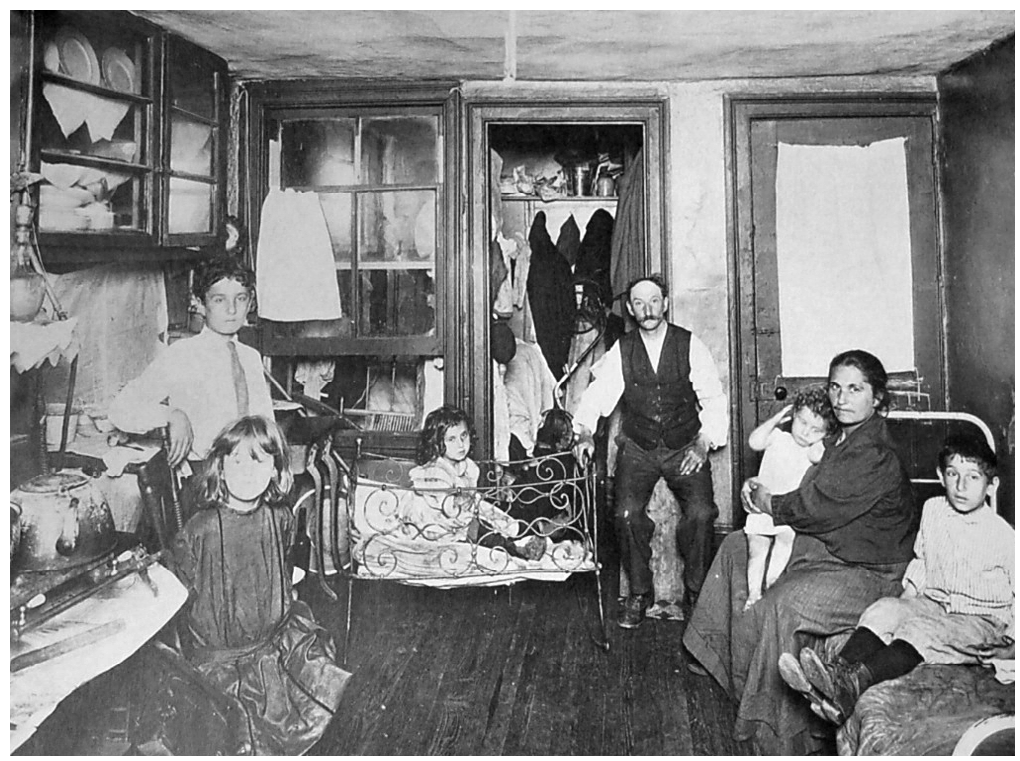

Windowless interior room of a railroad tenement, photo by Jesse Tarbox Beals in 1910 the absence of communal hallways. Also the multi-functional rooms provided a strong base for bad hygiene and breading of disease.

The concentrations of tenement houses in American cities, such as similar neighborhoods in England were called "Rookeries", a word derived from medieval English slang for a group of thieves. Although London's rookeries were made up of flimsy sheds and ill-constructed hovels they also contained what once had been fine, large houses, latterly falling into decay and filled with criminals, prostitutes, loungers and beggars. Architectural historian Robin Evans describes,

In a crowded room every detail of daily life was made public and familiar. Things which modesty and propriety would keep apart - cooking, undressing, sleeping, working, washing, bathing, defecating, urinating, fornicating, dying, and giving birth took place in close proximity. In rooms empty of furniture but 'never free of inmates' where neither comfort nor innocence could flourish, indeed it was frequently supposed that only crime could grow out of this pooling of raw experience. ${ }^{4}$

In the second half of the nineteenth century, New York City was home to communities of such standards. Neglected and over-crowded tenements proliferated in the city's dense, ethnic enclaves, producing some of the most stunning images of nineteenth century urban poverty. ${ }^{5}$ A well-known example a community built around similar conditions was Five Points, just below Canal Street, which housed predominantly Irish and African American residents. 


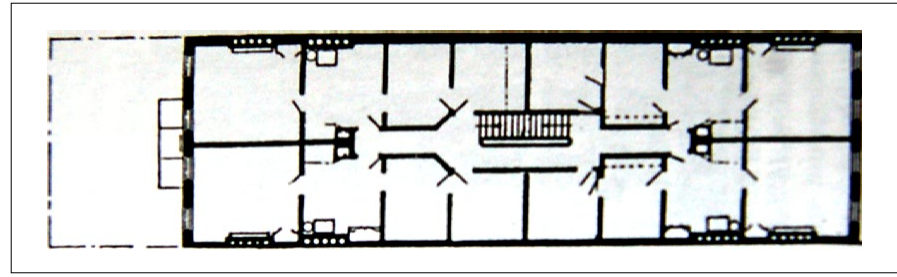

- Typical Railroad tenement, c. 1855. Plan. SAH. CU

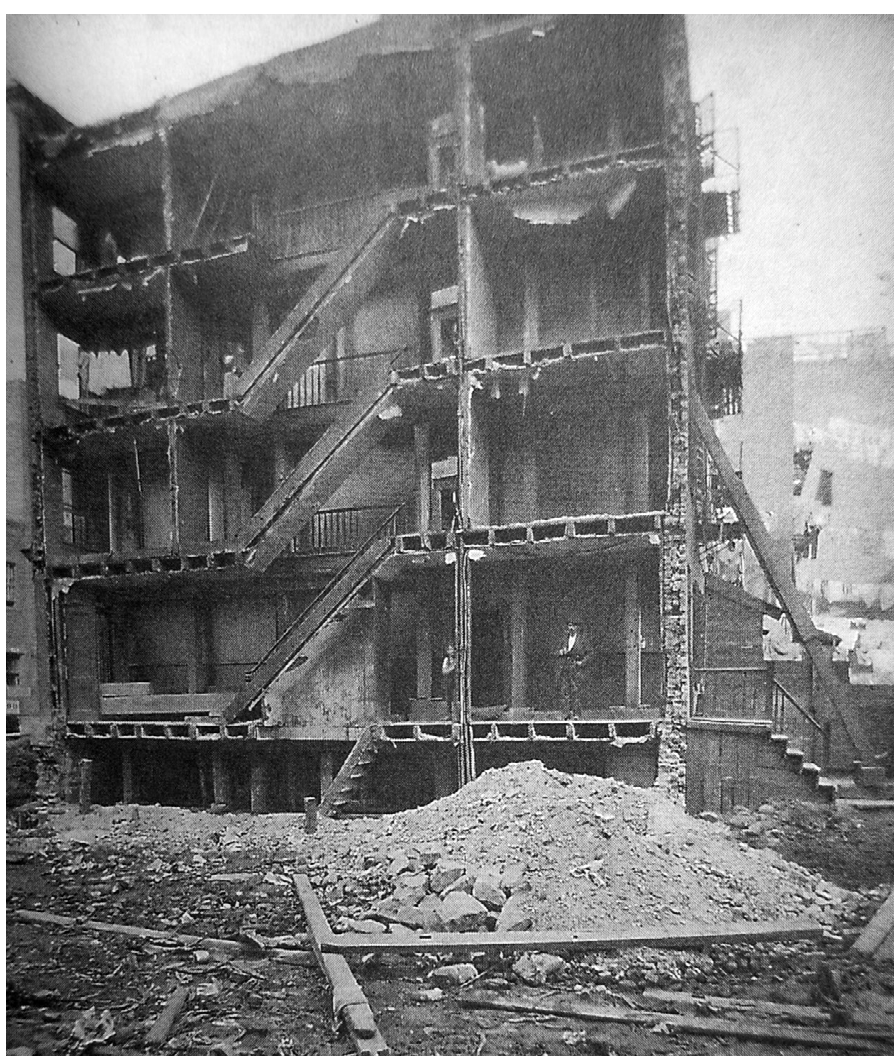

- A true "cross section" of a Railroad tenement at a demolition site circa 1903-1904 provides a rare view of the central stairwell, the sinks, and plumbing and gives some scale as to the size of the small rooms facing the front and back
As a New York City housing type, the tenement was designed to contain a maximum density of inhabitants with the constraints of the 25-by-100-foot building lot system, set forth by the design of the city's gridiron organization. The 25 foot width of the tenement design was depicted by structural constraints such as maximum spans of wooden floor joists. The heights of the buildings were five or six stories and were often older structures retrofitted into tenements by adding floors to the already shaky structures or filling the rear yards with additional housing. ${ }^{6}$ Many neighborhoods or blocks were converted to tenement housing with no requirements for minimum space or ventilation. One of the earlier evolutions of the New York tenement house was the mid-nineteenth-century Railroad tenement named because of the organization of the rooms was similar to that of a train car. In this model, the rear yards were almost always eliminated to accommodate more housing. Only the rooms facing the street received natural light and ventilation, leaving the interior rooms with neither. To house as many families as possible, landlords and owners routinely subdivided living room and bedroom into closet-sized, windowless compartments. Each side of the building would have abutting structures on both sides, making it very difficult to rectify the issue. Former Mayor of New York City, Philip Hone, made a statement in 1860 stating, "it is a shameful manner of constructing houses for renting and I have noticed especially in the eastern section of the city, blocks of new buildings so tightly built that they could not stand alone, and like drunken men, require the support of each other to keep from falling." ${ }^{7}$

The New York state legislature passed a law in 1866 defining standards for building construction in New York City. A year later, the first comprehensive housing law, the Tenement House Act of 1867, marked 


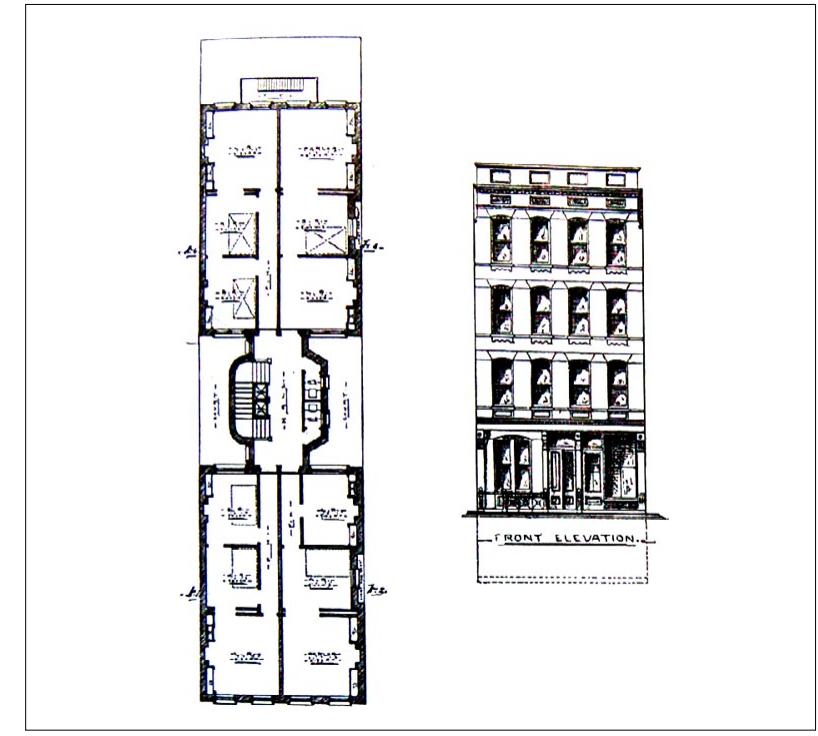

Glumber and Sanitary Engineer's model tenement competition, 1878. James E. Ware, winning entry. Second-floor plan and elevation. PSE. CU

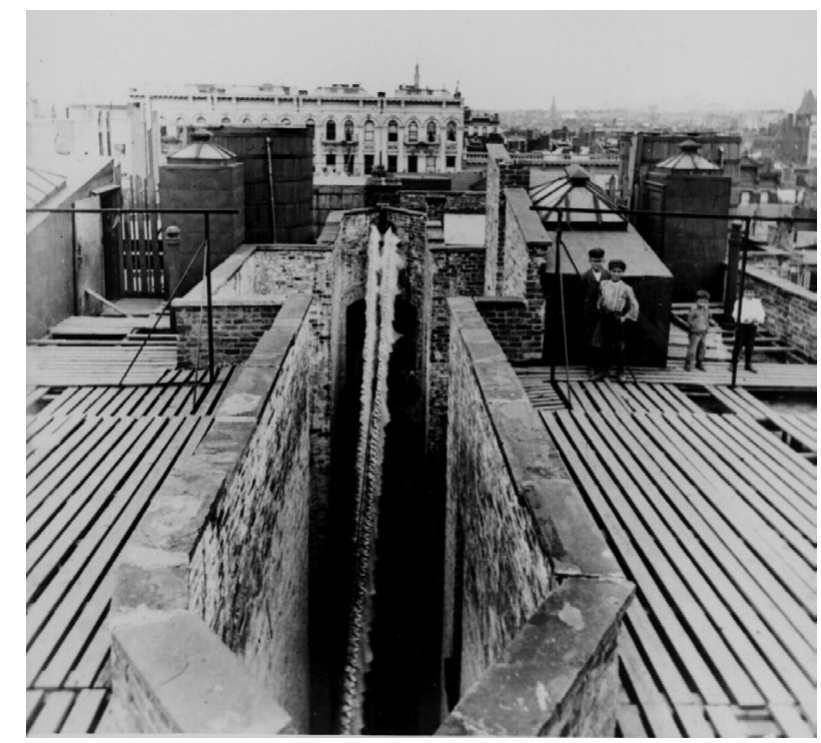

Photo by Jacob Riis of an air shaft in a Dumbbell tenement the beginning of the state's long involvement in regulating low-cost housing design. This act required one water closet for every twenty tenants, while school sinks and many types of cellar dwellings were outlawed. It also created mandatory provisions for fire escapes for non-fireproof structures. For the most part, these new laws proved ineffective. Thus in 1879, there was a design contest sponsored to review tenement designs that could rectify the unsuccessful implications of the Tenement House Act of 1867, as well as improve ventilation conditions within the buildings. Contestant James Ware submitted the winning design of the tenement model, called the Dumbbell Tenement, proposing a solution to the ventilation issue with twenty-eight inch wide and fifty to sixty feet long indentations on either side, breaking up the solid block. The efforts of this competition led to the passage of the Tenement House Act of $1879 .{ }^{8}$ New requirements set building lot coverage at 65 percent, set minimum distances between front and rear buildings, and set minimum standards concerning windows and cubic feet per occupant. Therefore the construction of the dumbbell tenement became the norm between 1979 and the turn of the century. In reality, what this newly adopted tenement model had done was create another problem within the design. The air shafts, which were the key design characteristic, rarely met their purpose of letting natural light into interior rooms because of their significant depth. As well, the ventilation coming from the shafts seldom seemed adequate due to the waste thrown down by tenants and left to rot.

In 1894, the Tenement House Committee stressed the strict enforcement of statutes that set minimum space requirements for each person living in the tenements. They felt that this would solve the problem of overcrowding but they were not considering the problem 
from the immigrant's perspective. By limiting the number of tenants, immigrant families could no longer take in borders to supplement their meager income. Therefore, although conditions within certain the tenements improved, tenants could no longer afford to live in them. With nowhere else to go, families were simply displaced to other overcrowded tenements.

Through minimum standards, improved tenements could save poor children, educate immigrants about American values and citizenship, and protect workers' families from disintegration. By focusing so strongly upon the tenement environment and its structural and sanitary defects reformers failed to perceive that the structures themselves did not necessarily create overcrowding, exorbitant rents, or run-down conditions. Landlords and, to a lesser extent, tenants made these choices based on market conditions and on the legal and social dynamics of the landlord-tenant relationship. ${ }^{9}$

\section{ep. 2. APARTMENTLIFE: STUYVESANT FLATS}

The collective way of living was the option for affluent population desiring to live within the urban fabric of the city centers as well. The housing model was called the apartment house and differed somewhat from the dismal conditions of the tenement houses. A tenement consisted of three or more families living independently under one roof, while an apartment house contained collective services for all its residents. ${ }^{10}$ Often centralized amenities were available in the 
basement or on the top floors such as kitchens and laundry facilities. Staff would prepare food that could be sent to lobby-level cafés, or to the residents' private dining room. People were enthusiastic about apartment house technology and services as well as its potential in recognizing certain aspects of American domesticity. The creation of the apartment elevator was seen as an American technological advance that "democratized" the housing model because it did away with the hierarchical structure of the European residences, in which poor families were demoted to the basement and the upper floors, while the wealthy families climbed only few stairs. The use of the elevators in American buildings made every floor equally accessible.

The early apartment houses were called "French flats", after the similar model of housing used in France at the time, evoking a cosmopolitan social life; the glamorous influence of the continent, and the slightly risqué practice of living in close proximity to one's neighbor. ${ }^{11}$ Large, comfortable buildings of several stories with rooms providing attractive accommodations for each family were common in Paris and other French cities, and interest in multi-dwelling for the "respectable" middle-class families had been growing in the United States for some time. The American Institute of Architects was in need of a good model for multifamily housing in New York and the sustainability of the French design caught their interest. The idea of several families living in the same building was commonly associated, in the United States, with the congested and unsanitary conditions of the tenements, into which foreign immigrants were crowding. Therefore, at first the prejudice of "respectable" people against this mode of living was strong, for to move into multi-family housing seemed to mean a lowering of one's social position. Before this mode 


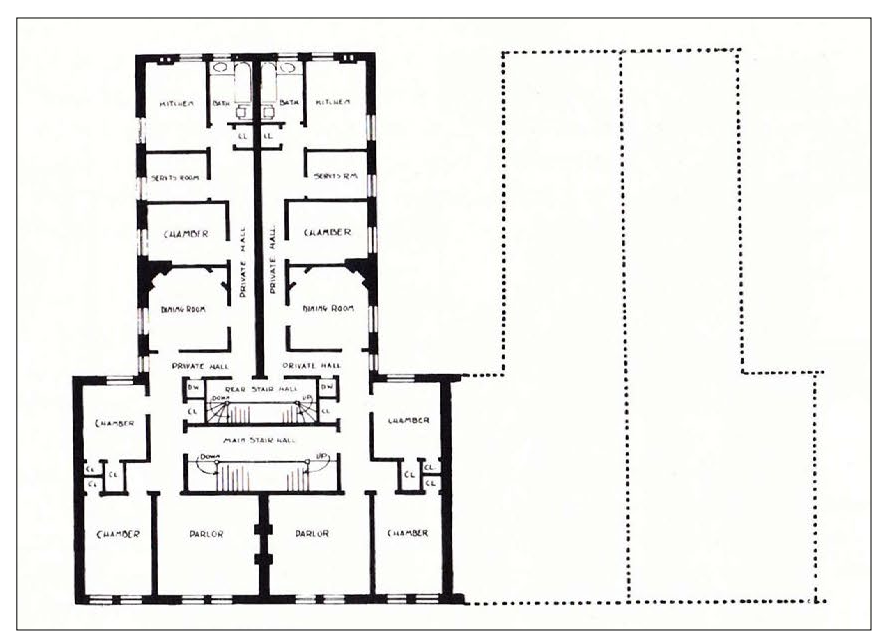

- Plan of typical floor, Stuyvessant Flats. From Architectural Record ( July 1901)

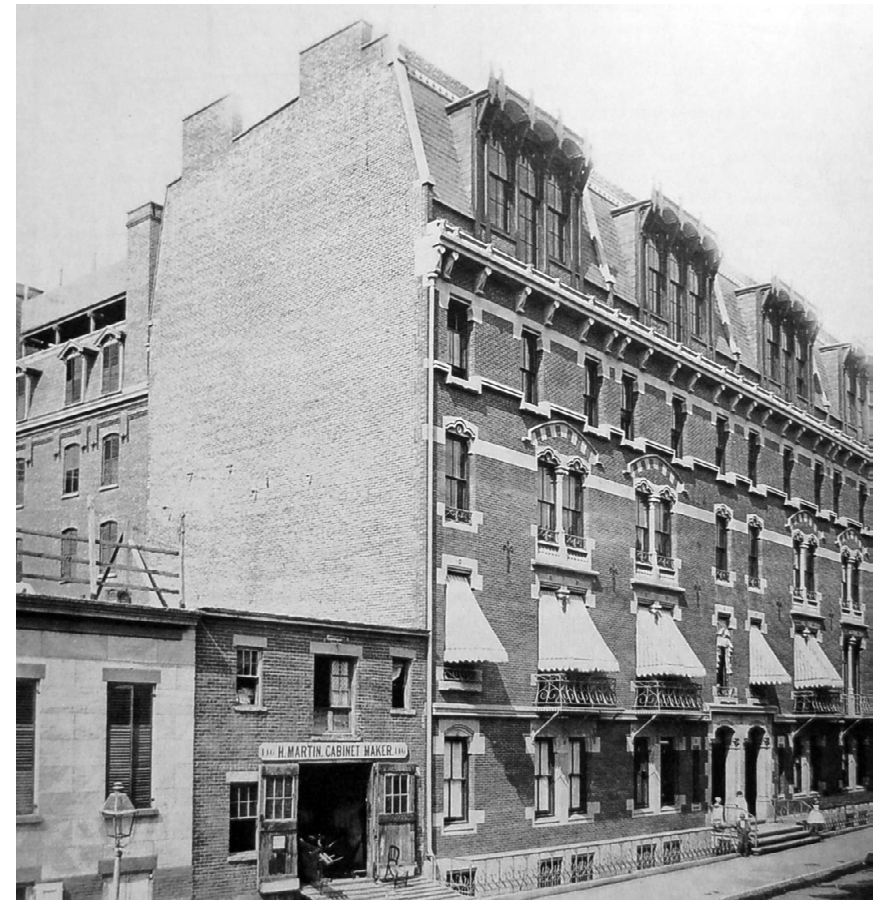

View to the southeast. Stuyvesant Flats, 142 East Eighteenth Street. Richard Morris Hunt, 1869-1870. The Octagon, AAF. of housing could become widely accepted it was necessary to make the multi-family dwelling respectable, or better yet, fashionable. ${ }^{12}$

The concept was not carried out in the United States until Rutherford Stuyvesant ventured to try the new idea in 1869. The Stuyvesant Flats was the first American apartment house, and it established an important precedent for a whole new class of structures in American cities. The design was done by architect Richard Morris Hunt and was constructed between May 1869 and February 1870 at 142 East $18^{\text {th }}$ Street, in Manhattan. The design consisted of two identical five-story buildings occupying two 25-by-100-foot gridiron lots, not unlike that of most tenement houses. Each section was served by a broad staircase rising from a spacious, Romanesque-style lobby. Fronting on Eighteenth Street for a little over 112 feet, the main part of the building extended 37 feet in depth, while two wings, each 36 feet wide and 50 feet deep, reached to the rear, with inner courts on both sides providing light and ventilation to the rooms away from the street. To the rear of the main staircase in each section, a separate service staircase provided access to the upper floors for servants and tradesmen.

The building relied on a certain French architectural elegance to attract a specific class of residents. A visible characteristic of this effort was the Mansard roofs. The widespread use of this style of roofing in the mid nineteenth century France was because the top floor of a residential apartment, under the roof, would not be taxed as an additional floor. This did not hold case in American law but was adopted because the architectural profession viewed the Parisian École des Beau-Arts the supreme authority on beauty. ${ }^{13}$ Another positive effect of this choice of roofline was that it made the buildings appear to be shorter, lessening the dramatic difference from the single family house. The Stuyvesant 


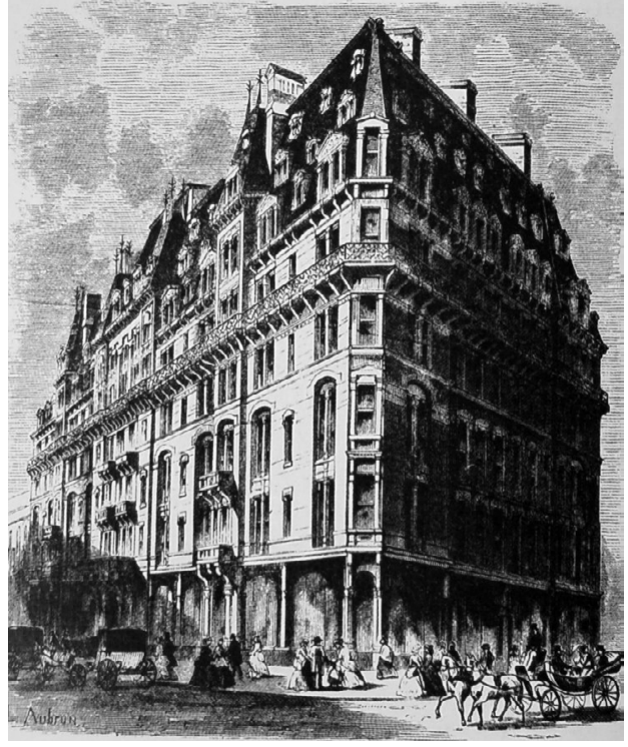

Richard M. Hunt. Stevens House, (1871) Broadway and 26 th Street; the first tal apartment house to fully reflect new technological breakthroughs, including steam elevator

ep. 3
Flats had considerable impact on building practices in New York City, for the apartment as a mode of living quickly caught on. The immediate demand for suites in the building made builders realize that "French flats" could be profitable investments, and within a short time many new apartment houses were constructed and many existing structures were converted into apartments. Most of the apartments following the Stuyvesant Flats were variations of Hunt's design, though with the addition of elevators in later years.

The floor plans of the early apartment houses resembled that of the dumbbell tenements. The buildings suffered from the same ventilation issues and lack of direct sunlight. This lack of attention to certain details was due to the desire for grandeur and the emphasis put on it. During the 1880's, the efforts to ameliorate the unfortunate conditions of tenement housing benefitted more the apartment houses because of greater funding and care towards quality of life for the affluent population.

\section{MODERN MIDDLE-CLASS MIGRATION:}

SUNNYSIDE GARDENS

By the turn of the century, Manhattan's population was growing at impeccable speeds. The rich and the poor were increasing with most of Manhattans population living in tenements while the remainder occupied the extravagant brownstones. With a shortage of affordable housing options for the great middle class they began to make use of the economically viable land of the suburbs. Improvements in mass transportation encouraged the middle class to move to the periphery 
such as Bronx, Brooklyn and Queens. Peripheral settlements would offer their residents space, open air, sunlight, in sharp comparison with the dreary squalor of the industrial city center.

In 1898 Ebenezer Howard brought this idea to a head with his Tomorrow: A Peaceful Path to Real Reform (revised in 1902 as Garden Cities of Tomorrow) ${ }^{14}$ Howard detailed an urban model of constellation of ideal forms built as satellites to an existing metropolis, such as London. Author Robert Fishman described how Howard created the basic plan for his ideal community:

He envisaged his Garden City as a tightly organized urban center for 30,000 inhabitants, surrounded by a perpetual "green belt" of farms and parks. Within the city there would be both quiet residential neighborhoods and facilities for a full range of commercial, industrial, and cultural activities. Howard did not conceive the garden city as a specialized "satellite town" perpetually serving some great metropolis. Rather, he foresaw the great cities of his time shrinking to insignificance as their people desert them for a new way of life in a decentralized society. No longer would a single metropolis dominate a whole region or even a whole nation. Nor would the palatial edifices and giant organizations of the big city continue to rule modern society. Instead, the urban population would be distributed amongst hundreds of Garden Cities whose small scale diversity of functions embody a world in which the little man 


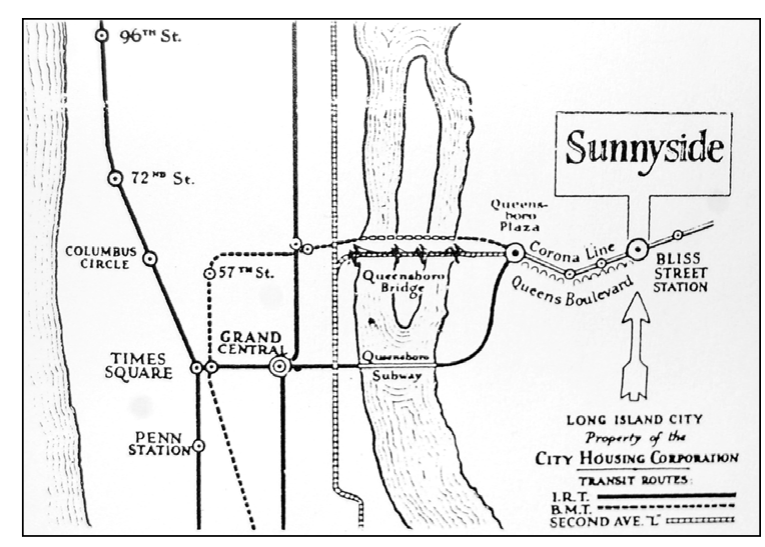

Whe location of Sunnyside Gardens in relation to Manhattan and the New York transit system

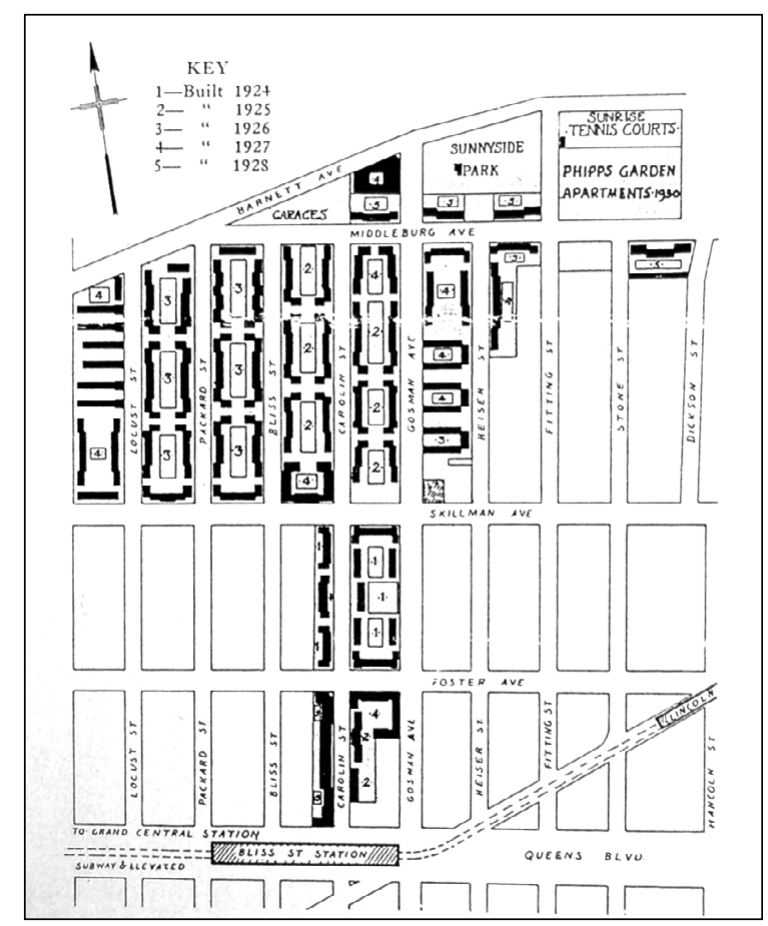

Dhysical development within the boundaries of Sunnyside Gardens between 1924 and 1928 has finally won out. ${ }^{15}$

Sunnyside Gardens, in Northwestern Queens, was a manifestation of the ideas developed by the Regional Planning Association of America and the first attempt to design a Garden City in America. It was based on many ideas developed by Ebenezer Howard, in an attempt to find a solution to the severe shortage of low-cost urban housing and the related problem of slums and overcrowding in American cities. It was constructed between 1924 and 1928, and was a creation of architects Clarence Stein and Henry Wright and the Housing Corporation led by developer Alexander Bing. The RPAA not only regarded this as a problem due to an inadequate amount of housing but more importantly a problem related to social and community values. This is where they came to the conclusion that city planning and regional planning go hand in hand and the regional distribution of population could be connected in ameliorating the situation. The objective was to create high quality residential design at a reduced cost; a goal they believed was achievable through thorough planning and organization. ${ }^{16}$

Sunnyside Gardens adapted Ebenezer Howard's architectural ideas of his Garden City by covering only covering 28 percent of the land, allowing for a large amount of open space in order to integrate elements of rural and urban life. Construction of the community was divided into three phases, each corresponding with the distribution of particular housing types. Phase one began in 1924 and construction followed through into the following year. Over 350 dwelling units were constructed, primarily in long blocks on a part of the site nearest to the public transit, as well as neighborhood school and stores. A total of three basic housing types were constructed in the first phase, with nine variations across those types. Sizes ranged from 


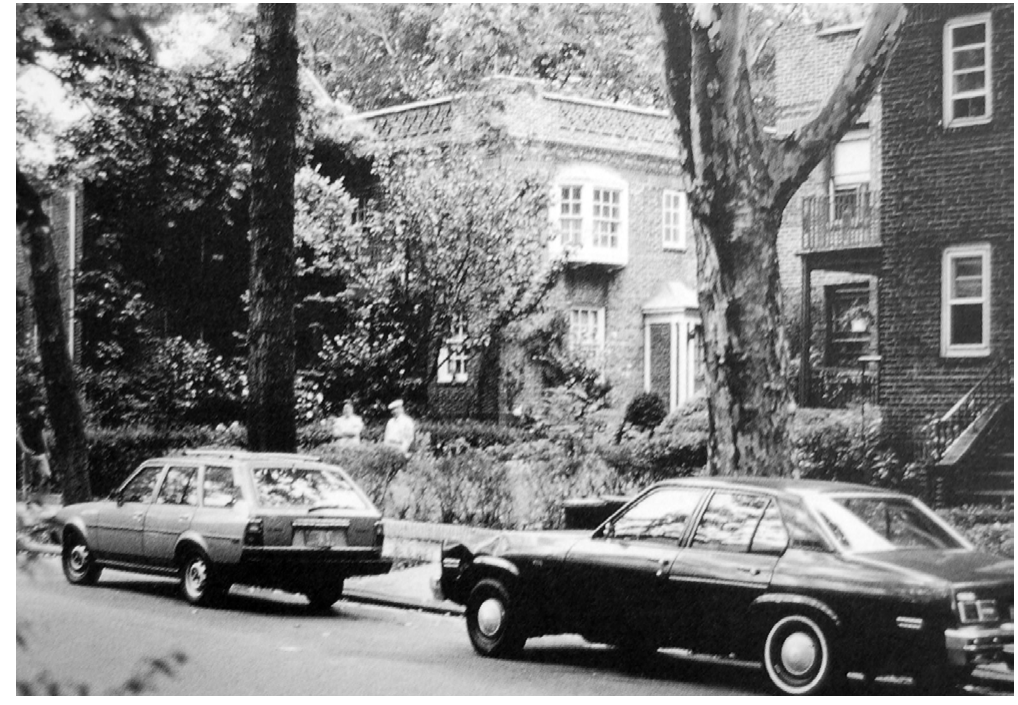

Garden apartment units set back from the street at Sunnyside Gardens
550 square feet for a cooperative garden apartment to 1400 square feet for a one-family attached house. The site layout of housing units was concentrated around the perimeter of the long city blocks, with the garden apartments concentrated around playing fields and playgrounds towards the center of the development. The intention of the design was to give a sense of separate community.

Phase two took shape during the years of 1926 and 1927. During this second phase of development, blocks were subdivided more tightly than in the first phase into smaller quadrangles, well scaled to the surrounding two-story dwellings. This change in approach was due to lessons learnt through the construction of the first phase, where it was said that the courts were simply too noisy and the housing arrangement was impersonal. Three relatively separate garden courts emerged per block in this new arrangement, spanning a width of 120 feet from building to building, of which a depth of 30 feet on each side was devoted to private gardens for adjacent units. Construction of this phase also brought a scaling back of garden apartment construction. Nevertheless, in 1927 apartments were built as revenue-producing ventures for the first time, and not for ownership.

Phase three began during the year of 1927 and continued until 1928. Introduced late in 1926, a U-shaped grouping of dwelling units was developed and constructed during this phase, with 16 units fronting onto a long rectangular entrance court, with the open end of the grouping facing toward the street and gabled at each end. This design served to finish off the development and by turning its back to the outside, insulate Sunnyside Gardens from unwanted visual intrusions.

This large complex is one of New York's most significant planned 


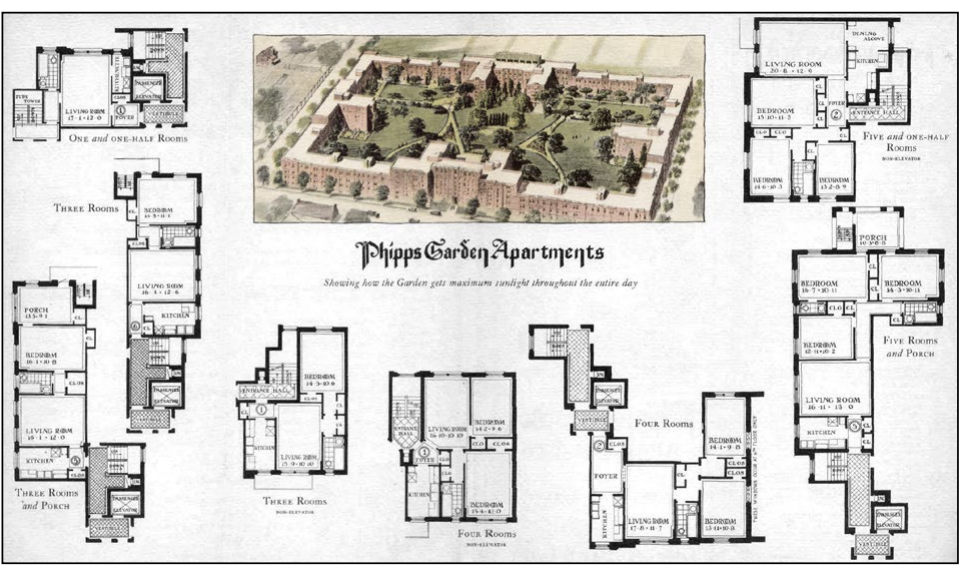

Floor plans showing various sized apartments in Phipps Garden Apartments

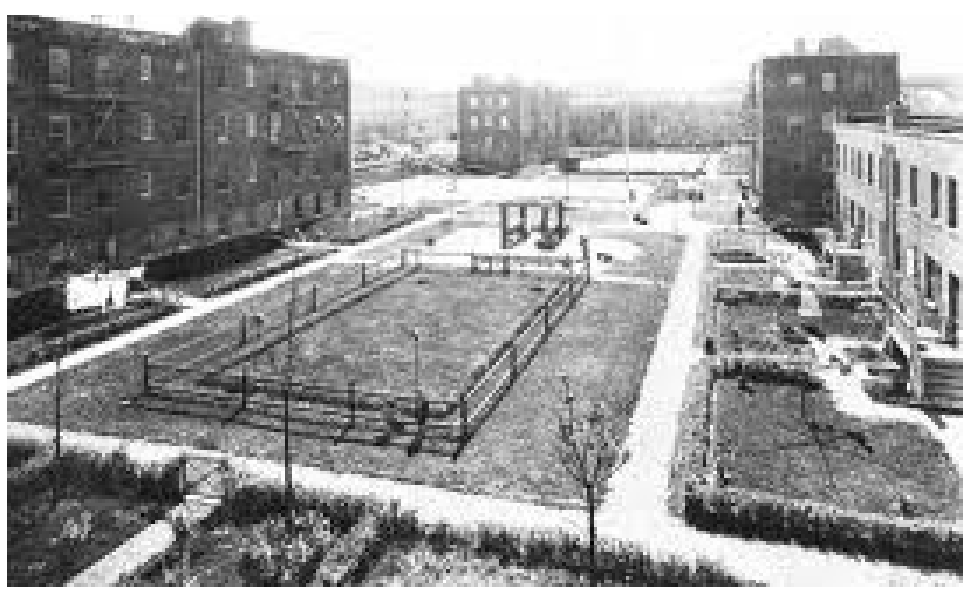

Garden court at Phipps Garden Apartments complex (1937) residential communities and is recognized for its low-rise, low-density housing arranged around landscaped open courtyards. Architectural critic and member of the RPAA, and as well long-time resident Lewis Mumford called the historic site of Sunnyside Gardens "an exceptional community laid out by people who were deeply human and who gave the place a permanent expression of that humanness." ${ }^{17}$

In 1931, on the North of the historic site, Phipps Garden Apartment I was built followed by its companion, Phipps Garden Apartment II, in 1935. Together they encompass an entire double-width block and is the largest apartment complex belonging to Sunnyside Gardens Historic District. The buildings themselves are designed as perimeter block structures, almost completely enclosing an interior garden courtyard. Conceptually, the complex, along with its interior courtyard, was designed to integrate public and private gardens, with the intention that every resident has access to an outdoor space. The design approach to the garden apartment, bringing the idea of the garden courtyard to housing, was an evolution and a significant improvement to the design of the tenement airshaft. ${ }^{18}$

Prior to the 1920s, it was assumed that reduction of building coverage would increase costs and reduce profits, leaving the argument within the realm of social good or marketing of such properties. ${ }^{19}$ The reality, however, was that the low cost of land within the greenbelt surrounding Manhattan facilitated that design of garden homes for a reasonable price, accommodating the flocking of the middle class to the suburbs. The garden apartments of the time reflected a reorganization of capital for the production of middle-class housing to match the scale of the large outer borough parcels. Queens was considered the garden borough, with its more privatized nature, in the form of low density 
housing yards. With the construction of subway lines into Queens and the opening of the Queensboro Bridge in 1909, Midtown Manhattan was only 15 minutes away from open farmland.

\section{ep. 4. POST WWII HIGHRISES:} TOWERS - IN - THE-PARK

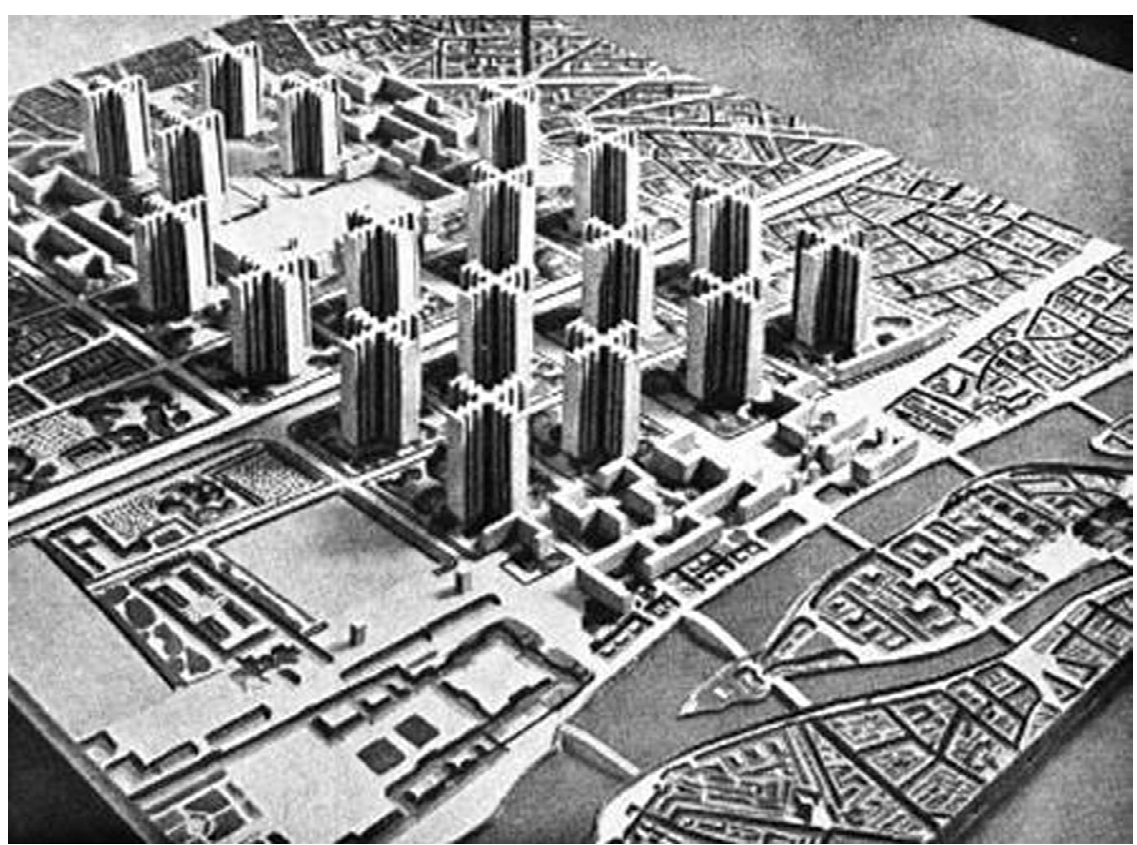

A scale mdel of Le Corbusier's Plan Voisin of 1925. The Seine and Ile-dela-Cité are at the lower right. Concept based off of the ideas implemented by the Randiant City model. From Oeuvre complet de 1910-1929
In post-war housing development, an emphasis was placed on the model of the "tower in the park," a concept based on the diagrams designed by Le Corbusier for his utopian vision for the Radiant City of 1935. Like Ebenezer Howard's Garden City, the Radiant City was a response to the urban pollution and overcrowding of the industrial cities. He believed that the traditional pattern of streetoriented, gridiron urbanism created unhealthy living conditions. Le Corbusier's solution, however, was to build upwards, not outwards. His plan proposed exactly that by dedicating the center of the city to residential program consisting of high-rise apartment blocks, called "Unités." The notion was to pile the city on top of itself to achieve the optimal amount of unhindered ground space for the use of the inhabitants. Enlarging the dimensions of the grid by merging several blocks into one and replacing street walls with freestanding towers on "superblocks would optimize the ground space for pedestrian access. With the apartment blocks raised on pilotis, the population of the city would have the entire surface area of the city at their disposal to expand their whole physical existence. The characteristics of Le Corbusier's ideal city became criteria for the creation of park-like settings for the housing projects of this time. The goal was to rid the 


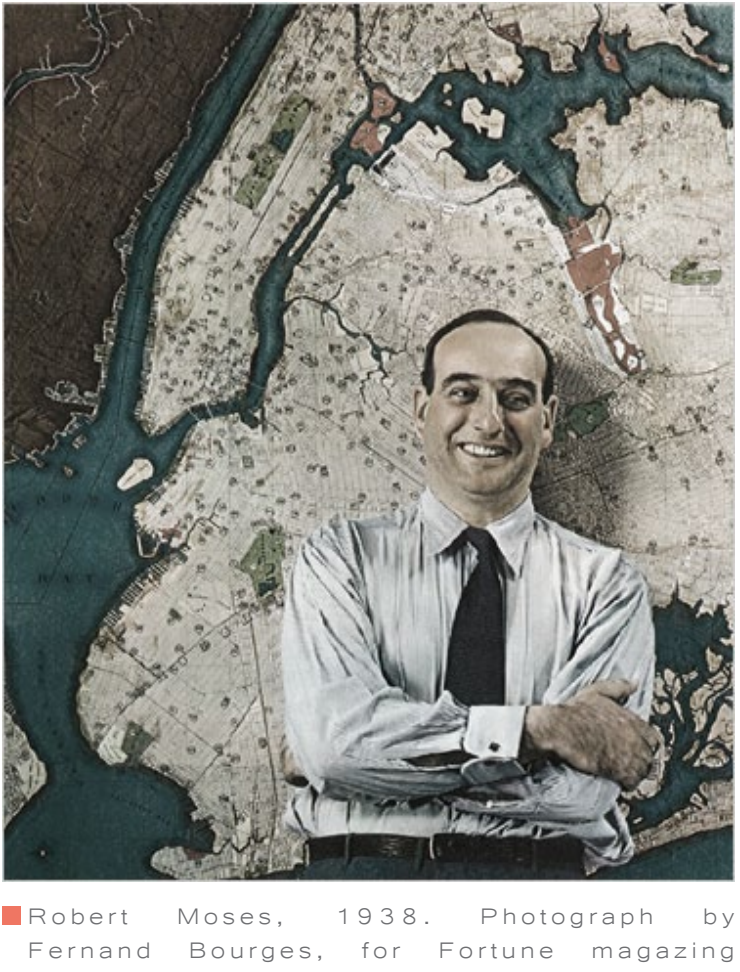

nineteenth century city of its tenements, which had been characterized as slums - dark, cramped, and festering. This was caused by the use of space by the architects of the projects. While nineteenth century tenements covered approximately 90 percent of the land on which they were constructed, these new housing developments proposed slightly more than 10 percent coverage.

As a response to the impacts of the Great Depression, the United States enacted a series of domestic programs collectively called the New Deal. The focus was directed towards the relief for the unemployed and poor, recovery of the economy, and reform of the financial system to prevent a repeat depression. One of the programs developed from the New Deal was the Public Works Administration (PWA), responsible for building large scale projects such as dams, bridges, hospitals, schools, and housing to rejuvenate American cities and their economies. Under the New Deal, Robert Moses, the new commissioner of parks for New York City, orchestrated the largest urban park and playground construction program in the United States. This was the beginning of an extravagant career for Robert Moses as a "master builder" in shaping the modern city of New York through the construction of his roads, bridges, playground, parks and housing projects. In the mid1930s, New Yorkers watched an astonishing transformation unfold as Moses dug deeply into the pockets of the federal government and procured the financial resources needed to equip the city with new facilities for public recreation. ${ }^{20}$ The PWA helped fund Moses's vast system of 3 bridges, 9 parkways, and 255 parks or recreational facilities throughout the New York Metropolitan Region. ${ }^{21}$

The PWA was also the centerpiece of the New Deal program for building public housing for low-income citizens in cities. Beginning in 

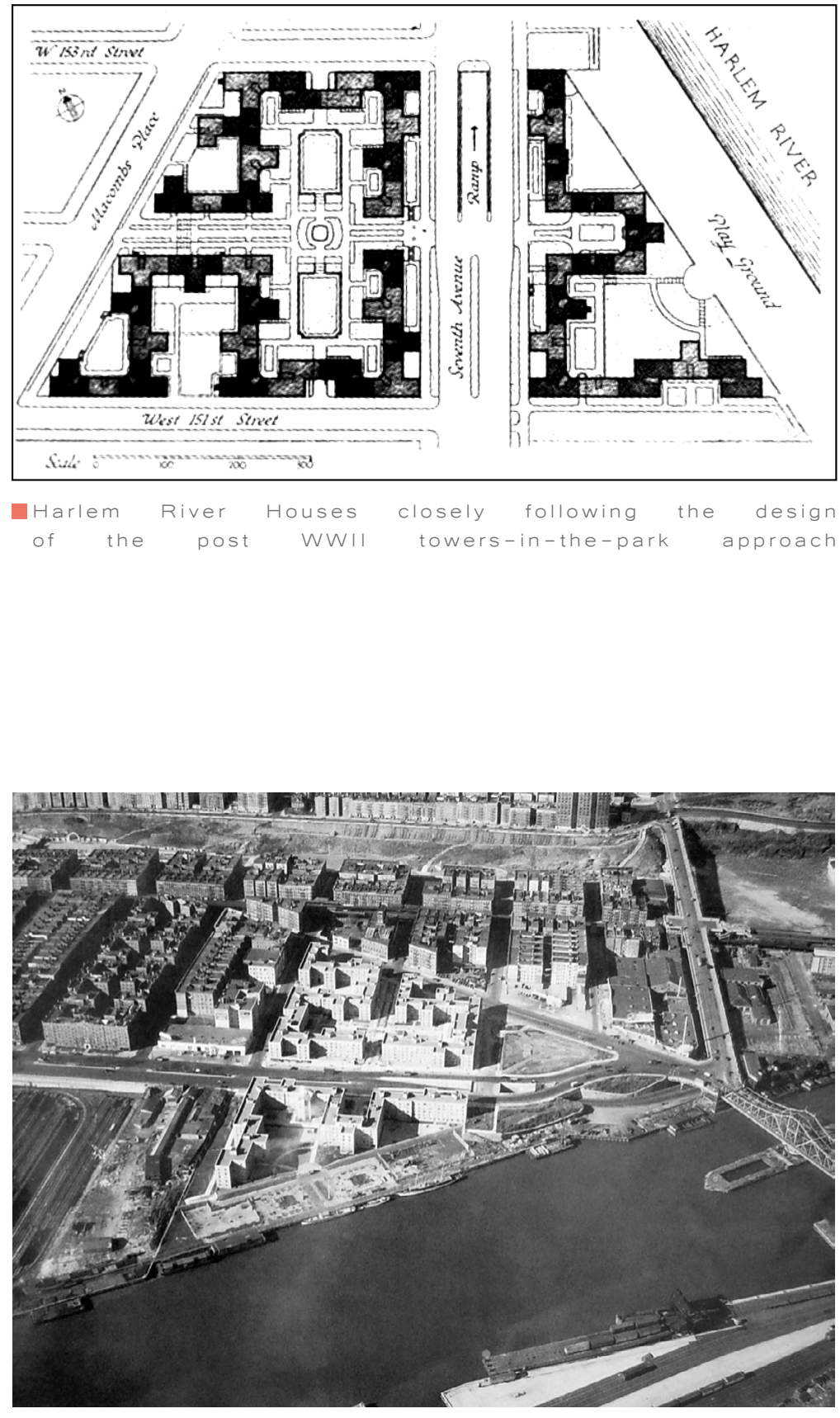

Warlem River Houses, 1937. Photoarchive, courtesy NYCDPR the 1930s, the ideals of the towers-in-the-park saw their expression in a concentration of housing projects along the scenic East River, in Manhattan. ${ }^{22}$ The first housing project of this kind in New York was the Harlem River Houses, built in 1937 under the Public Works Administration. As the name would suggest, it was built along the East River. The choice of this location for the first significant housing project was done purposefully. The architecture was designed to maximize the feeling of spaciousness, and the scenic view of the East River was seen as accomplishing this idealized living condition in the midst of one of the poorest slums in the city. The hope was that, by improving the sense of space, these housing projects would be able to improve the living conditions of the city's poor and thereby reduce crime and other negative conditions associated with the "slums." Robert Moses believed that housing projects should "provide recreation for the surrounding community as well as for the residents of the projects." Supporting this theory, after the opening of the Harlem River Houses in 1937 he expanded the play space by 5.5 acres with two new playgrounds in the area.

Unfortunately, the quality of future projects in Harlem would not be quite as high and would prove to be not as successful in achieving their goals of improving living conditions and quality of life from those of the slums. Although the architectural plans were successfully implemented, they did not achieve the desired effect. Lewis Mumford criticized the concept of the "towers-in-the-park" by arguing that its proponents "confused visual open space with functional (habitable) open space" and that the issue was "not merely the percentage of the land covered by the buildings, but the number of people crowded together in a given area." In retrospect, Mumford appears to have had a point. Studies have shown that such projects display "a tendency to 
increase crime," described by the notion that "the scale of the towers prevent normal exercise of familial territory" and that "removal of large numbers of units from visual contact with open space prevented proper public surveillance." ${ }^{23}$

The housing projects constructed during this time by the PWA, such as the Harlem River Houses, proceeded under the management of the New York City Housing Authority, an organization that provides public housing for low- and moderate-income residents throughout the five boroughs of New York City. The NYCHA was created in 1934 and boomed in partnership with Robert Moses after World War II as a part of Moses's plan to lead the nation's largest slum clearance program in the 1950s. This was made possible by a federal program, Title I of the U.S. Housing Act of 1949 that provided deep federal subsidies for clearance of slum areas in order to stimulate their reconstruction by private developers. As chairman of Mayor Robert Wagner's committee of slum clearance, the entity through which he ran Title I from 1949 to 1960 , Moses announced seven slum clearance projects during his reign. In March 1960, when Moses was forced to resign as chairman, his approach too urban renewal was publicly rejected. Mayor Robert Wagner disbanded the committee and installed a new system designed to correct Moses's errant ways: his secretive selection of sites and sponsors, privatization of relocation, and opposition to preservation. ${ }^{24}$ Moses trusted the wisdom of professional expertise over the local concerns of residents, and he put the interests of the city over those of the neighborhood.

Moses had a strategic vision. His aim was to strengthen the center city in an age of decentralization, suburban drift, and urban decay. Towards this end, he pursued a three-part strategy: build housing for 


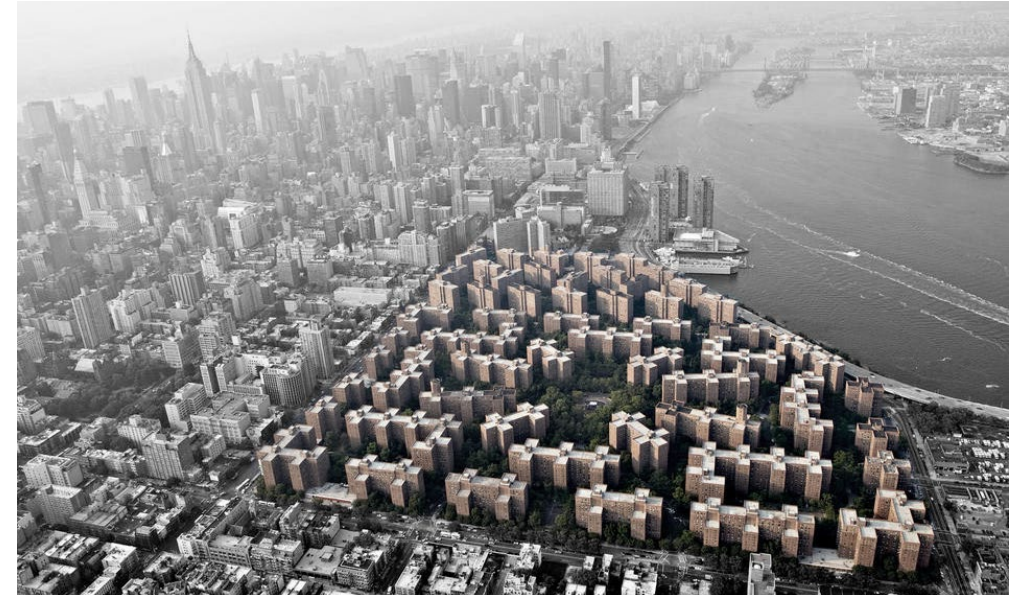

Stuyvesant Town (foreground) and Peter Cooper Village.. Photo by Thomas Airviews, Collection MTA Bridges and Tunnels Special Archive.

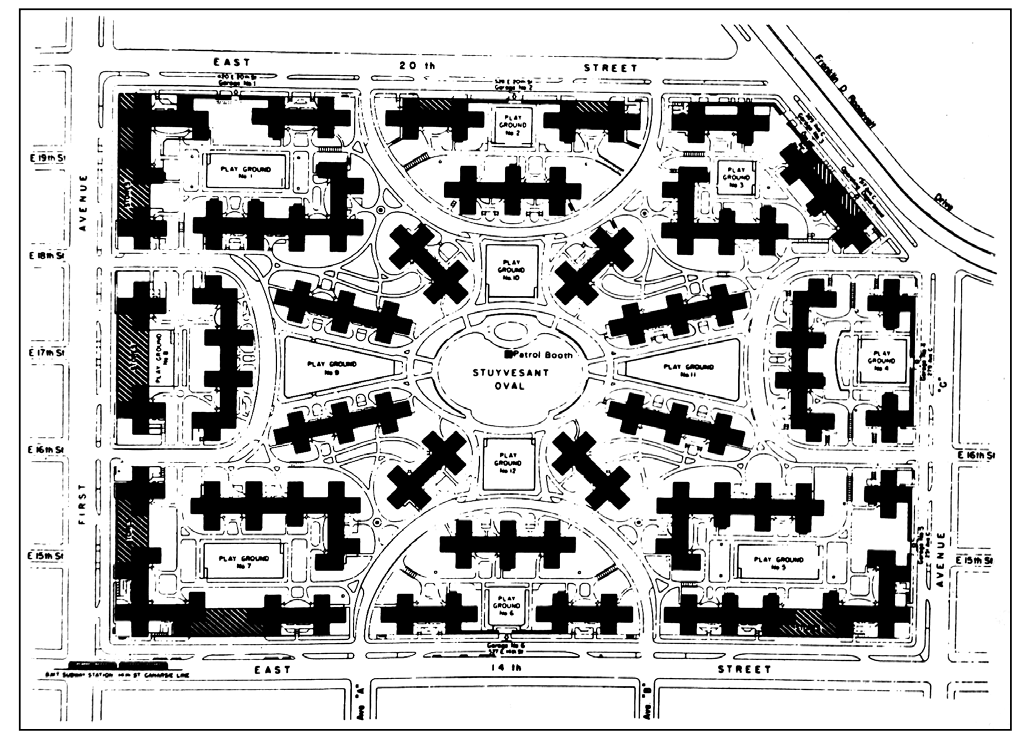

A "city in the park" development. The panopticon-like site organization included a patrol booth for police at the center for the security of the residents middle class, expand higher education, and promote the city's cultural prominence. Admittedly, this redevelopment agenda did not benefit all alike. The losers were those displaced from the tenement districts: the poor, Puerto Ricans and African Americans, and small-business owners, often banished to other slums. The beneficiaries were middle and upper-class residents; universities, college students, an economy propelled by brainpower; and cultural institutions, suburbanites, and tourists who saw New York as a cultural magnet. ${ }^{25}$ Moses's approach to Title I was informed by his efforts in the 1940s to involve private capital in slum clearance. He stated at the beginning of each slum clearance plan that the field of urban renewal was "new, untried and experimental" and that the progress is therefore likely to be "slow and cumbersome."

In 1942, Moses assisted the Metropolitan Life Insurance Company in assembling the sites for several slum clearance-redevelopment projects in Manhattan. Two of the projects were Stuyvesant Town and Peter Cooper Village, planned beginning in 1942 and opened their first building in 1947. Both developments are adjacently located on the Lower East Side, between Avenue C, First Avenue, East $14^{\text {th }}$ and East $23^{\text {th }}$ Streets. Stuyvesant Town, located between $14^{\text {th }}$ and $20^{\text {th }}$ Streets, has 8,757 apartments in 35 residential buildings. The complex has a combined 56 residential buildings, 11,250 apartments, and over 25,000 residents. The clearance of the area was made with the considerable assistance of Robert Moses, who demonstrated for the first time his capacity to implement what came to be called the "bulldozer approach" to urban renewal. He saw slums as a spreading cancer, and clearance and superblock urbanism as the only effective cure. ${ }^{26}$ The controversies associated with his techniques on relocating existing residents, however, were concerning. For Stuyvesant Town 

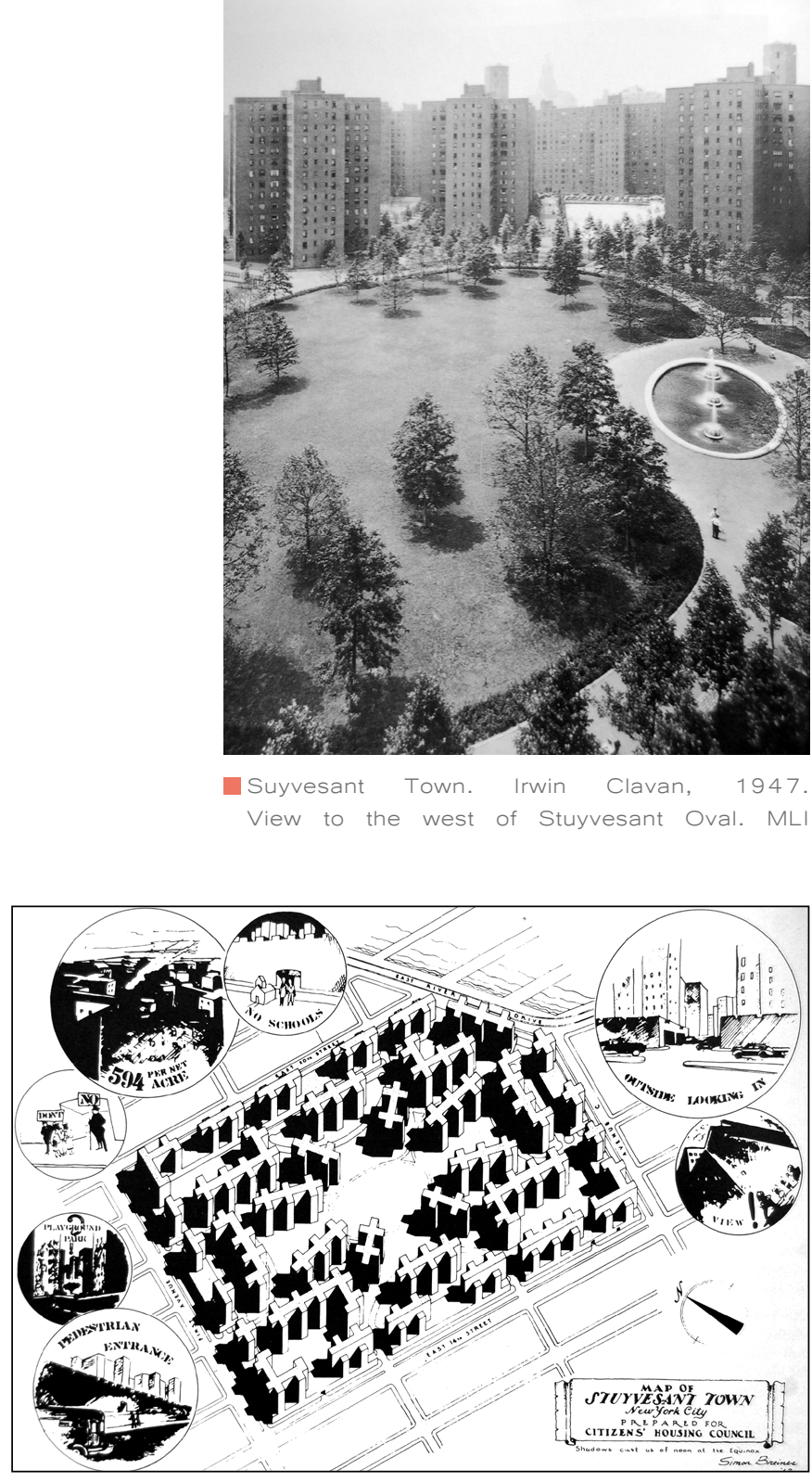

Gimon Breines. Analysis of Stuyvesant Town prepared for the Citizen's Housing Council in 1943, identifying some of the "dubious features" of the design alone, Moses relocated over 12,000 people, promising them help with placement into adequate housing elsewhere in the city with a "minimum of inconvenience." ${ }^{27}$ A substantial number of families did not receive the promised aid in relocation to low-income public housing projects and ended up in other slums with dismal conditions.

The tower floor plans combined several core types into single large blocks, and the site was designed for maximum security against unwanted external intrusions. A combination of brick walls and low commercial and parking structures surrounded the perimeter of the developments, making pedestrian and vehicular access to the site extremely limited. The Manhattan gridiron was completely dissolved within the complex and the internal spaces heavily landscaped. The "tower in the park" mode was advantageous in terms of control, from the "inside out" as well as the "outside in." A contrast between Stuyvesant Town-Peter Cooper Village and the public housing tower projects was the interpretation of the "park." In the middle-class Stuyvesant Town-Peter Cooper Village, the park reinforced the role of the tower as a secure residential fortress, in tradition of the fortress towers for New York's affluent since the 1880s. For public housing the park also reinforced the fortress aspect of the tower, but it also symbolized the antithesis of security, which was containment rather than protection of the tenants. ${ }^{28}$ The "tower in the park" symbolized a new era of racial and economic inequality, isolating the differences instead of the similarities in society. In 1943, the parks commissioner, Robert Moses, engineered an amendment to the 1942 Redevelopment Companies Act specifically to ensure that Met Life would be free to bar African Americans from the complex. ${ }^{29}$ Met Life defended its right to racially discriminate on tenant occupancy and therefore, 
Stuyvesant Town-Peter Cooper Village was furtively planned as an allwhite, middle-class complex, fortifying the segregation of ethnicities throughout the city.

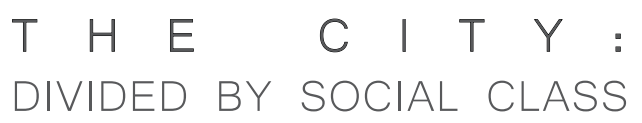

New York became a modern city in the first decades of the nineteenth century. Between 1820 and 1860, New York City became a city not of "houses" but of "housing." ${ }^{30}$ With the population growing rapidly, the rise in physical congestion was altering the cultural formwork of the city. The conditions intermingled social classes from the tenements of the poor to the progressively dense row houses of the upper middle class. The cellars were possibly the worst housing option for the poor because of the lack of ventilation, and natural light. They frequently filled with gases from primitive sewer systems; and because of their wet, dark, airless nature, they were a breeding ground for cholera, malaria, and tuberculosis. The "rookery housing" was a term that predated the tenement and were usually discarded building haphazardly re-inhabited at tenement densities. Many were formerly single-family houses built of wood frame construction before inexpensive brick was available.

Despite their aspirations to remain amongst the density of the inner city, the upper-middle class and the upper class clung to the ideal of the individual house on a lot of land. For Manhattan during this era, 


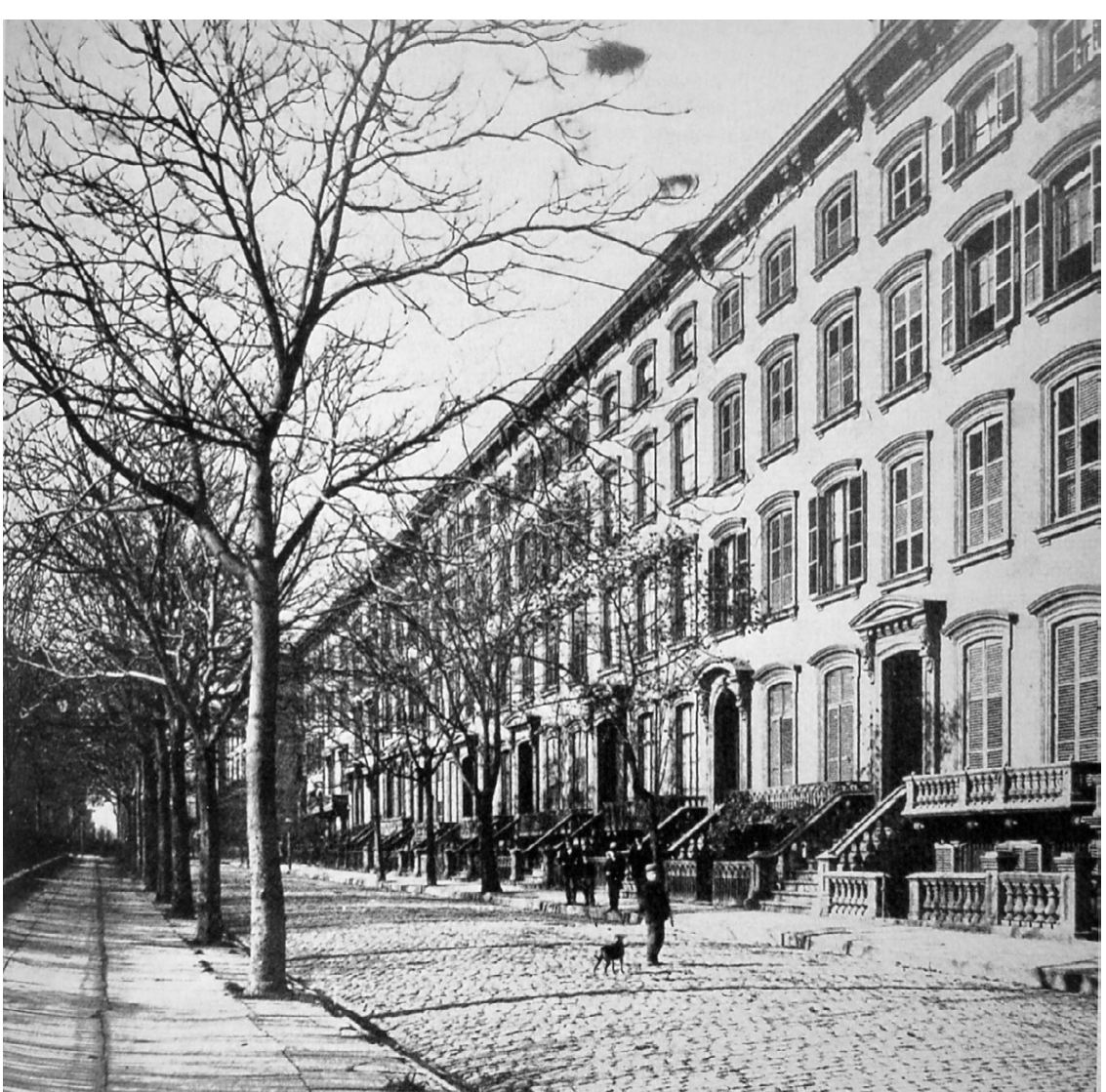

VIew from Madison Avenue along East Twenty-sixth Street, c. 1868 showing brownstonerow facing Madison Square Park. Anthony. FLC. the notion was not economically viable and it also held many physical constraints. With the density of the city only growing stronger, accommodating more people on a single lot was necessary to house the population. In the 1880s, the affluent population refused to live in apartments designed similar to the "French Flats". It was not a popular idea for those who could afford to live in Row houses, similar to the bourgeoning middle-class in Paris in the time of Haussmann. ${ }^{31}$ They recognized that the nineteenth-century apartment house was a new building type that was being made even more new during the Second Empire. But rather than embrace the novelty and technological advances of modernity in the apartment house, they articulated a cultural ideal that rejected the new form of the apartment building in favor of a distinctly pre-modern and rural ideal: the single-family house, occupied by many generations of one patrilineal family. This notion stemmed from the "Anglo-Saxon" bias towards the "house" and ownership. Therefore, the design of the brownstone was a compromise to house the affluent population of the city. It was an evolution of the row house in Manhattan and was placed on a 25 foot by 100 foot lot within the gridiron of the city. The apartments designed for the affluent were adopted by the burgeoning middle class who wanted to remain in the density of the populated neighborhoods but could not afford brownstones. Social status seemed to be a critical issue of this era as it remains today. Americans saw their houses as a label of their social status.

The second half of the nineteenth century in New York City saw technological innovations in the production of housing which had been unimagined two decades earlier. The steel skeleton frame, the elevator, electricity, and modern sanitation had created the high-rise New York 
apartment house. With this development came the greatest gap of social equality of classes between the rich and the poor that New York has ever experienced. The upper class welcomed the development of the new technology and what it had created, while the lower class remained in their cellars, rookeries, and squatter shacks because they simply could not afford to leave. In 1895, the Board of Health approved a movement of slum clearance and in less than one year, eighty-seven buildings were condemned in the Upper West Side or Dutchtown. Shanty towns were decimated and tenements and upperclass housing replaced them. For the first time, apartments eclipsed the prestige of the brownstone. There was a certain status associated with being above the dirt and the noise of the city streets, which was made possible by the elevator:

with this new era of "sky homes" and "huge compact structures with their hives of families" would evolve a new form of urban intercourse created by unprecedented density organized according to a "method of scientific compactness." In the "pure empyrean above" would be roof gardens which would contrast some of the best features of suburban life with the metropolis below, creating a particular admixture of built for and nature unknown in previous epochs. ${ }^{32}$

For much of this new high density housing, there was a fine line between the tenement and the apartment, especially for the modest income. By this time the middle class was being forced out of the highest density areas of Manhattan because of the lack of adequate 


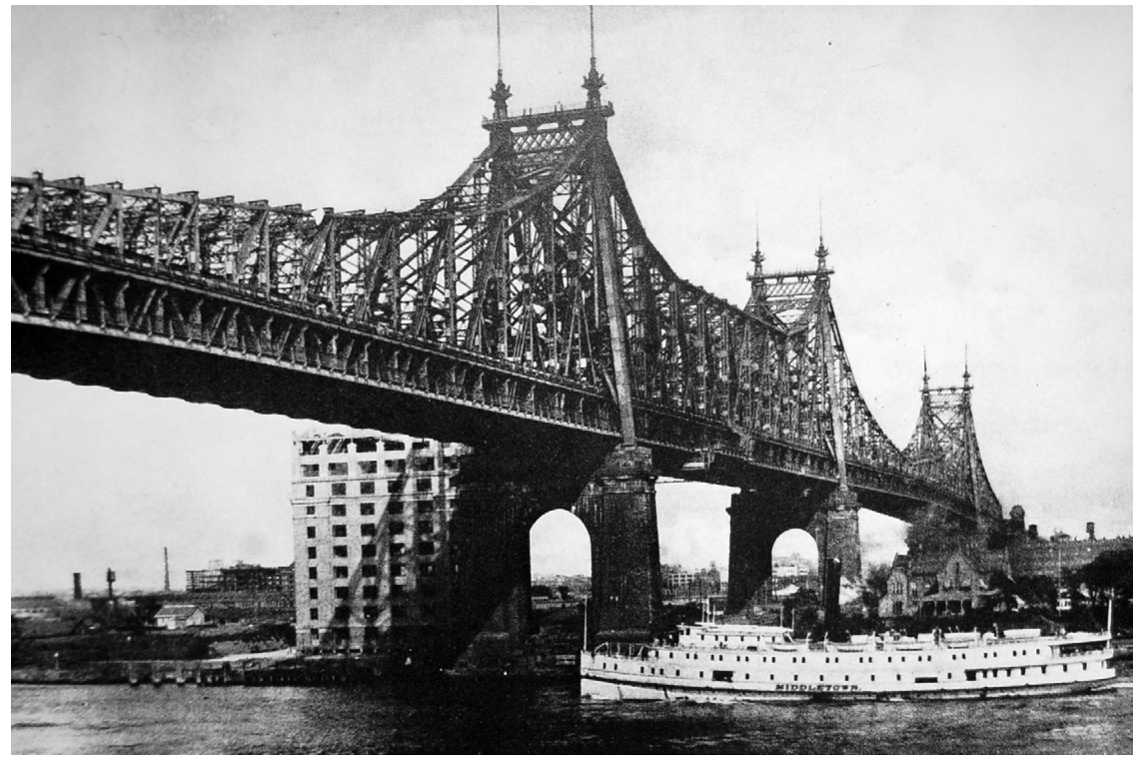

Queensboro Bridge. Henry Hornbostel and Gustav Lindenthal, 1909. MCNY moderate-cost housing, a condition which has since proved to be chronic for the city. The rich and the poor were increasing with most of Manhattans population living in tenements while the remainder occupied the extravagant brownstones, and the great middle class was being crowded into the suburbs. Improvements in mass transportation encouraged the middle class to move to the periphery, in Harlem or Brooklyn, where single-family ownership of a modest row house was still possible. Major urbanization began in the Bronx because of its North/South connection to Manhattan, and Brooklyn then Queens came next.

In 1909 the construction of the Queensboro Bridge was completed which promoted the Queensboro Corporation to advertise cooperative apartment ownership for moderate incomes, instead of luxury housing as in the past. This developed the areas of Corona, Jackson Heights, and Douglaston with housing for the middle-class. Queens was considered the "Garden Borough" but its nature was more privatized, in the form of low density housing yards, belonging to the "garden apartments," like those of Sunnyside Gardens, rather than public parks like those of the Bronx. 
1. Florian Urban. Tower and Slab: Histories of Global Mass Housing (Abingdon, Oxon. England: Routledge, 2012), 2.

2. Louis Winnick. New People in Old Neighborhoods: The Role of New Immigrants in Rejuvenating New York's Communities. (New York: Russell Sage Foundation, 1990), 34. 3. Gwendolyn Wright. Building the Dream: A Social History of Housing in America (New York: Pantheon, 1981) 117.

4. Robin Evans. "Rookeries and Model Dwellings: English Housing Reform and the Moralities of Private Space, in Translations From Drawings to Buildings" Architectural Association Quarterly 10.1 (1978), 98.

5. Jared N. Day. Urban Castles: Tenement Housing and Landlord Activism in New York City 1890-1943 (New York: Columbia UP, 1999), 21.

6. Charles E. Rosenburg. The Cholera Years. The United States in 1832, 1849, and 1866, (Chicago: University of Chicago Press, 1962), 190

7. Jared N. Day. Urban Castles: Tenement Housing and Landlord Activism in New York City 1890-1943 (New York: Columbia UP, 1999), 16.

8. Robert A. Stern. M., Gregory Gilmartin, and John Montague. Massengale. New York 1900: Metropolitan Architecture and Urbanism, 1890-1915. (New York: Rizzoli, 1983), 496.

9. Jared N. Day. Urban Castles: Tenement Housing and Landlord Activism in New York City 1890-1943 (New York: Columbia UP, 1999), 26.

10. Gwendolyn Wright. Building the Dream: A Social History of Housing in America (New York: Pantheon, 1981), 140

11. Peter Rowe. Modernity and Housing (Cambridge, MA: MIT Press, 1993), 50.

12. Paul R. Baker. Richard Morris Hunt. (Cambridge, MA: MIT 1980), 104.

13. C.O Loring. Stuyvesant Apartments (American Builder 2, 1869), 233.

14. Peter Rowe. Modernity and Housing (Cambridge, MA: MIT Press, 1993), 124

15. Robert Fishman. Urban Utopias in the Twentieth Century: Ebenezer Howard, Frank Lloyd Wright, and Le Corbusier. (New York: Basic, 1977), 41.

16. Virginia Kurshan. Sunnyside Garden Historic District. Rep. no. 3600. New York: New York City Landmarks Preservation Commission, 2007. 7.

17. Virginia Kurshan. Sunnyside Garden Historic District. Rep. no. 3600. New York: New York City Landmarks Preservation Commission, 2007. 9.

18. Robert A. M. Stern, Thomas Mellins, and David Fishman. New York 1960: Architecture and Urbanism between the Second World War and the Bicentennial. (New York, NY: Monacelli, 1995), 515.

19. Richard Plunz. A History of Housing in New York City: Dwelling Type and Social Change in the American Metropolis (New York: Columbia UP, 1990), 135. 
20. Hilary Ballon and Kenneth T. Jackson. Robert Moses and the Modern City: The Transformation of New York. (New York: W.W. Norton \&, 2007), 72.

21. Gwendolyn Wright. USA: Modern Architecture in History. London: Reaktion, 2008.

22. Richard Plunz. A History of Housing in New York City: Dwelling Type and Social Change in the American Metropolis (New York: Columbia UP, 1990), 210.

23. Lewis Mumford, The Sky Line, "STUYVESANT TOWN REVISITED," The New Yorker, November 27, 1948. 65.

24. Hilary Ballon and Kenneth T. Jackson. Robert Moses and the Modern City: The Transformation of New York. (New York: W.W. Norton \&, 2007), 94.

25. Robert A Caro. The Power Broker: Robert Moses and the Fall of New York (New York: Vintage, 1975), 718

26. Hilary Ballon and Kenneth T. Jackson. Robert Moses and the Modern City: The Transformation of New York. (New York: W.W. Norton \&, 2007), 113.

27. Robert A Caro. The Power Broker: Robert Moses and the Fall of New York (New York: Vintage, 1975), 969.

28. Richard Plunz. A History of Housing in New York City: Dwelling Type and Social Change in the American Metropolis (New York: Columbia UP, 1990), 256.

29. Hilary Ballon and Kenneth T. Jackson. Robert Moses and the Modern City: The Transformation of New York. (New York: W.W. Norton \&, 2007), 117.

30. Richard Plunz. A History of Housing in New York City: Dwelling Type and Social Change in the American Metropolis (New York: Columbia UP, 1990), 4.

31. Sharon Marcus. "Haussmanization as Anti-modernity: The Apartment House in Parisian Urban Discourse, 1850-1880." (Journal of Urban History 27.6 2001), 730.

32. Richard Plunz. A History of Housing in New York City: Dwelling Type and Social Change in the American Metropolis (New York: Columbia UP, 1990), 68. 


\section{chapter two}

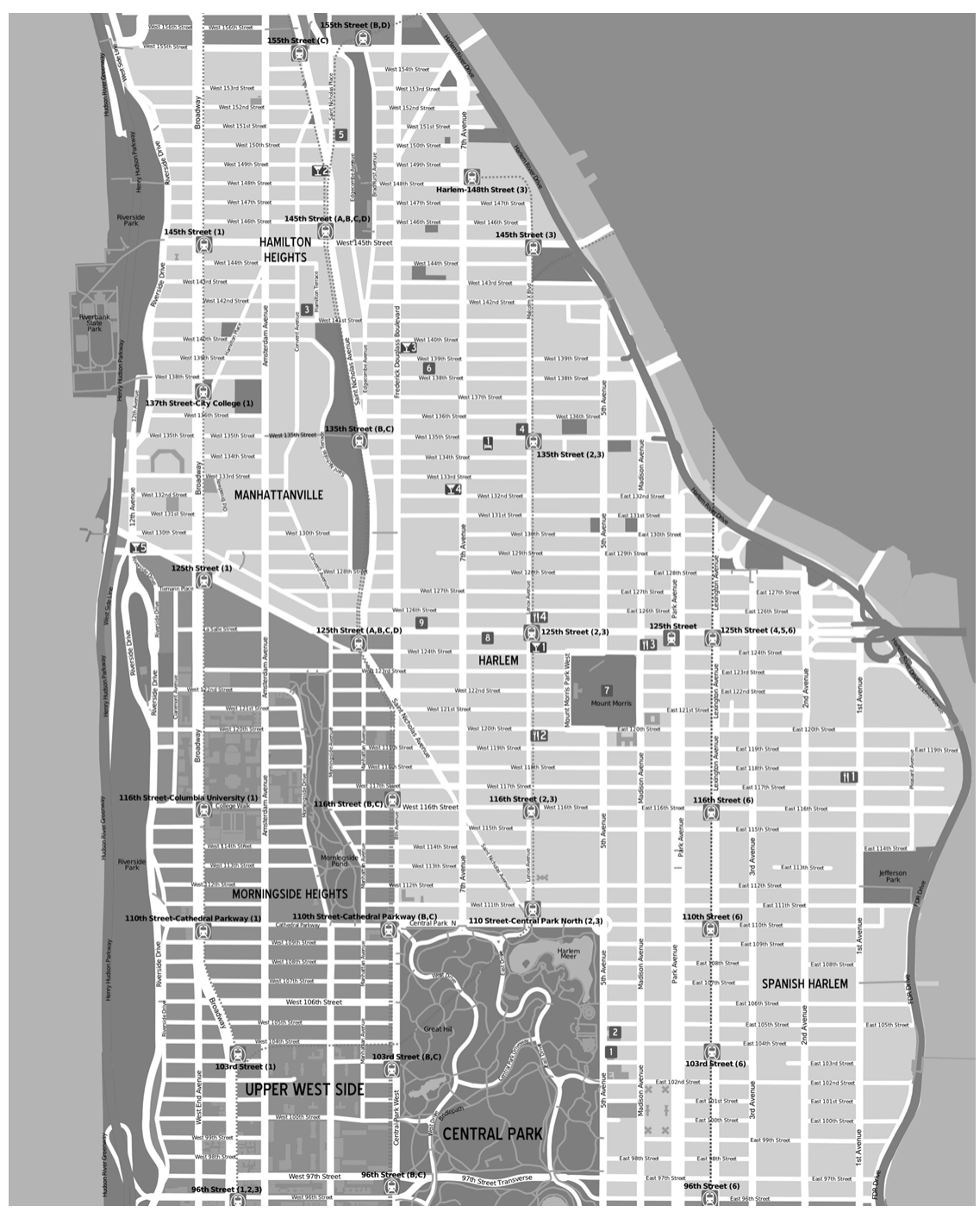

Map of Harlem, New York. NYC \& Company Inc. 2005

\section{GENTRIFING NEGHBRHOODS:}

\author{
HARLEM, NEW YORK
}

Harlem is a large neighborhood in the northern section of Manhattan. It may generally be said to lie between 155th Street on the north, the East River and Harlem River on the east, 96th Street (east of Central Park) and 110th Street and Cathedral Parkway (north and west of Central Park) on the south, and Amsterdam Avenue on the west. Like the rest of the city, Harlem has experienced its share of demographic change and economic gentrification and continues to be site in a state of social flux.

In the early nineteenth century Harlem remained a quiet neatly laid out community of country estates and farmland. By the mid-1840s the soil was exhausted and Irish squatters occupied the land. ${ }^{33}$ In 1873, some of Harlem's marshlands were drained for the construction of new housing as an attempt to revitalize the area. Also around the same time the anticipation of elevated railroads, which were to be extended into Harlem, supported this plan for improvement, and the once abandoned land began to take on the aspects of a well-planned and well-groomed town. In 1876, row houses began to be constructed in large numbers, but with the growing population even this form of housing would not suffice. Eventually large-scale apartment buildings became the norm. According to writer James Weldon Johnson,

Harlem was not a fringe area, nor a slum or a "quarter consisting of dilapidated tenements." Instead it was a section of new-law apartment houses and handsome dwellings, with streets as well paved, as well lighted, and as well-kept as in any other part of the city. 
Three main highways lead into and out from upper Manhattan, and two of them run straight through Harlem. So Harlem is not a section that one "goes out to," but a section that one goes through. ${ }^{34}$

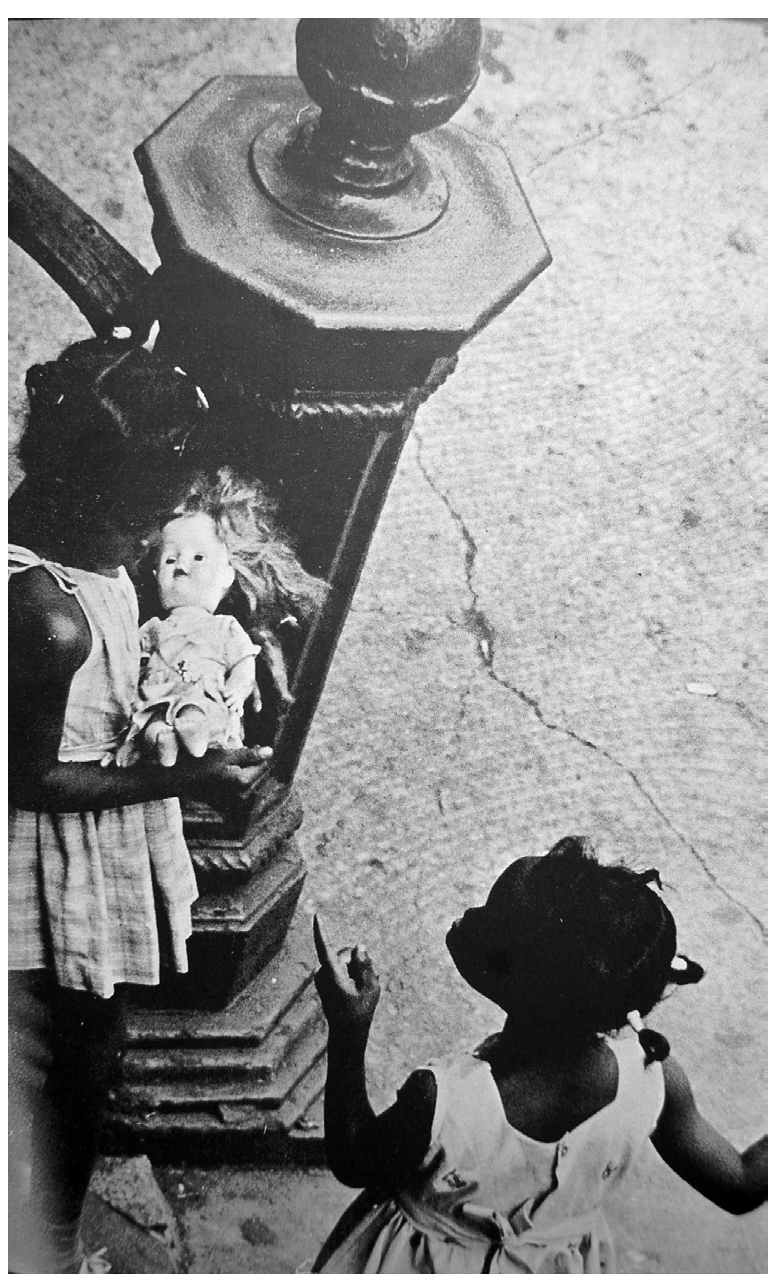

Pictures from Harlem: The work, The children, The play, The issues, The joy and sadness, and watchful waiting. Photograph by John Taylor
The change in Harlem's complexion was swift. Harlem at the turn of the century was demographically a predominantly white enclave with a mixture of ethnic character that was part German, Part Irish, and part Eastern European. The Jewish mafia settled into East Harlem and soon expanded their operations throughout the entire neighborhood. The Jewish presence in Harlem was short-lived, and by 1930, only 5,000 remained. The Puerto Rican population began to emerge in 1913 and quickly took over the apartments of the departing Jews. The Italians in Harlem lasted longer, and traces of the community could be found in the area up until the 1970s.

In the early twentieth century, large immigration of African Americans to northern industrial cities was fueled by their desire to leave the South, seek better jobs and education for their children, and escape a culture of discrimination and segregation. Waves of southern African Americans from the Carolinas, Georgia, and Virginia streamed into the area. The African American community occupied an area called "Negro Harlem," which developed into the largest black community in the country. It was really a "city within a city" covering in its three and a half square miles close to four hundred city blocks. ${ }^{35}$ By 1920, the population of Central Harlem was 32 percent African American, and by 1930 the percentage of African American population went as high as 70 percent living in Central Harlem, as far as Central Park at $110^{\text {th }}$ Street. 


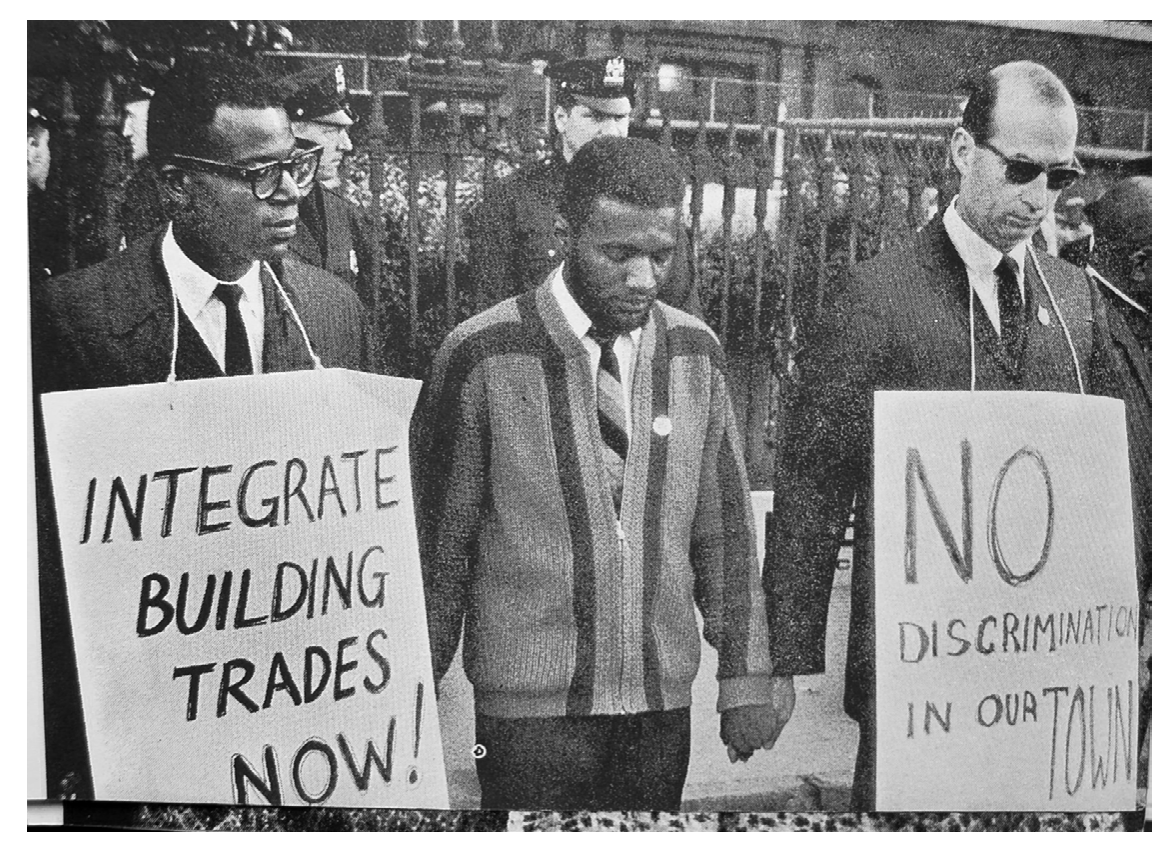

Dictures from Harlem: The work, The children, The play, The issues, The joy and sadness, and watchful waiting. Photograph by John Taylor
The move into Harlem by the African American community coincided with another massive wave of European immigrants coming into the city, this time from the Mediterranean region, mostly being Italians, Sicilians, and Greeks. This was difficult for the African American community because the jobs they were fighting for became a competition between them and the newly emigrated Mediterranean population. The city's Mayor, Fiorello La Guardia, spoke of the area as a place where "as nowhere else in the world ... the people of all races, religions, creeds, and color can live as neighbors." But that was an exaggeration. By the time La Guardia made that remark, in the mid-1940s, each ethnic group had carved out its own territory and did not stray into its neighbor's. At this point, the new-law tenements and handsome dwellings of Harlem had begun to deteriorate into the nation's largest slum. ${ }^{36}$ The unhealthy conditions were spawned by congestion and the negligence of landlords in providing services and repairs. At first it seemed as though the communities of whites and African Americans could live together, but that was the grand illusion. Instead what was happening resembled that of a revolving door, as the African American community was quickly growing, the white community of Harlem just as quickly decided to leave. Not without racial controversy did this change in demographic occur, but between 1920 and 1930, over 100,000 white residents moved from Harlem, mainly because of the arrival of the African American community. ${ }^{37}$

In the 1920s was also The Harlem Renaissance, when writers and poets such as Mckay, Johnson, Countee Cullen, and Langston Hughes gave African Americans throughout the United States a sense of their own history and tradition, and voiced their yearnings. It was a period when, as Hughes put it, "the Negro was in vogue." ${ }^{38}$ The traditions of the Harlem Renaissance were often driven by poverty, crime, and 


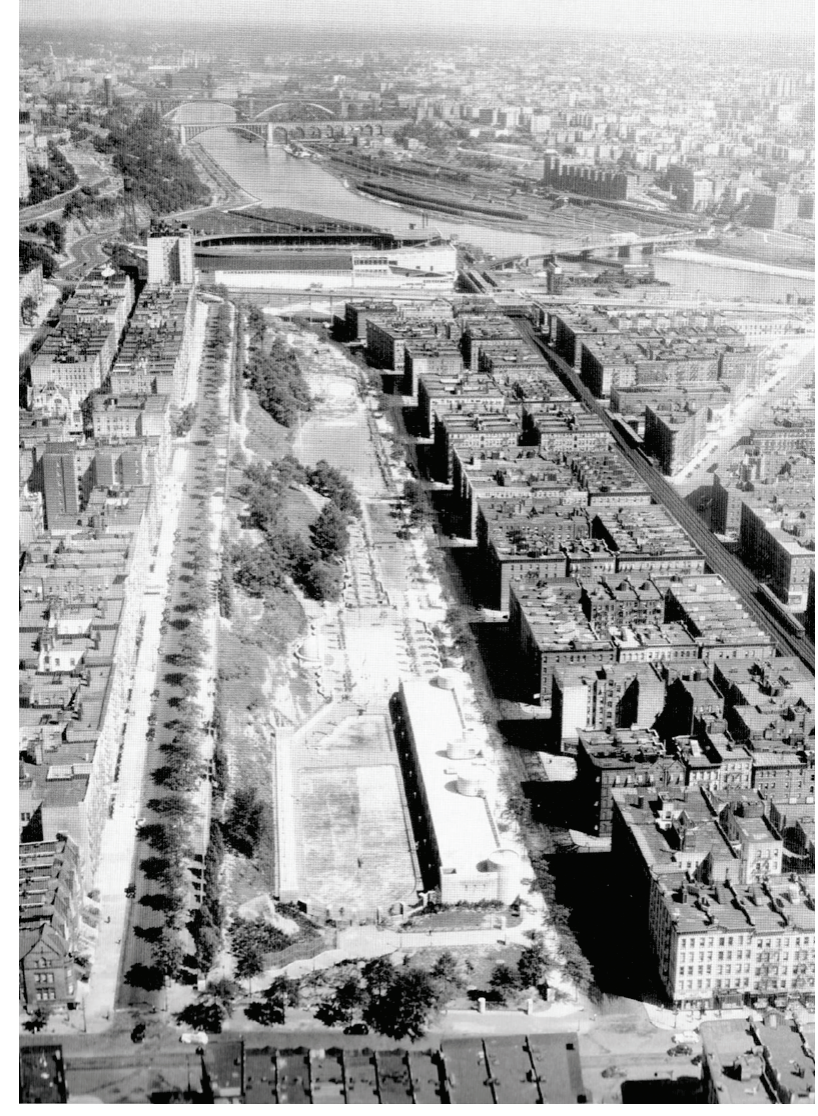

Colonial Park, with pool and recreation areas, September 8 1937. New York University Archives, Photographic Collection. other social ills. During this era, over one quarter of African American households in Harlem made their monthly rent by hosting rent parties to raise money and taking in lodgers, who sometimes brought in bad social habits and even crime which disrupted the lives of respectable families. The high rental costs and the deteriorating housing stock cannot be blamed on racism by white landlords, as a significant amount of the neighborhood was owned by wealthier African American residents.

The 1920s were also the Jazz Age, and jazz reigned supreme in Harlem. Harlem was a working person's community, but at night it was a playground for white people. White men and women cabbed up to see the lavish shows at nightclubs such as the Cotton Club, where African Americans were barred and the only ones seen on the premises were either in the chorus line or the band. In 1930 when the depression started, the Renaissance had run its course. Langston Hughes said, "All of us knew that the gay and sparkling life... was not so gay and sparkling beneath the surface." ${ }^{39}$

Harlemites enjoyed benefits from the massive public works projects under Robert Moses in the 1930s, with his attempts to accommodate the need for recreational facilities within the urban fabric of the city. He focussed his efforts on including the needs of this community in the pool building campaign of the time, for example his decision to expand Colonial Park along a rock outcrop in western Harlem turned an underused piece of land into a much-needed civic amenity. The need for this kind of investment was made clear the previous year when race riots exploded in Harlem and the lack of recreational facilities was stated as a contributing cause. ${ }^{40}$ The park improvements including the construction of a grand new swimming pool, mall, music 


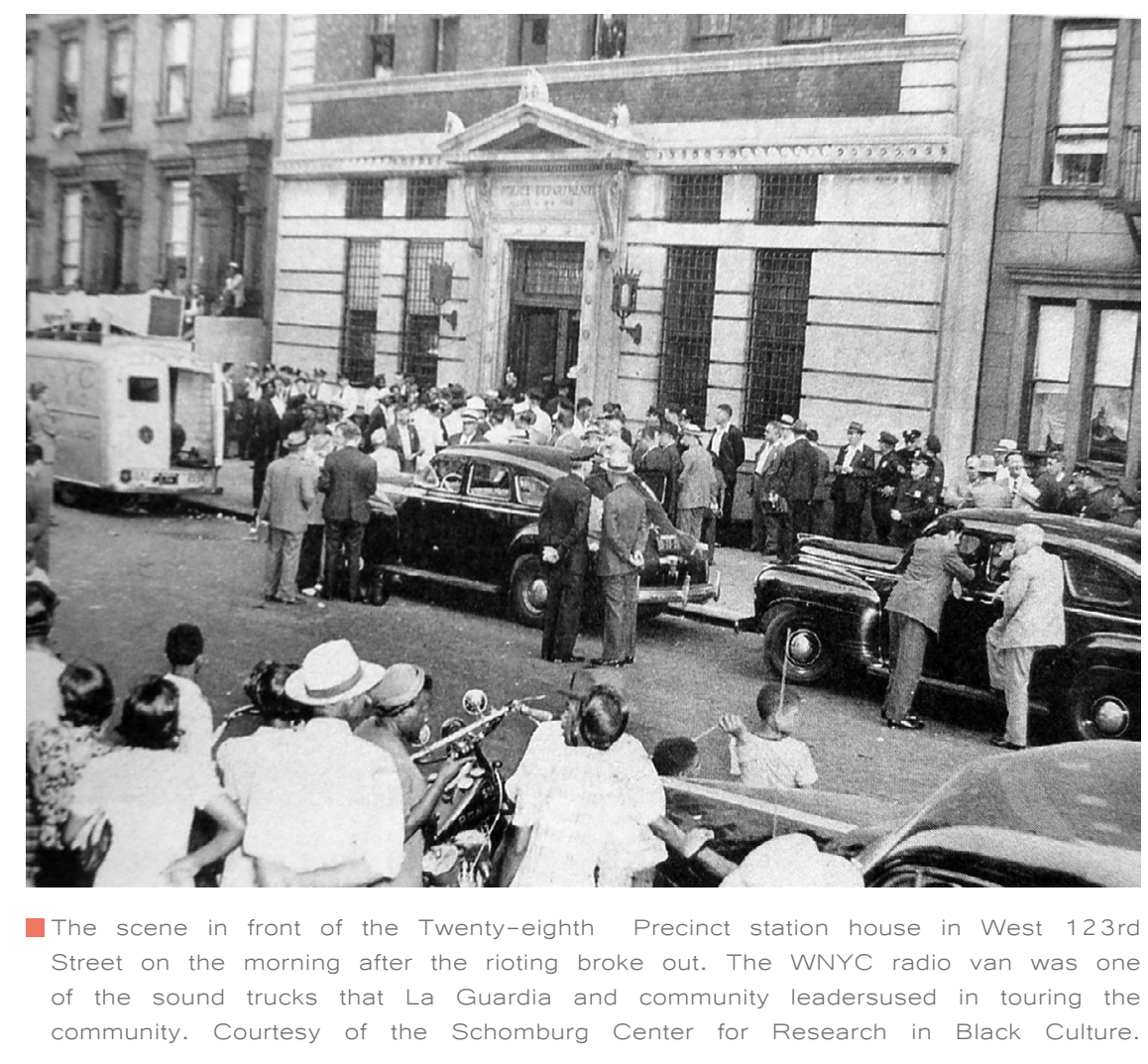

pavilion, playgrounds, and Embury's fortress like brick bath house. The pool opened before construction was even finished because of urgent social need, as well as to counter charges of racial bias in the city's public works program. At the opening of the complex, Moses reported that the pool had been built by the people of Harlem and would be operated by them, and he urged the crowd to take care of the pool. The expansion of Colonial Park was one of many new open-air facilities for swimming and bathing that dotted the landscape of the entire city, albeit to a greater degree in Manhattan than in the outer boroughs and to a lesser degree in African American neighborhoods than in white ones.

In the 1950s and early 1960s, Harlem witnessed a series of rent strikes by neighborhood tenants fighting for the city to force landlords to bring the quality of housing up to code, to rectify the issue of rodent infestation and lack of heat during the winter months, and to respect the regulations of the rent control laws. Little investment in private homes took place in the neighborhood between 1910 and the 1990s; and due to the unwillingness of landlords elsewhere in the city to rent to African American tenants, for many years the rents in Harlem were higher than anywhere else in the city, even as the housing stock deteriorated. Many groups mobilized in Harlem, fighting for better schools, jobs, and housing. One can say the result of these movements brought forth the largest public works developments in Harlem, at the time, regarding housing. The concentration of the development was built in East Harlem, where existing structures were torn down and replaced by city-designed and managed properties. Mostly, these housing projects took the form of the tower-in-the-park, high-rise apartment complex model. Most of these public housing complexes are managed by the New York City Housing Authority. The goal was to 
provide a more pleasant living environment as well as moving away from the issues faced with private landlords.

In the post-World War II era, Harlem ceased to be home to most of the African American community in New York City, as the character of the community changed with the middle-class leaving to live in the outer borough suburbs. Thereafter, Hispanic and Asian communities have in filled the void of this reposition. Despite the intervention of the City in the form of public works housing projects, the remaining housing stock continued to decay causing many buildings to be abandoned and foreclosed. The density of Harlem was affected and by 1987, 65 percent of the buildings were owned by the City of New York, and many had become empty shells, conveniently available for drug dealing and other illegal activity.

After four decades of decline, Harlem's population bottomed out in 1990 due to inhabitable housing and deterioration of buildings. As an attempt to relieve some of the issue, fierce crime fighting and a concentrated effort to revitalize the retail corridor on the main thoroughfare of $125^{\text {th }}$ Street, was put into place. The number of housing units also increased, raising the property values of Central Harlem significantly. Empty shells and abandoned buildings began to sell and be revitalized as well. The demographic of the Greater Harlem neighborhood experienced a dramatic change and the African American community ceased to be the majority of the population, attributable to the rapid arrival of new white and Hispanic residents, marking an age of gentrification still felt in the area today. 


\section{$T H E$ S I T E : \\ ROBERT F. WAGNER HOUSES}

Senator Robert F. Wagner Houses is a public housing development Eastern Harlem, occupying a site between East 120th Street, East 124th Street, FDR Drive and Second Avenue. The development was completed on May 31, 1958, and was named after Robert F. Wagner Sr., as well as a monument on site that is dedicated in his name. Robert F. Wagner Sr. served four terms as a senator of New York State, was one of the chief leaders in directing New Deal legislation, particularly the acts establishing the National Recovery Administration in 1933, the National Labor Relations Board in 1935, social security, and the U.S. Housing Authority in 1937. In the 1940s he also sponsored bills calling for the extension of federal housing. Wagner was also Father to Robert Wagner Jr. who was elected Mayor of New York in 1953 and served three consecutive terms.
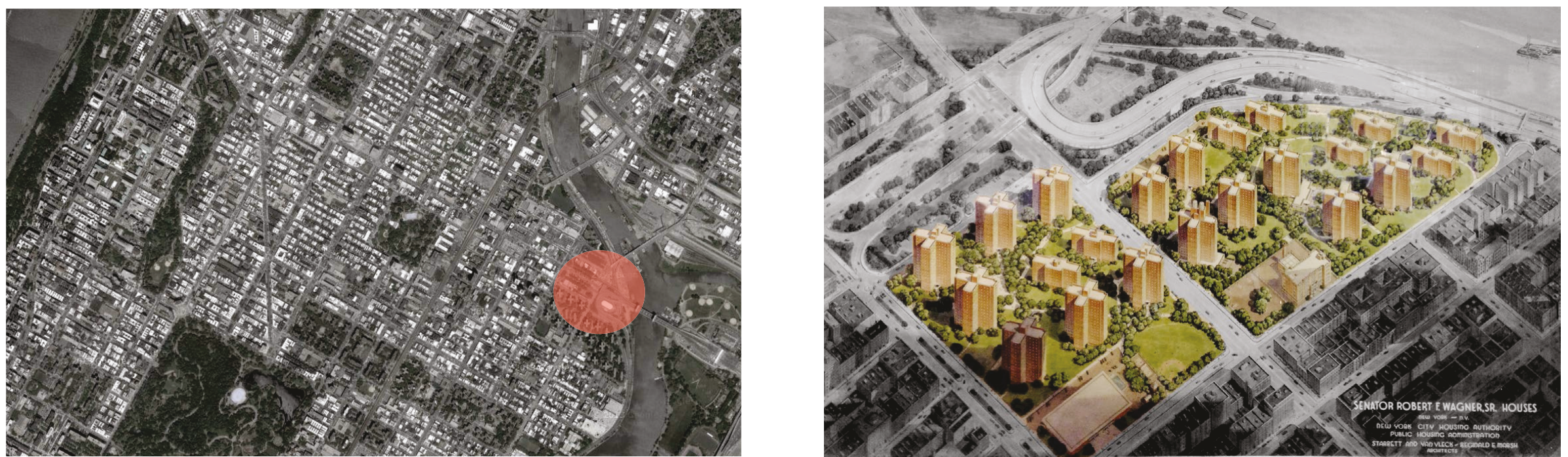

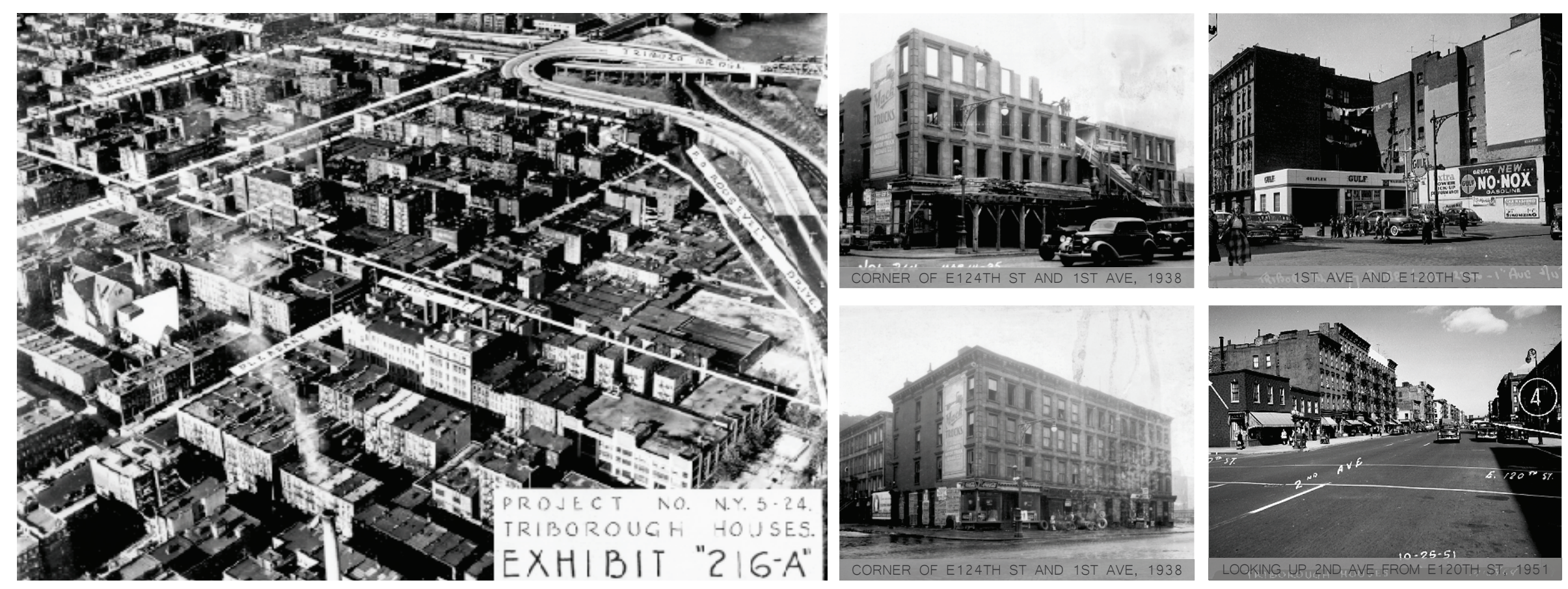


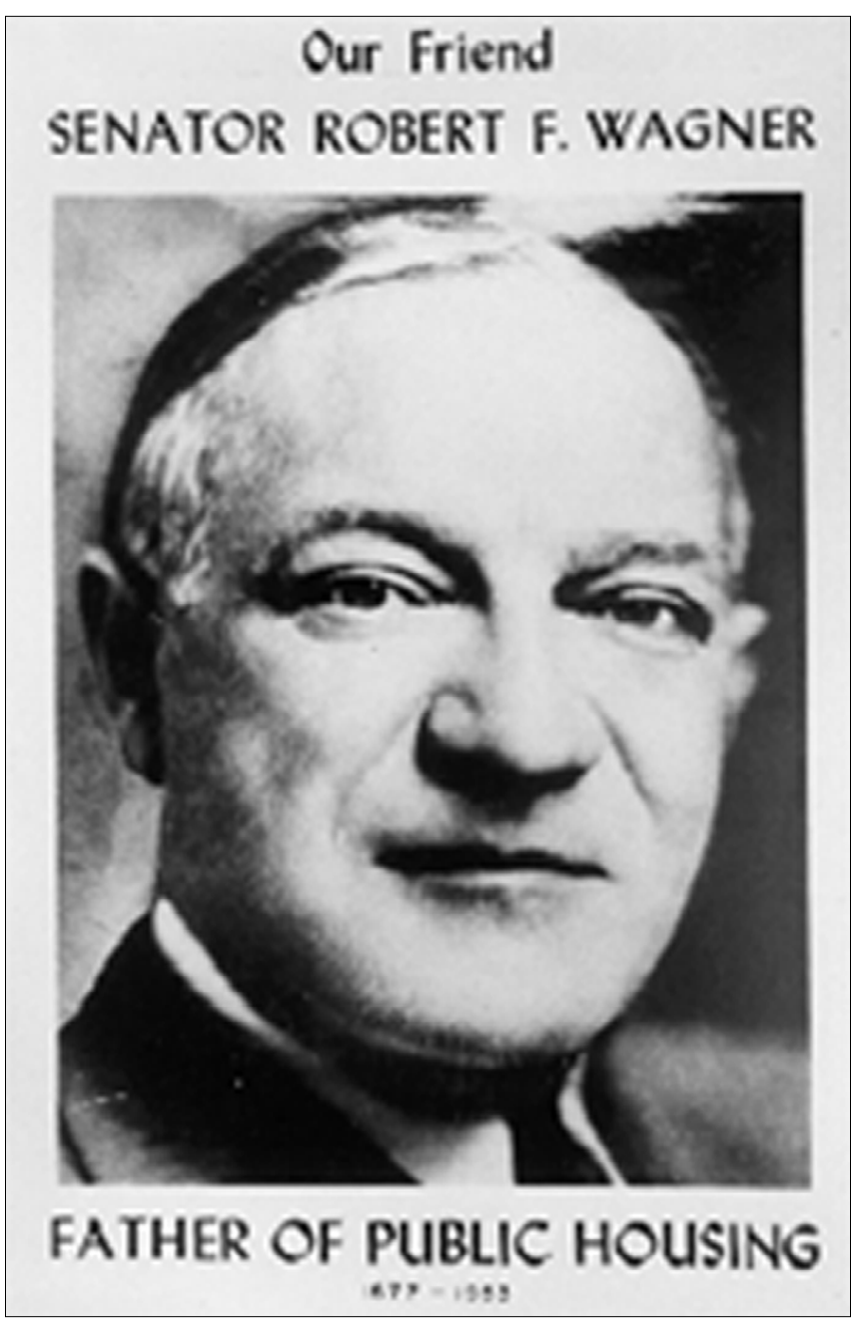

Senator Robert F. Wagner, 1877-1953, The "Father of 


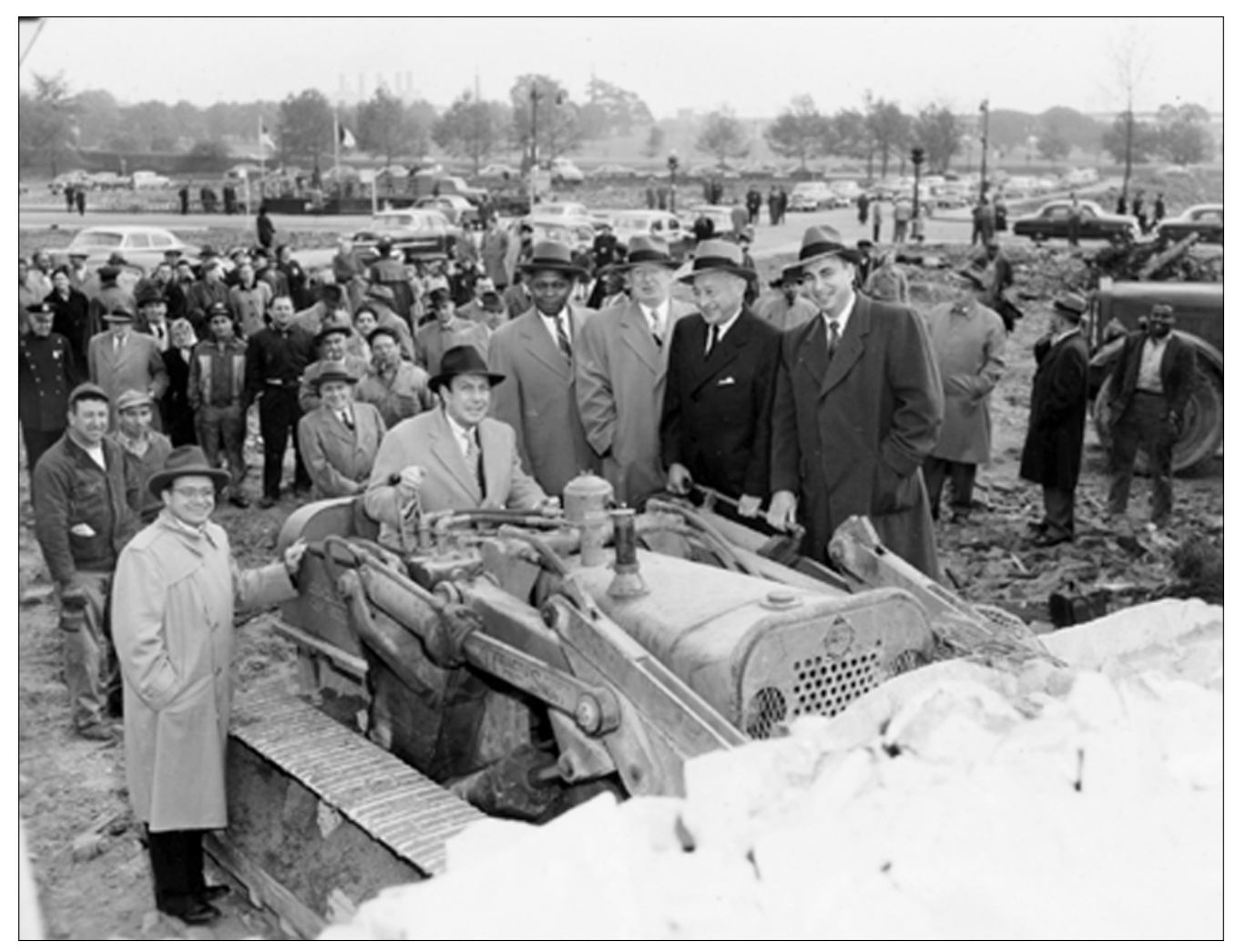

Mayor Robert F. Wagner poses on a bulldozer at the ground-breaking ceremonies for Wagner Houses in East Harlem, November 5, 1954. Originally designated as Triborough Houses, the project was renamed to honor the mayor's father, Senator Robert F. Wagner (1877-1953), who served (1927-49) in the U.S. Senate. Prints from the Housing Bulletin for NYCHA employees 
The Wagner Houses was designed as collaborative effort between Reginald E. Mash Associates and Starrett \& Van Vleck. The complex is administered by the New York City Housing Authority, like many other housing complexes in Eastern Harlem and remains the largest property in Manhattan operated by the NYCHA. It consists of fourteen sixteen-story buildings and eight seven-story buildings with a total of 2,154 apartments, ranging from one-bedroom to three-bedroom as well as handicap accessible units. In total, the Wagner Houses are home to approximately 5,300 residents, on a 26.91 acre property, making for very dense living. The complex follows the post WWII modernist mass housing model of the towers-in-the-park, leaving much of the ground surface area open for pedestrian use. The property occupies a superblock site, dissolving the gridiron of the Manhattan Street composition. The internal spaces of the complex are landscaped, however mostly fenced off from resident use.

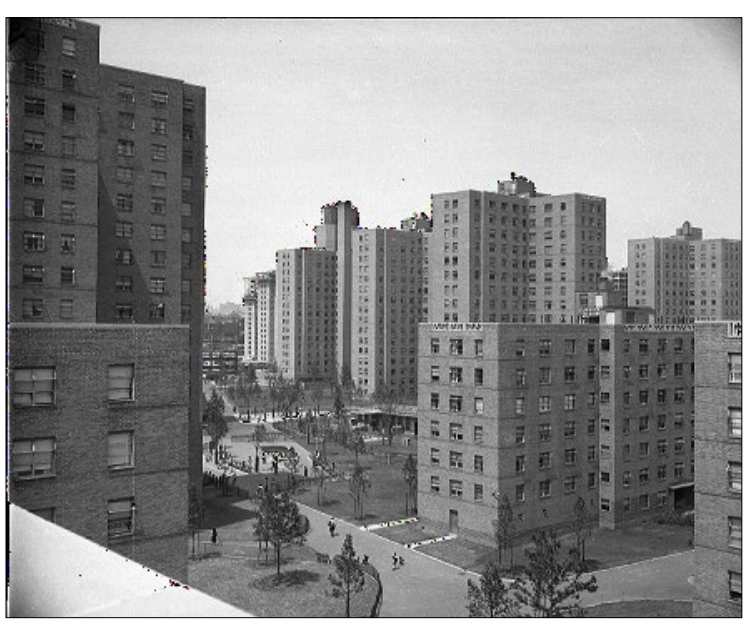

A view of the Wagner Houses under construction
(08.08.1957). Photo from the La Guardia
Wagner Archive of La Guardia Community College.
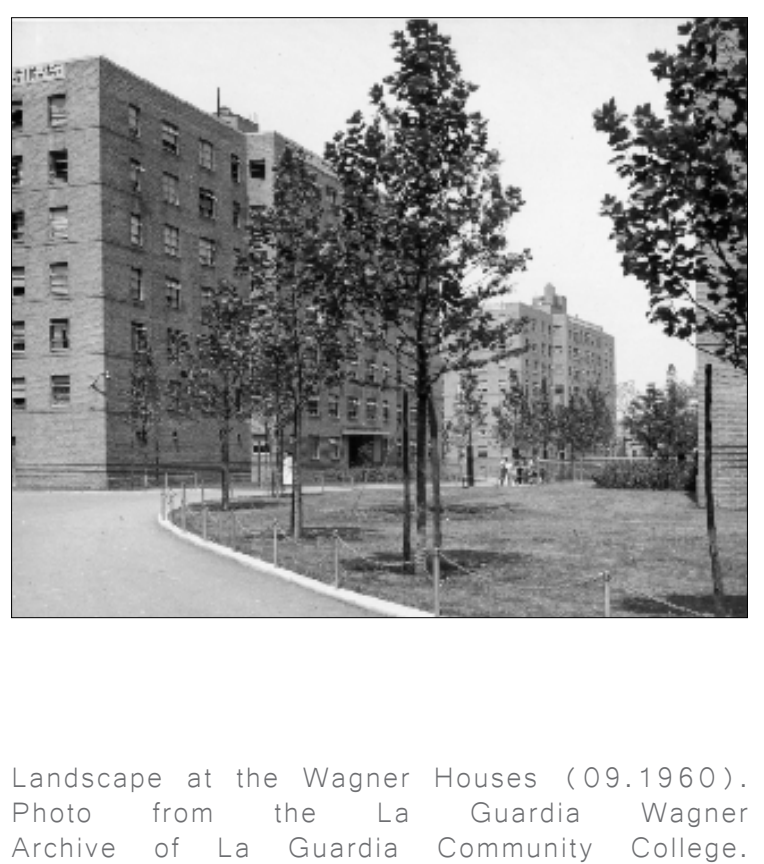

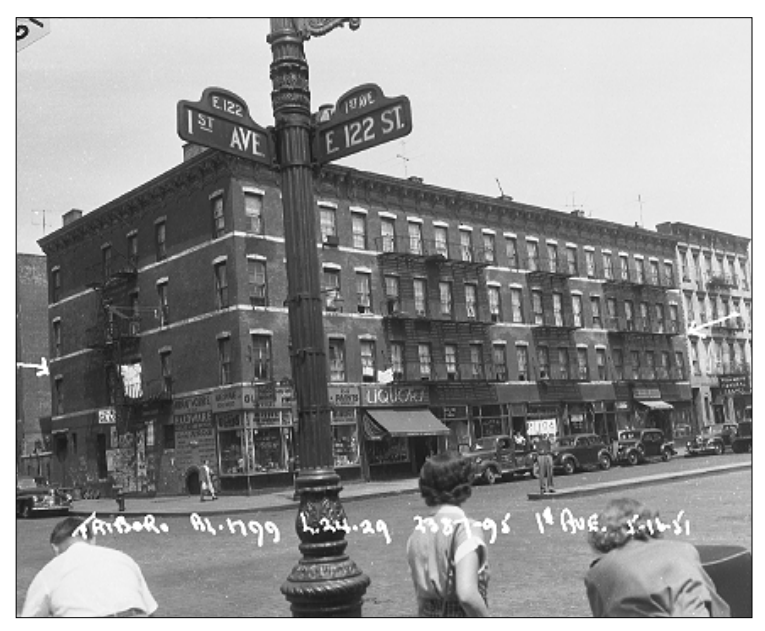

Site originally designated for the Wagner Houses (05.16.1951).Photo from the La Guardia Wagner Archive of La Guardia Community College. 

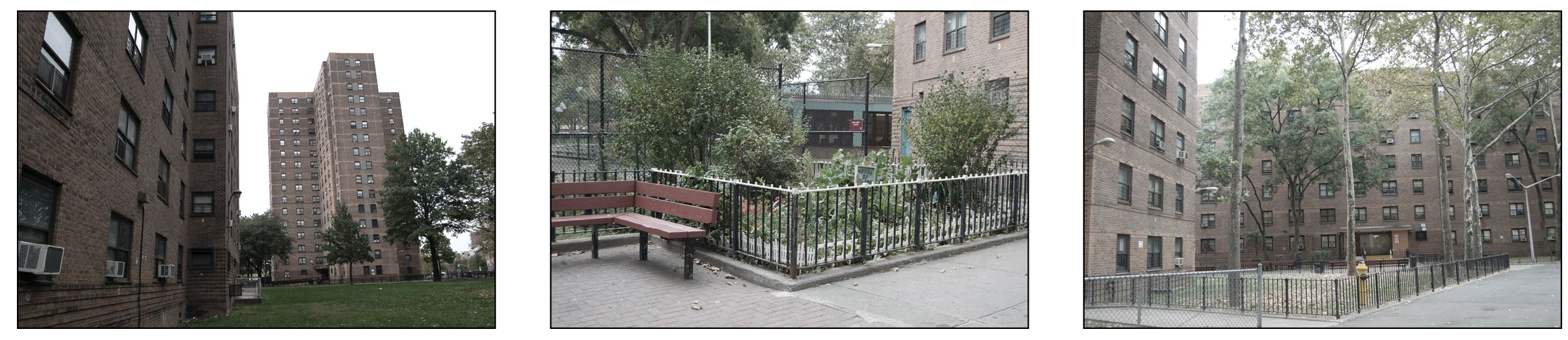
he living conditions within the units, in regards to space and hygiene, are quite adequate; however, the site provides no amenities to support its residents. The units are provided with the basics, such as a refrigerator and a stove. Following the ideologies of post-WWII social housing of the mid-twentieth century, the development caters to the need for housing of the two parent nuclear family, which was the prevalent demographic of the time. In reality what is needed today is an appropriate environment to house and support such family dynamics as a single mother with child care needs, making the housing model somewhat outdated. With the demographic of the complex being low-income, many tenants do not have extended family or support systems to rely on and would benefit from on-site amenities.
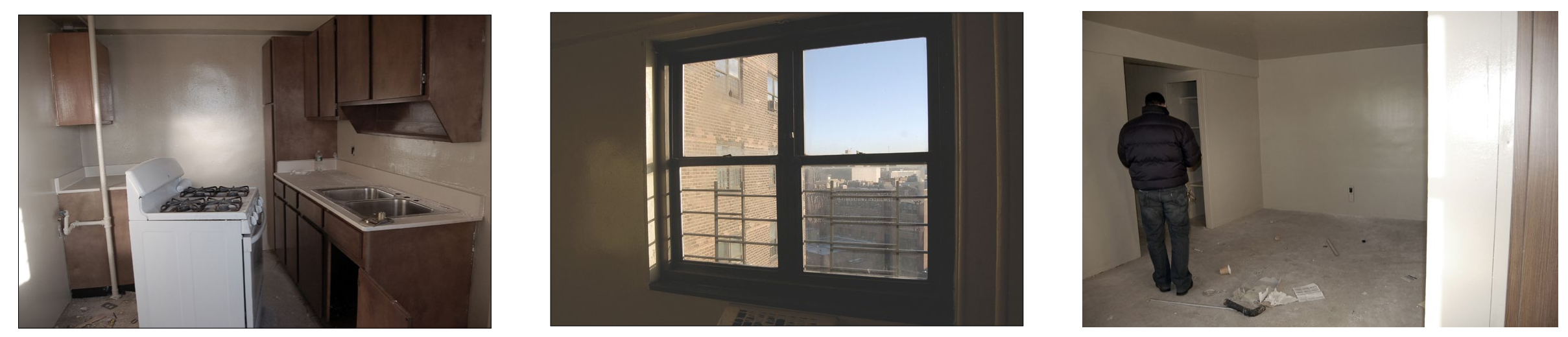
The Wagner Houses falls under the jurisdiction of Community Board 11 of East Harlem; an organization of community members involved in shedding light on the successes and weaknesses of its community as well as promoting awareness on possible improvements. As the neighborhood continues to grow, it is important to Community Board 11 to assess the needs of the people, schools, hospitals, museums, parks, community centers and all of the elements that are a part of a community. With those things in mind, Community Board 11 puts together an annual Statement of District Needs that is submitted to the Mayor's Office in order to identify what the community wants city agencies to consider as they develop their budgets. The Statement of District Needs also guides local community based organizations in their efforts to secure resources that address the identified needs. 


\section{NOTES}

33. Roi Ottley, and William J. Weatherby. The Negro in New York; an Informal Social History (New York: New York Public Library, 1967), 181.

34. Larry A Greene, "Harlem in the Great Depression, 1928-1936" (Ph.D. Diss., Columbia Univ., 1979), 5.

35. Nat Brandt. Harlem at War: The Black Experience in WWII (Syracuse University Press, 1996), 24

36. Nat Brandt. Harlem at War: The Black Experience in WWII (Syracuse University Press, 1996), 26

37. Richard Plunz. A History of Housing in New York City: Dwelling Type and Social Change in the American Metropolis (New York: Columbia UP, 1990), 182.

38. Deirdre Mullane, ed., Crossing the Danger Water: Three Hundred Years of AfricanAmerican Writing (New York: Doubleday, 1993, 479

39. David Levering Lewis. When Harlem Was in Vogue (New York: Knopf, 1981), 27. 40. Hilary Ballon and Kenneth T. Jackson. Robert Moses and the Modern City: The Transformation of New York. (New York: W.W. Norton \&, 2007), 82. 
"The chief purpose of public housing is to make better and healthier citizens by giving them a decent place to live, and especially providing proper surrounds for children" 
chapter three

REVITALIZATION:

LEARNING FROM THE WAGNER HOUSES

The Robert F. Wagner Houses possess qualities to support concepts of effective public housing, with its waterfront property, in Eastern Harlem, as well as it low percentage of ground coverage to promote pedestrian circulation. There is a theory, however, that speaks against the dissolving of the New York City gridiron to implement a tower-in-the-park, superblock complex to house lowincome residents. It speaks to the idea that the "park" reinforces the tower as a secure residential fortress; but in lower-income housing complexes it also symbolizes the antithesis of security, containing rather than protecting its tenants. Housing of this nature has led to a concentration of poverty in one community, resulting in lack of surveillance and the growth of negatively impacting externalities.

The Wagner Houses accommodates over 5,000 residents, which is comparable to the population of a small municipality. The complex operates with no amenities available for tenant usage, causing residents to travel elsewhere to utilize their daily resources and recreational facilities and giving rise to a lack of connection and respect to the physical structure that houses them. Housing designed for the mid-twentieth century nuclear family no longer suits the need for supportive services of low-income residents of today. Housing developments such as this should provide recreation for the surrounding community as well as residents of the complex. The development of low-income housing is an opportunity to provide additional amenities; packaging housing with public services and recreation to create real homes in the community that residents can 
take pride in. Using the scale of the superblock, the intervention on the Wagner Houses will be a revitalization, instead of a reconstruction; giving the residents a sense of ownership and propriety to community they belong to.

As an agent for Community Board 11 of East Harlem, I propose to implement an appropriate network of on-site resources that will support the residents of the Wagner Houses. The program is developed through a network that the community, the family, and the child all belong to. Three major programmatic elements have been selected with respect to leading discussions held in several Community Board meetings, which I have attended. The first is a facility geared towards the well-being and safety of the child. This service will take form in the Practice Makes Perfect_Foundation, providing a site for its first location in Manhattan. Practice Makes Perfect is an organization that works

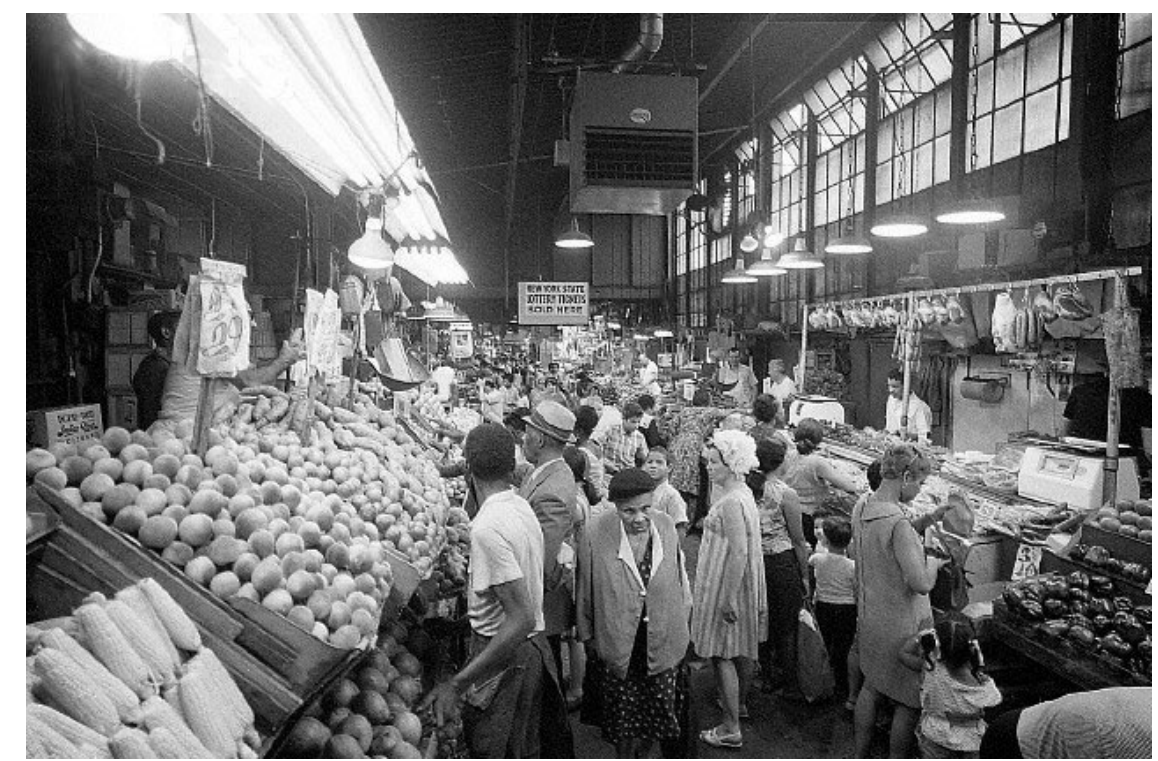

- La Marqueta in its heyday in the 1960 s. Photograph from La Marqueta History to narrow the achievement gap in low-income U.S. neighborhoods through enrichment programs that pair skills development for younger students with leadership and career training for older students. The second programmatic element is identified as a medical facility endorsed by PACE, a Program of All-inclusive Care for the Elderly. Pace provides an alternative nursing placement for the elderly and people with diagnosed illnesses that do not necessarily need to be admitted into nursing homes or hospitals. The philosophy of the program is to maintain participants in the community for as long as medically and socially feasible, to maximize their independence and enrich their quality of life by optimizing their functional ability. The third intervention will be driven by East Harlem's strong cultural community in the form of a Cultural Center and site for La Marqueta. Originally under the Metro North tracks between $111^{\text {th }}$ and $116^{\text {th }}$ Street, La 
Marqueta has dwindled in size almost to the point of non-existence, due to lack of feasible real estate and a suitable business model. The substantial Hispanic community in East Harlem continuously puts forth effort to keep it alive and the revitalization of the Wagner Houses proposes an appropriate venue for its continued existence.

The final proposal for the revitalization of the Wagner Houses is to develop the threshold between the dwelling unit and the community. After visiting several units within the high-rise apartment tower, it is clear that the living condition within the personal space of the units is desirable but instead it is the indoor common space that is lacking through the corridors and circulation cores. The proposed solution to this is to develop the space that bridges public and private entities; the entrance. By enhancing the experience at the entrance of the building, a threshold is created between the dwelling and the now meandering of public facilities on-site.

Not to disturb the integrity of units in the towers, the intervention on the property will be a low-rise design, never reaching over one or two stories. The program will utilize the large amount of empty ground space on the superblock to ribbon through the site, reintegrating the gridiron of the New York City street. The proposed programmatic elements will feed off of this ribbon of circulation, and will propagate from its modular and grid-like characteristics. The relationship between the public and private elements on the site will craft a sense of community and dialogue, ultimately enriching the everyday life inside the complex and allowing it to take on a greater role in the urban life of New York. 


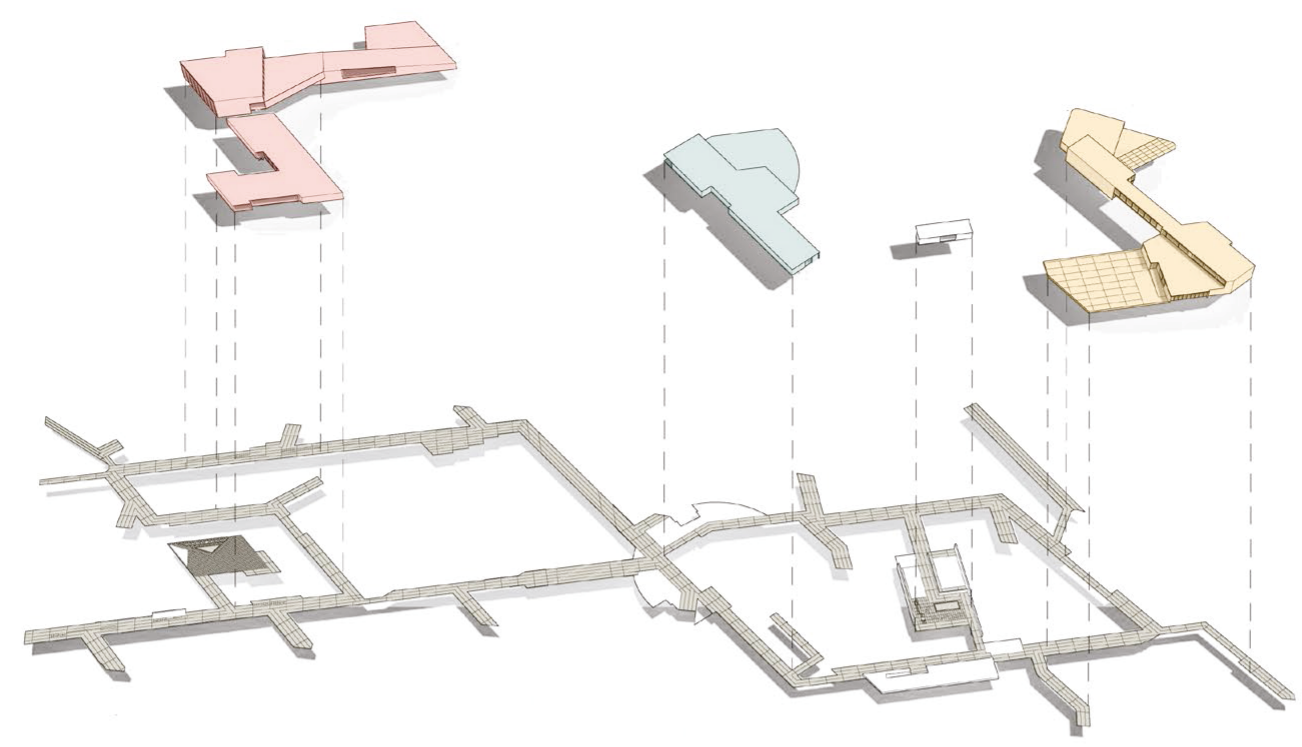

PROGRAMMATIC NTERVENTION

R I B B O N OF

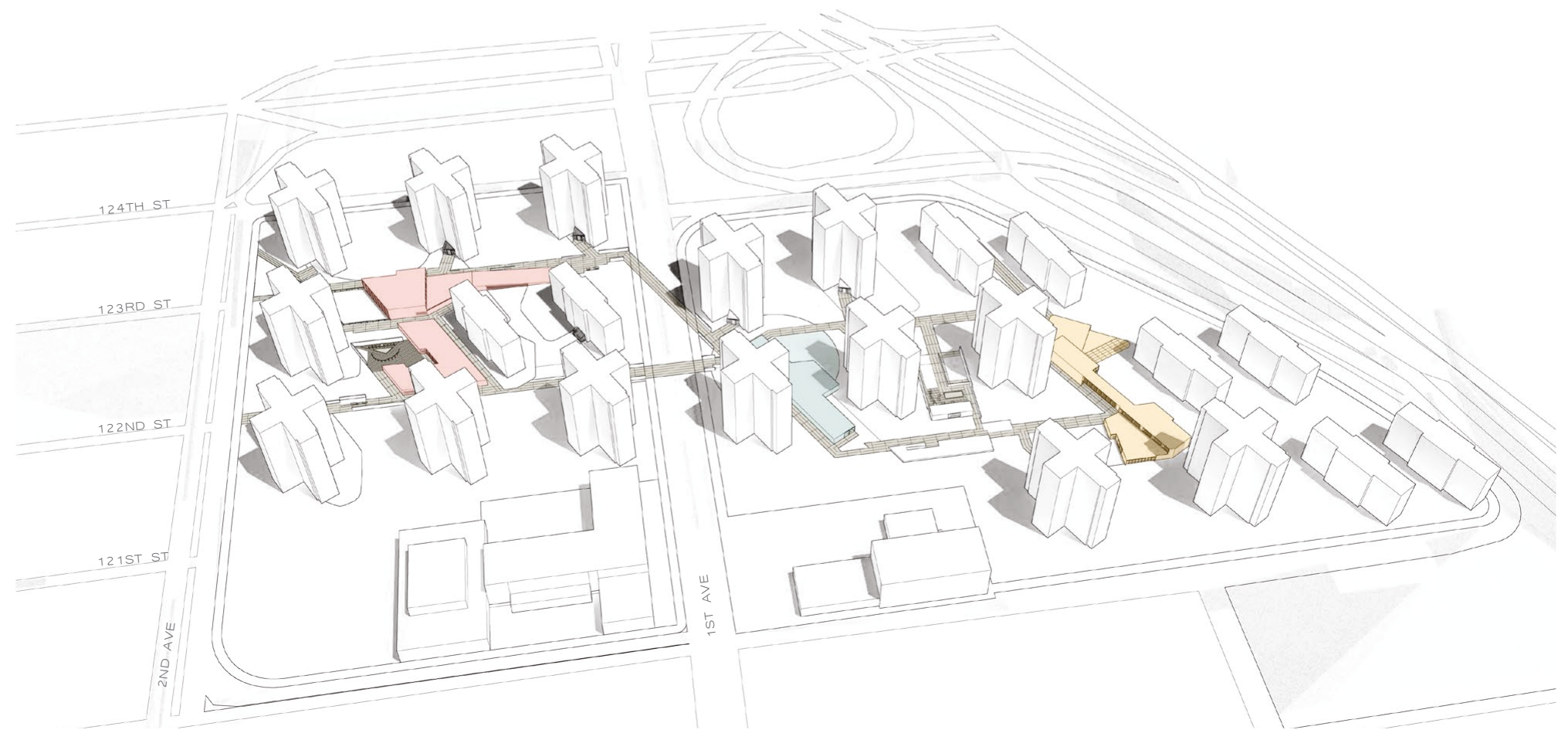

Practice Makes Perfect

PACE

La Marqueta and Cultural Center
The program will utilize the large amount of empty ground space on the superblock to ribbon through the site, reintegrating the gridiron of the New York City stree, while the proposed programmatic elements will feed off of this ribbon of circulation. 


\section{P R A C T I C E M A K E S P E R F E C T :}

AN ORGANIZATION THAT WORKS TO MARROW THE ACHIEVEMENT GAP IN LOW-INCOME

U.S. NEIGHBORHOODS THROUGH ENRICHMENT PROGRAMS THAT PAIR SKILLS DEVELOPMENT

FOR YOUNGER STUDENTS WITH LEADERSHIP AND CAREER TRAINING FOR OLDER STUDENTS

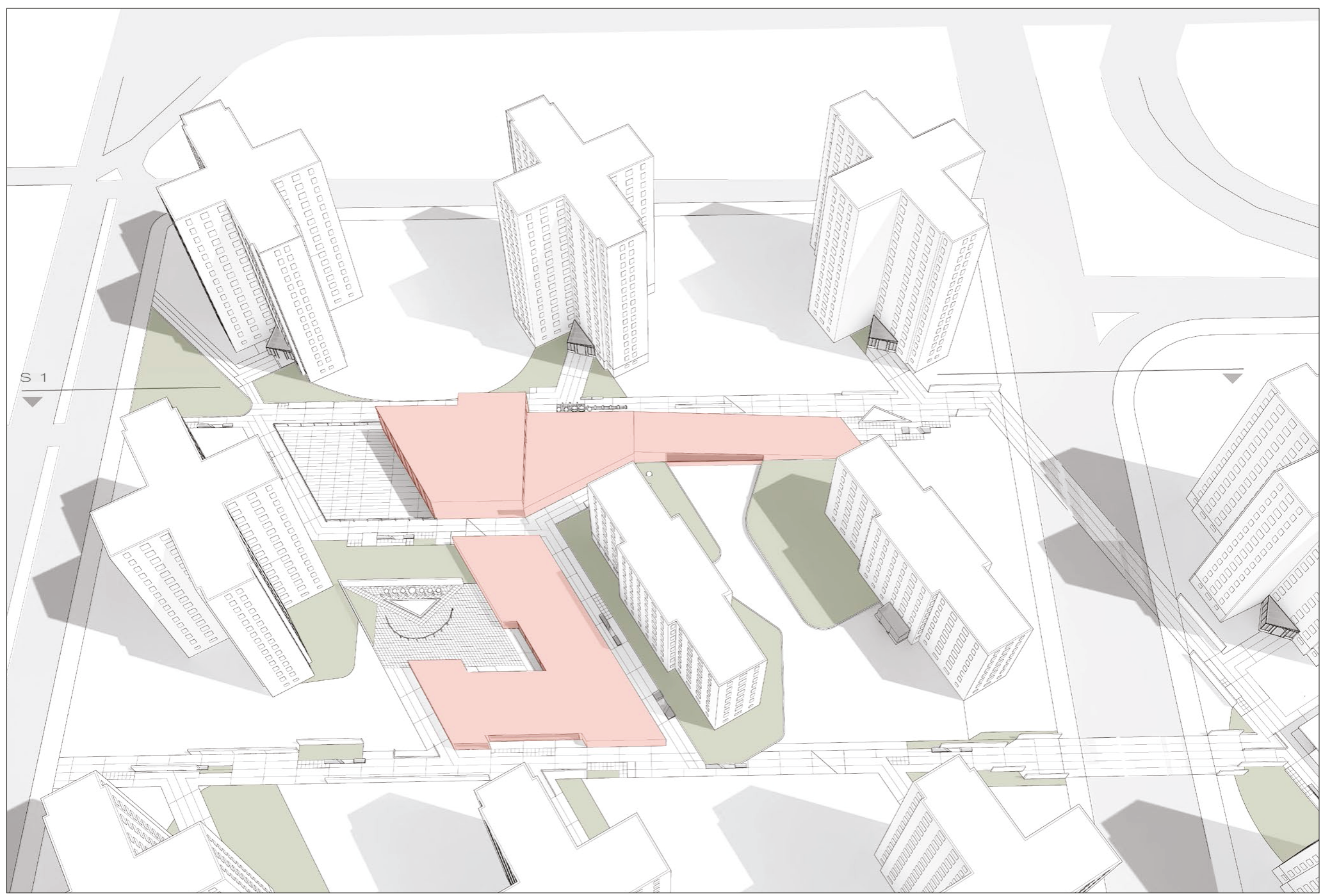

Practice Makes Perfect holds place as the first phase in physically implementing programmatic elements throughout the site. A particular language has been enforced through the design that will carry through into the following two programmatic phases. 


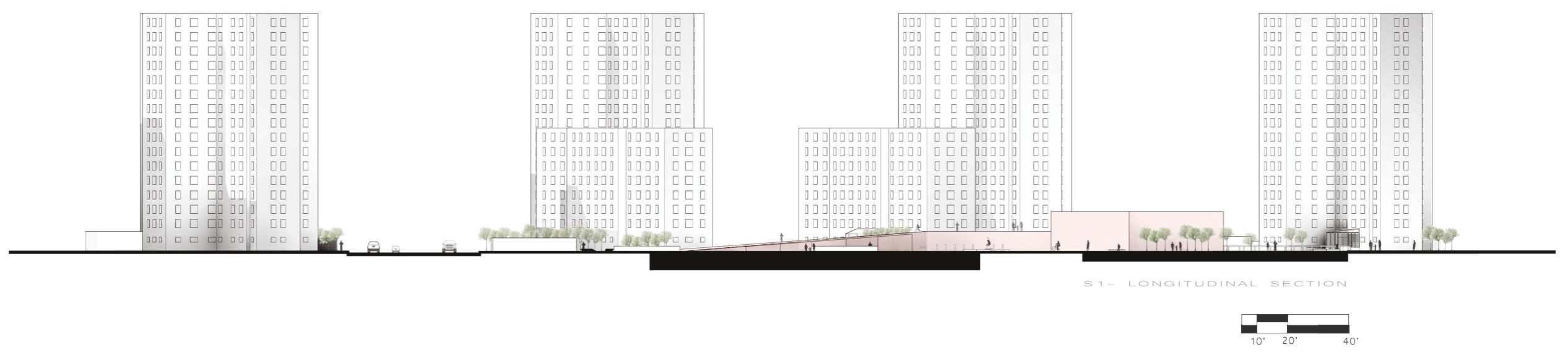




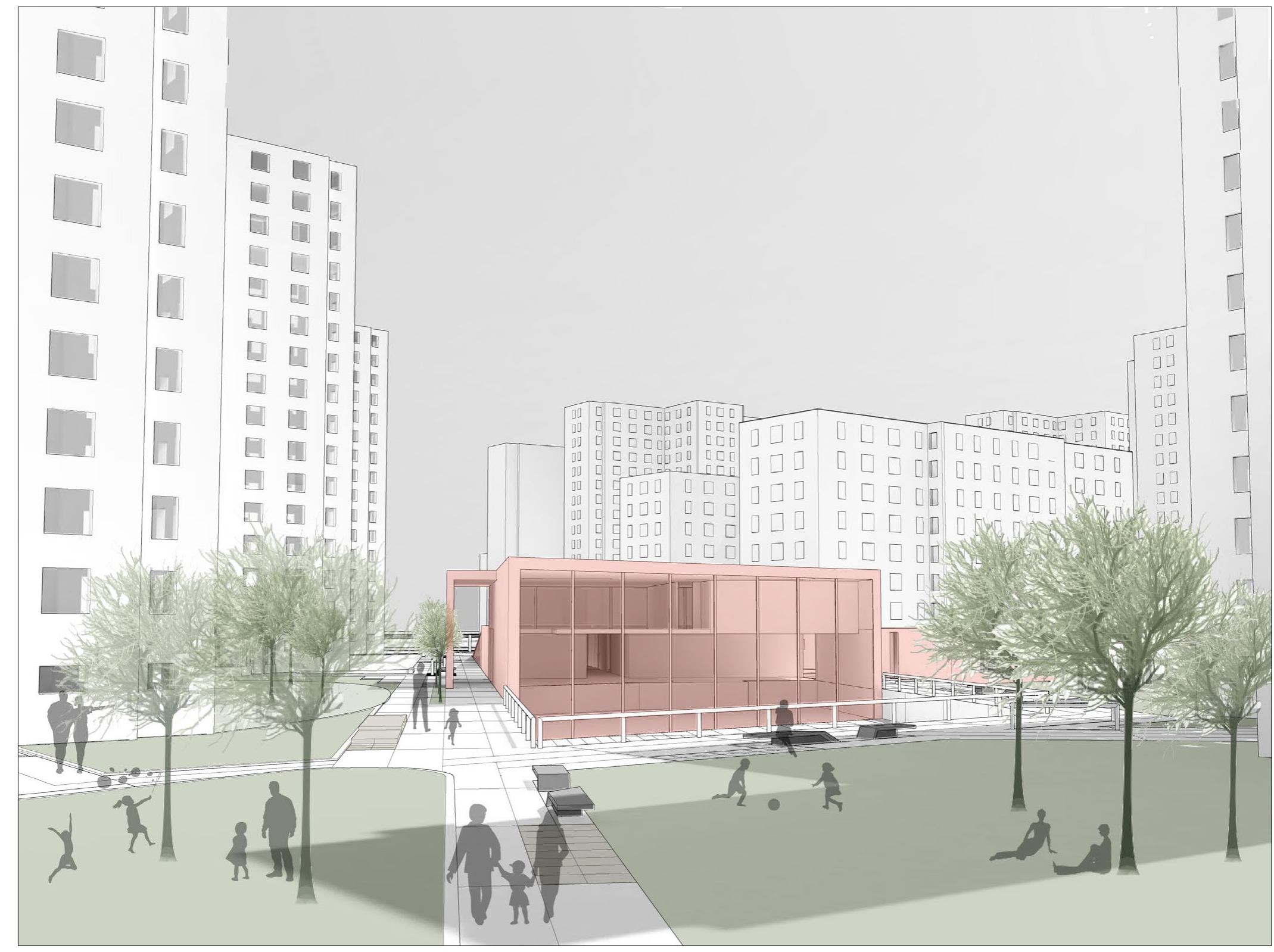

Residents occupying the ribbon of circulation around Practice Makes Perfect. 

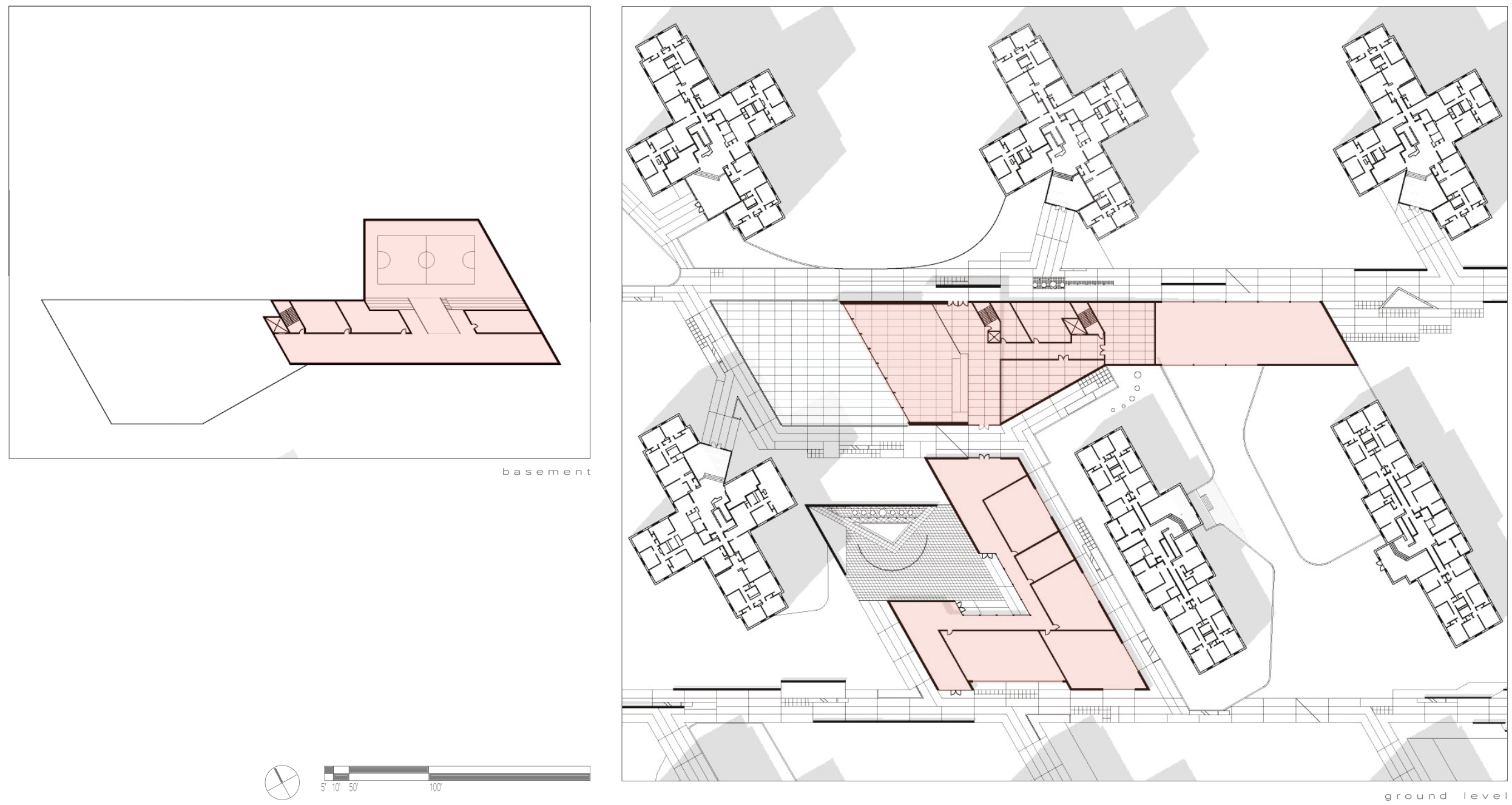


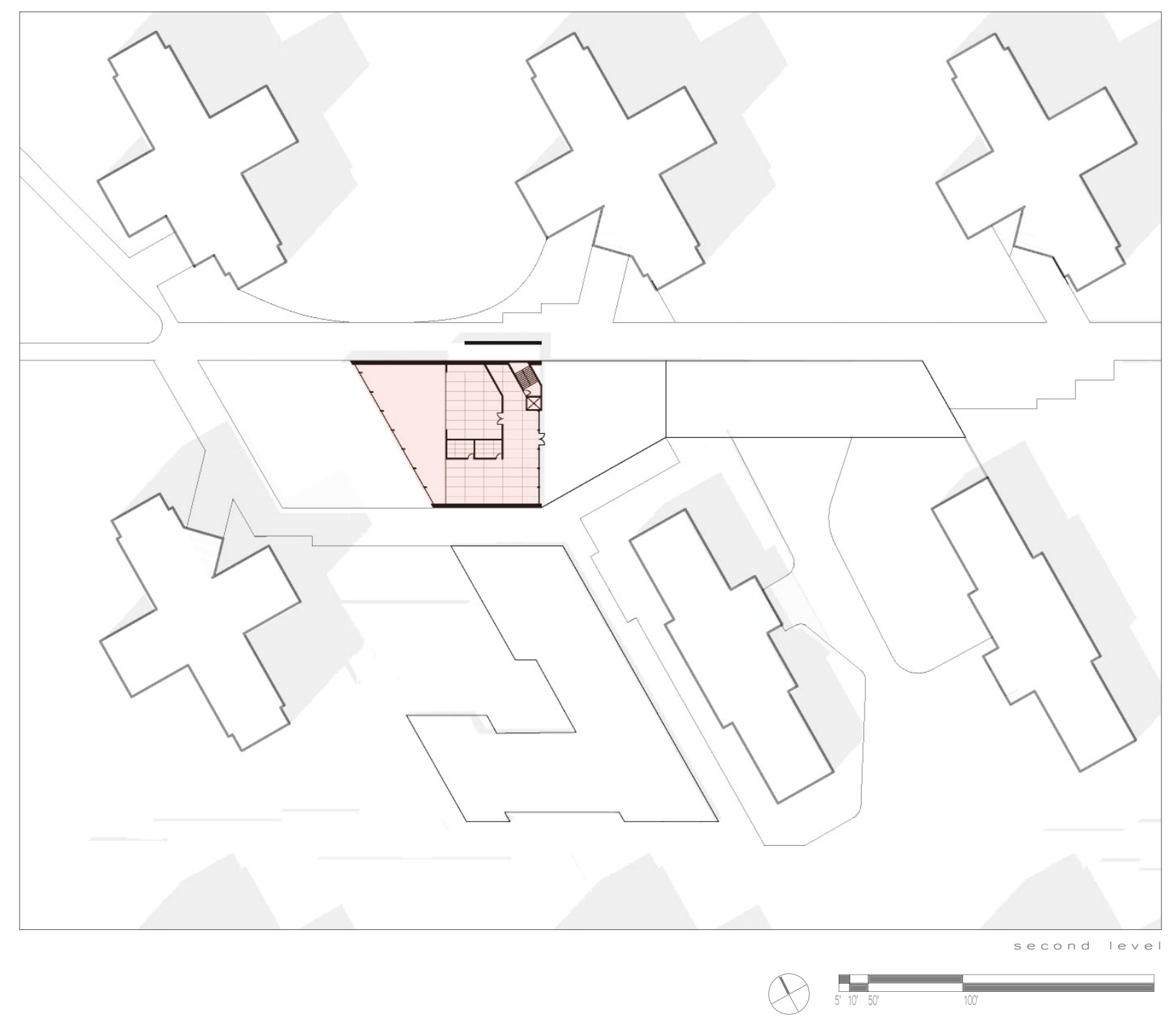



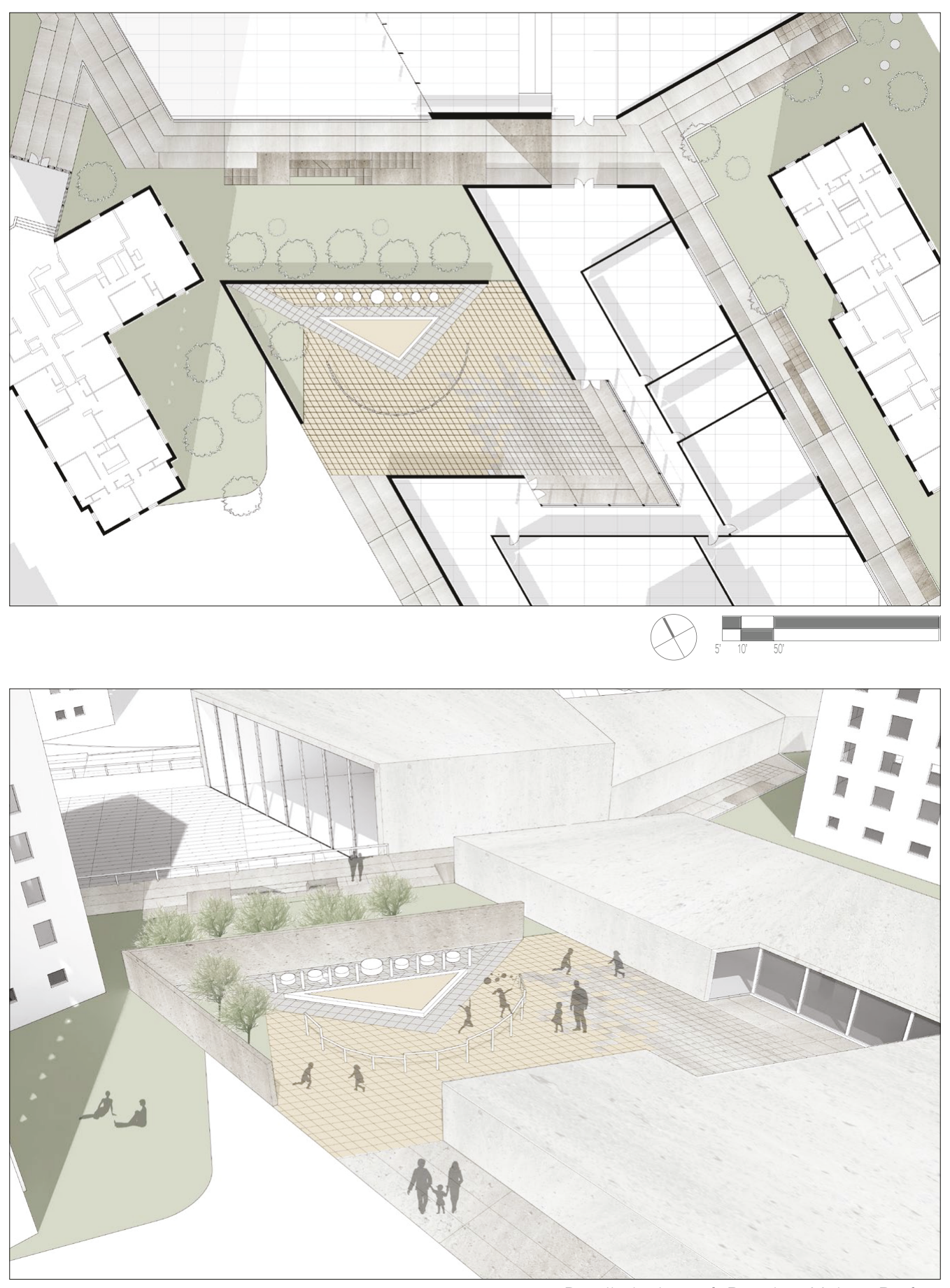


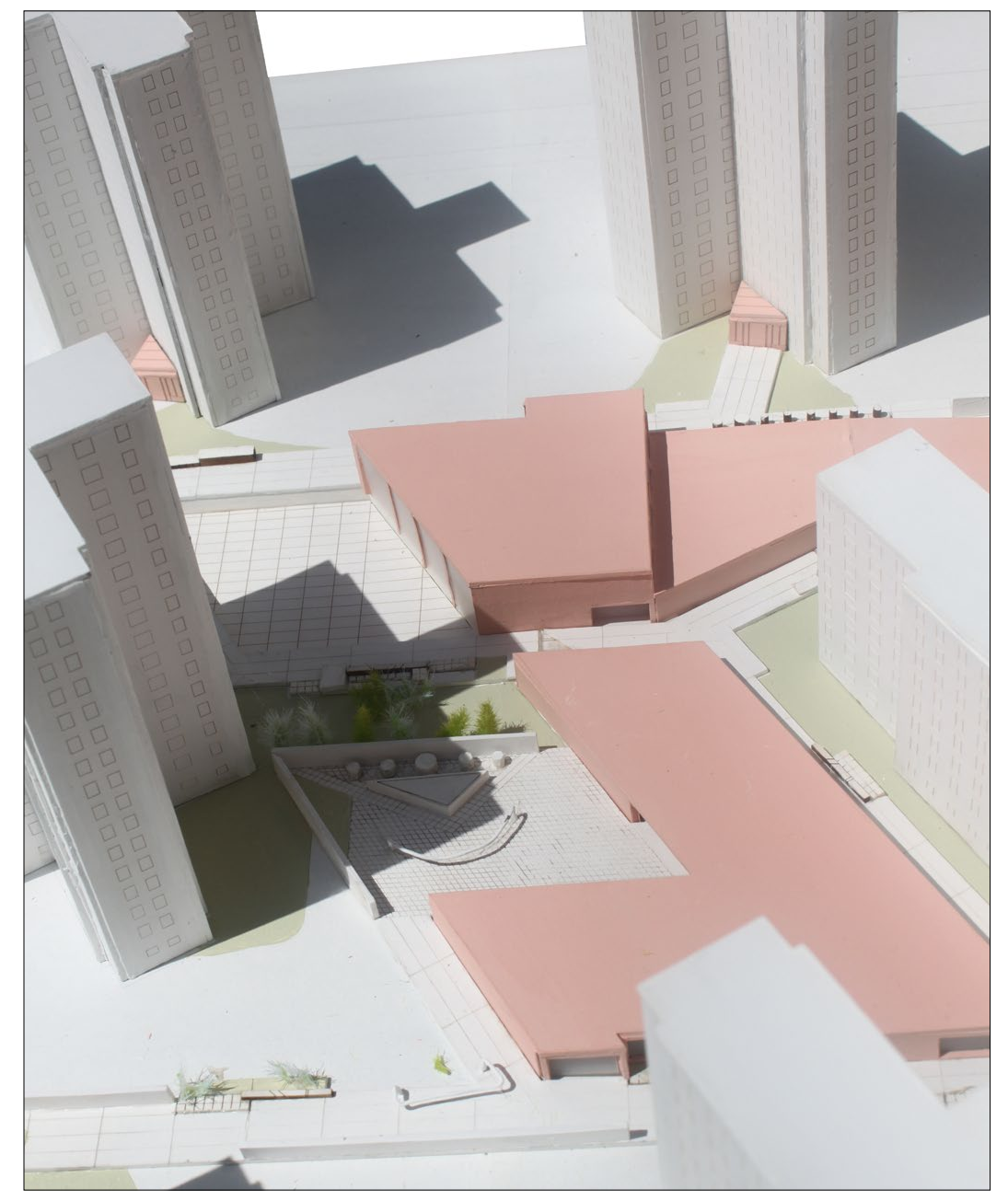

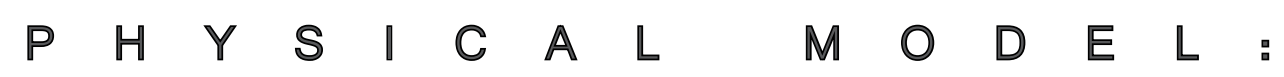
EXPLORATION OF PRACTICE MAKES PERFECT INTERVENTION

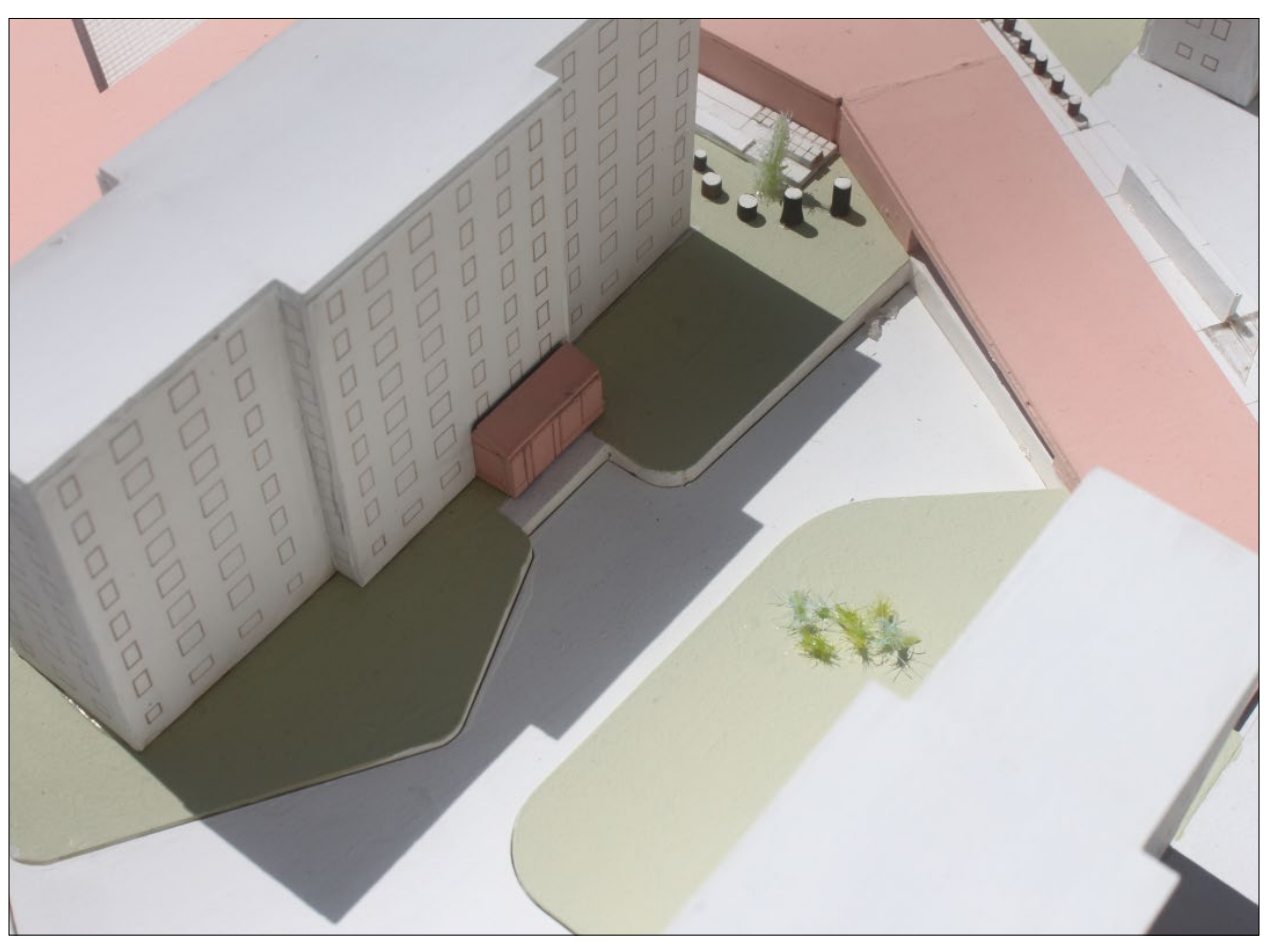




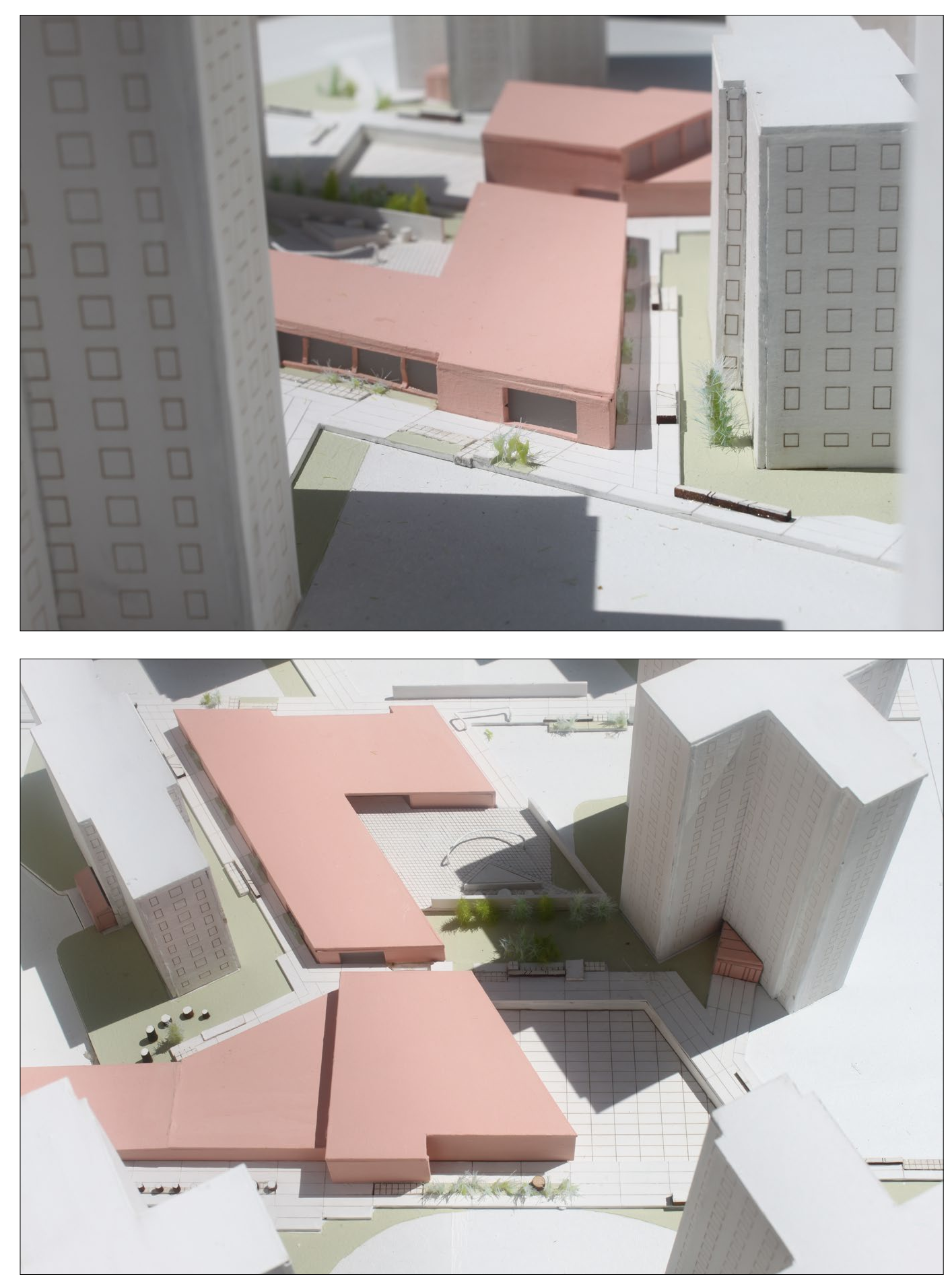



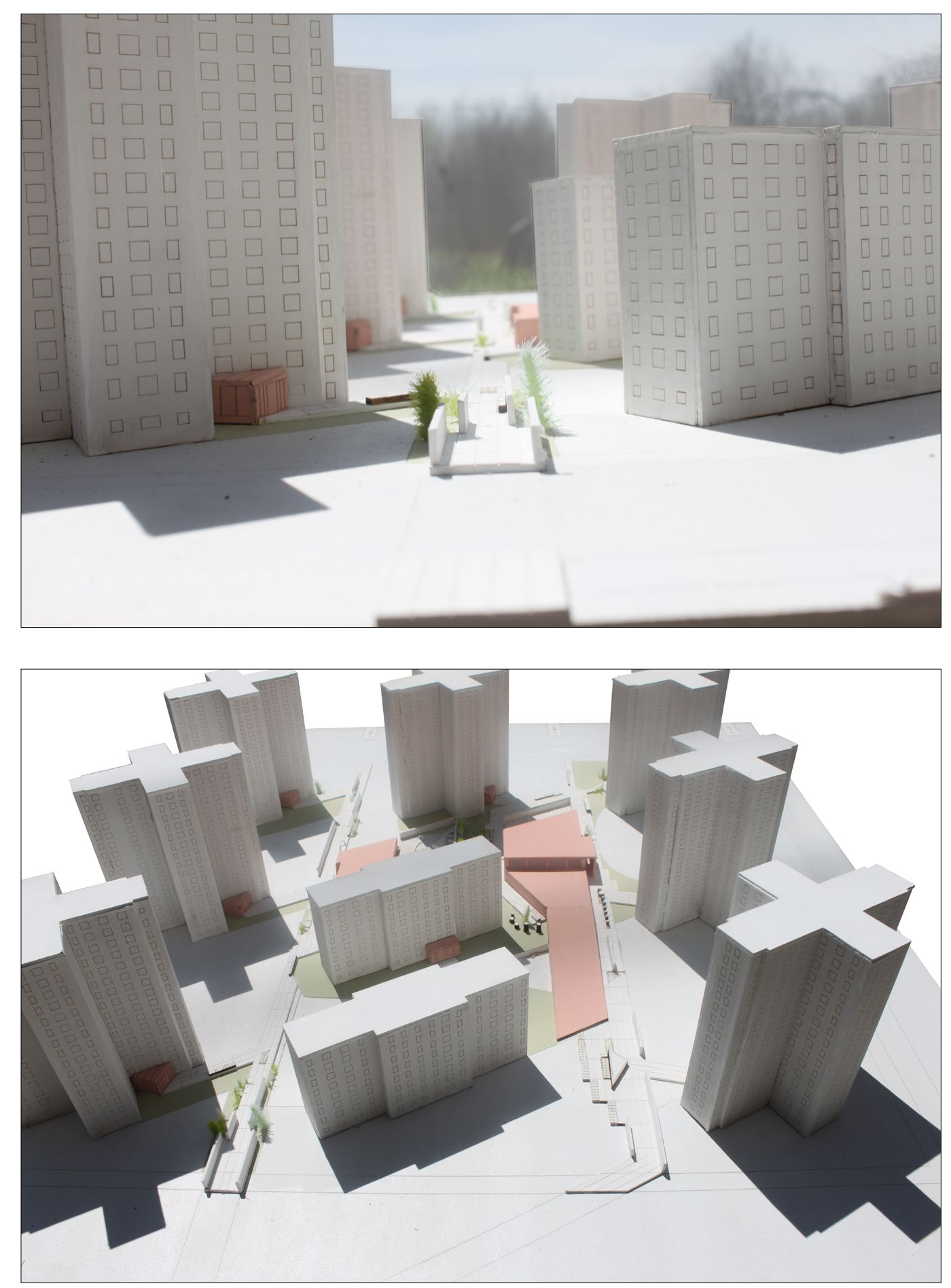


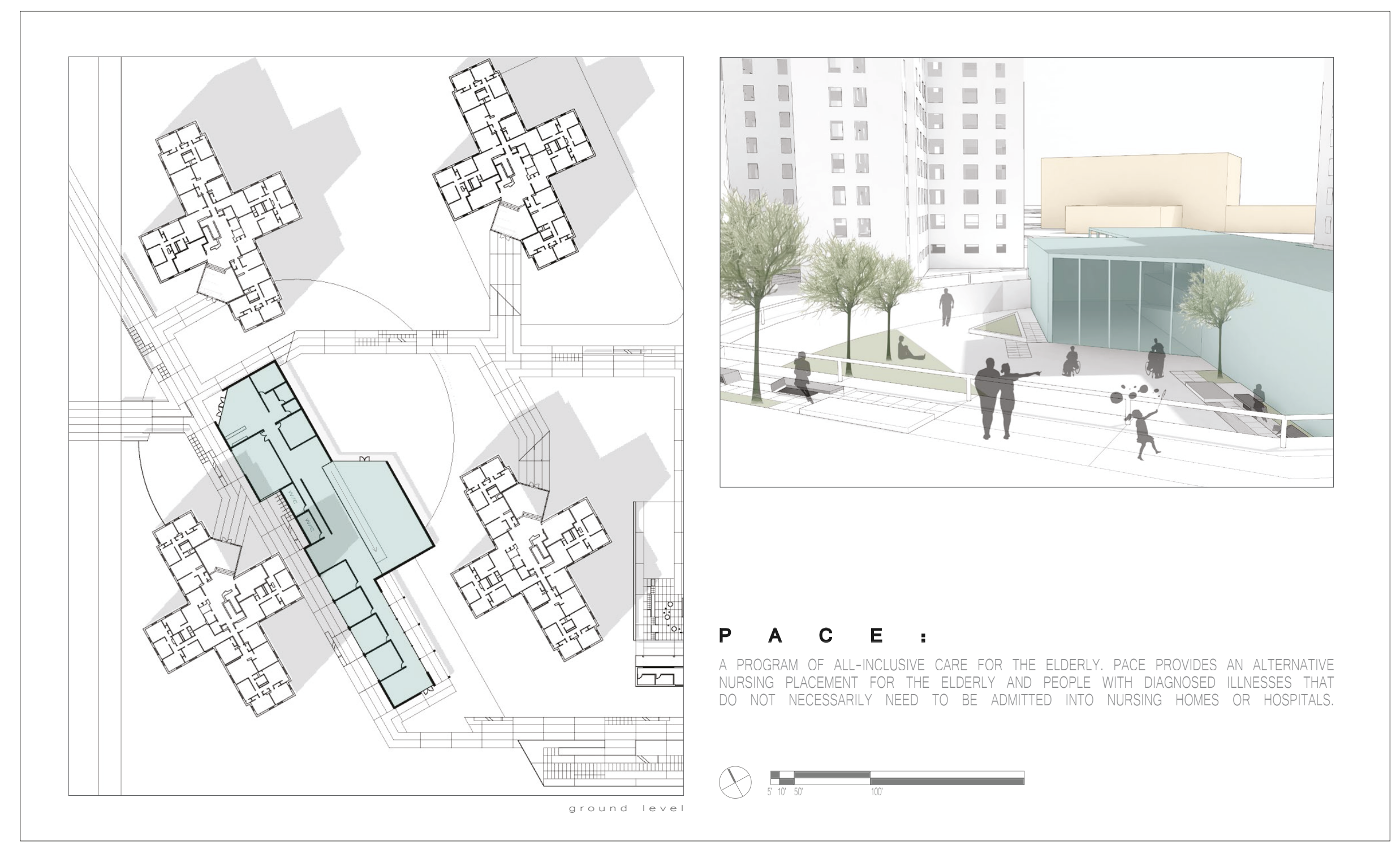




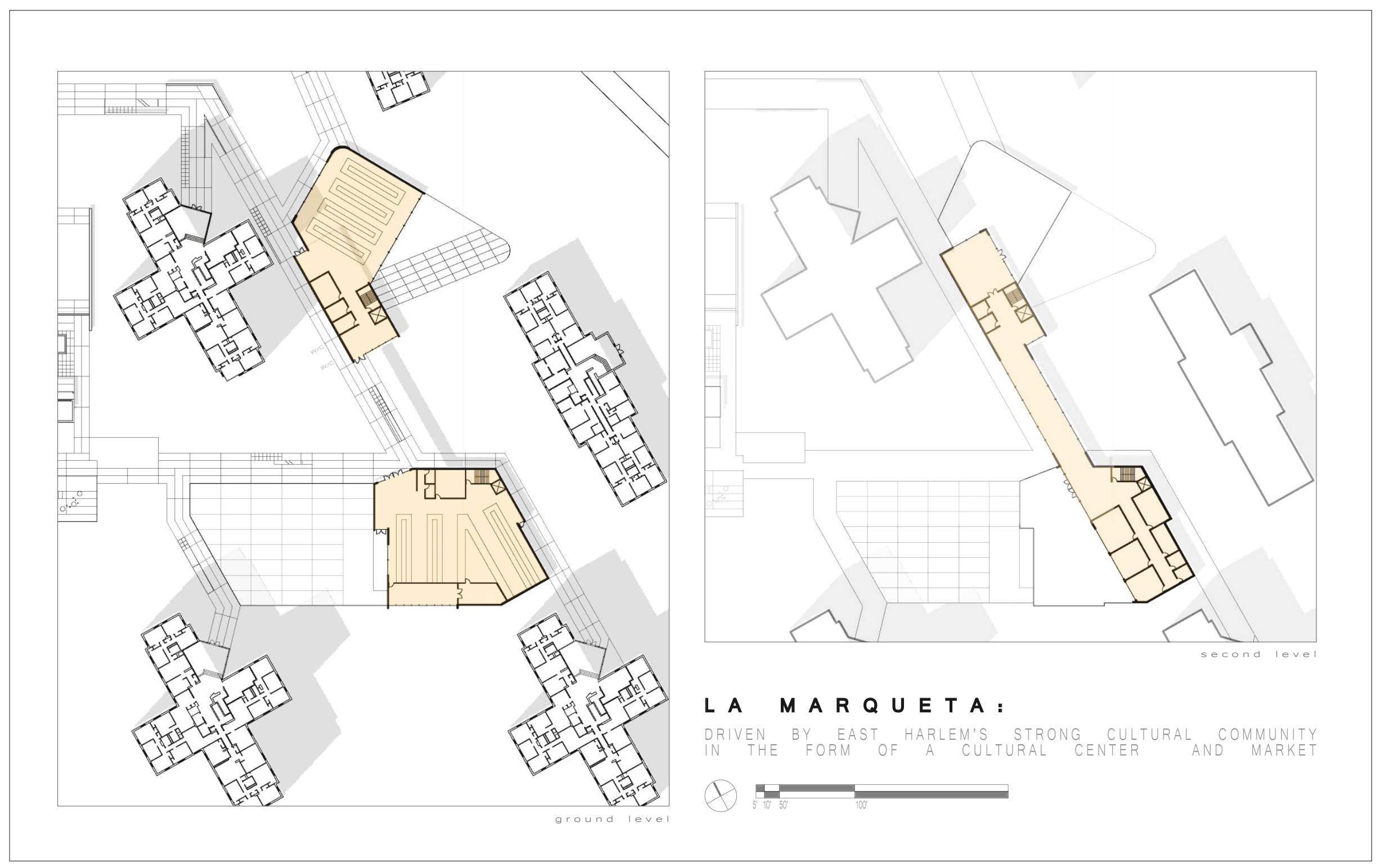




\section{KIT OF PART S :}

URBAN FURNITURE \& PAVING DETALLS

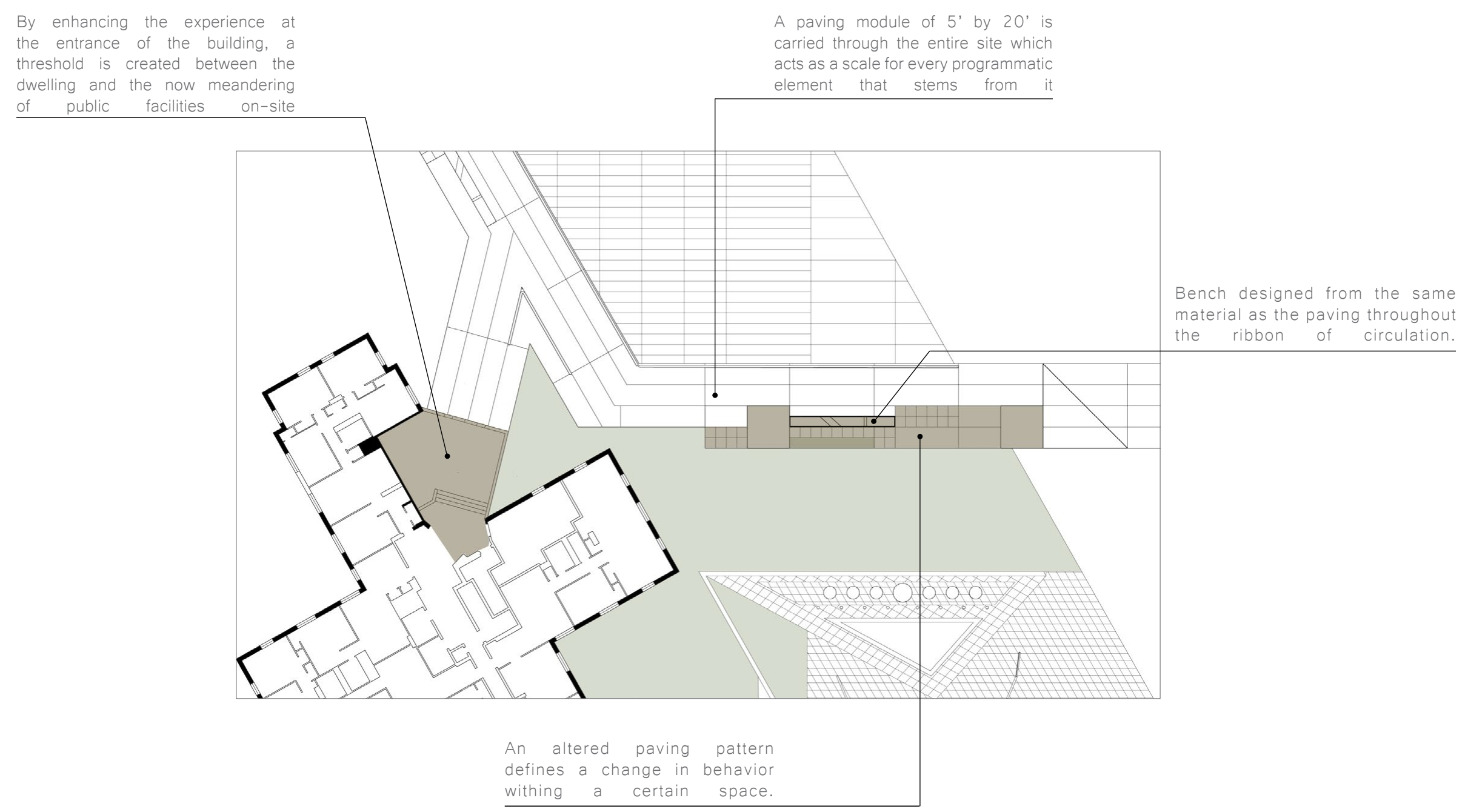



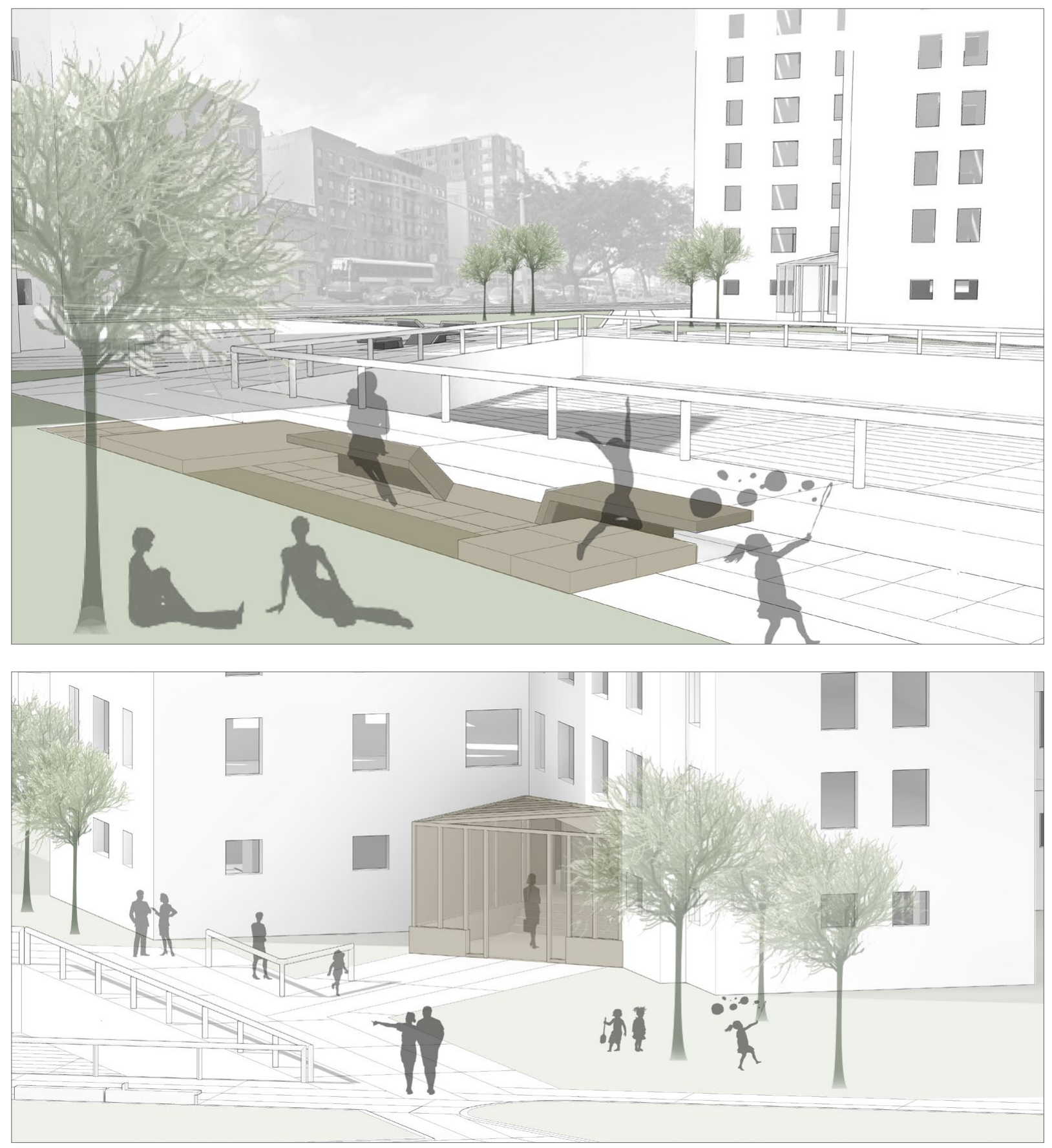
Through the development of housing typologies evaluated to house the large populations of urban metropolitan cities, citizens throughout history have felt the effects of such political and social intervening forces as the division of social classes and the effect of technological progression on the experience of the dwelling. Looking at the population growth of New York City since the mid-nineteenth century, factors such as these have proved paramount in the shaping of the city in relation to housing its people. The exploration of this thesis has aimed to shine light on individual moments in time and specific case studies relevant to the evolution of housing and the growth of the city itself. The ideologies connected with modernist mass housing have sustained a significant presence through New York City's process of growth and have participated in physically and socially segregating different ranks of social classes. Understanding that the movement of mass housing has brought forth related such terms as social housing, affordable living, and public housing is vital in defining the shortcomings and opportunities this housing model.

In many cases, housing of this type has become a model of last resorts, causing concentrated poverty in one community and leading to several negative externalities. Through the consideration of the Robert $\mathrm{F}$. Wager Houses, in Harlem, New York, I have proposed packaging the existing housing with public amenities and recreation to create 'real homes' in a community that people can take pride in. The proposed 
intervention will give the residents of the Wagner Houses a sense of ownership within their community and the opportunity to value familial propriety. Through the design it was important to take into account the individualities of the demographic, for example the path of the child, being that each belongs to a complex network that acts as a support system in order to nourish their growth and that of the community. All together the revitalization of the Wagner Houses will enhance the experience of daily life with the complex and strengthen its role within the urban fabric of the city. 
Arendt, Hannah. The Human Condition. Chicago: University of Chicago, 1958.

Baker, Paul R. Richard Morris Hunt. Cambridge, MA: MIT, 1980.

Ballon, Hilary, and Kenneth T. Jackson. Robert Moses and the Modern City: The Transformation of New York. New York: W.W. Norton \&, 2007.

Benevolo, Leonardo. History of Modern Architecture. Cambridge, MA: M.I.T., 1971.

Caro, RobertA. ThePowerBroker: RobertMosesandtheFall ofNewYork. New York:Vintage, 1975.

Choay, Françoise. The Modern City; Planning in the 19th Century. New York: G. Braziller, 1970.

Chriss, James J. Social Control: An Introduction. Cambridge, UK: Polity, 2007.

Clarke, John Henrik. Harlem, a Community in Transition. New York: Citadel, 1964.

Day, Jared N. Urban Castles: Tenement Housing and Landlord Activism in New York City 1890-1943. New York: Columbia UP, 1999.

Evans, Robin. "Rookeries and Model Dwellings." Architectural Association Quarterly 10.1 , 1978: 93-117.

Fishman, Robert. Urban Utopias in the Twentieth Century: Ebenezer Howard, Frank Lloyd Wright, and Le Corbusier. New York: Basic, 1977.

Frampton, Kenneth. Le Corbusier. New York: Thames \& Hudson, 2001.

Horowitz, Carl F. The New Garden Apartment: Current Market Realities of an American Housing Form. New Brunswick, NJ: Center for Urban Policy Research, 1983.

Koolhaas, Rem. Delirious New York: A Retroactive Manifesto for Manhattan. New York: Monacelli, 1994.

Kurshan, Virrginia. Sunnyside Garden Historic District. Rep. no. 3600. New York: New York City Landmarks Preservation Commission, 2007.

Lefaivre, Liane, Ingeborg Roode, and Rudolf Herman Fuchs. Aldo Van Eyck: The Playgrounds and the City. Amsterdam: Stedelijk Museum, 2002.

Lewis, David Levering. When Harlem Was in Vogue. New York: Knopf, 1981.

Loring, C.O. Stuyvesant Apartments. American Builder 2, 1869. 
Lubove, Roy. The Progressives and the Slums; Tenement House Reform in New York City, 1890-1917. Pittsburgh: University of Pittsburgh, 1963.

Marcus, Sharon. "Haussmanniztion as Anti-modernity: The Apartment House in Parisian Urban Discourse, 1850-1880

Marshall, Stephen. Streets \& Patterns. London: Spon, 2005.

Mumford, Eric. "The Tower in a Park in America: Theory and

Practice, 1920-1960." Planning Perspective 10.1 (1995).

Mumford, Lewis. The Sky Line, "Stuywesant Town Revisted." The New Yorker, November 27, 1948.

Ottley, Roi, and William J. Weatherby. The Negro in New York; an Informal Social History. New York: New York Public Library, 1967.

Plunz, Richard. A History of Housing in New York City: Dwelling Type and
Social Change in the American Metropolis. New York: Columbia UP, 1990.

Rosenburg, Charles E.. The Cholera Years. The United States in 1832,1849 , and 1866 . Chicago: University of Chicago Press, 1962.

Rowe, Peter G. Modernity and Housing. Cambridge, MA: MIT, 1993.

Sanjek, Roger. The Future of Us All: Race and Neighborhood
Politics in New York City. Ithaca: Cornell UP, 1998.

Stern, Robert A. M., Thomas Mellins, and David Fishman. New York 1880: Architecture and Urbanism in the Gilded Age. New York, NY: Monacelli, 1999.

Stern, Robert A. M., Gregory Gilmartin, and John Montague. Massengale. New York 1900: Metropolitan Architecture and Urbanism, 1890-1915. New York: Rizzoli, 1983.

Stern, Robert A. M., Thomas Mellins, and David Fishman. New York 1960: Architecture and Urbanism between the Second World War and the Bicentennial. New York, NY: Monacelli, 1995.

Thalen, Emily. NewUrbanism \& American Planning: The Conflict of Cultures. New York: Routledge, 2005.

Untermann, Richard K., and Lynn Lewicki. Accommodating the Pedestrian: Adapting Towns and Neighborhoods for Walking and Bicycling. New York: Van Nostrand Reinhold, 1984.

Urban, Florian. Tower and Slab: Histories of Global Mass Housing. Abingdon, Oxon: Routledge, 2012.

Wiebenson, Dora. Tony Garnier: The Cite Industrielle. New York: George Braziller, 1969.

Winnick, Louis. New People in Old Neighborhoods: The Role of New Immigrants in

Wright, Gwendolyn. Building the Dream: A Social History of Housing in America. New York: Pantheon, 1981.

Wright, Gwendolyn. USA: Modern Architecture in History. London: Reaktion, 2008. 